\title{
BUKU AJAR \\ ASUHAN KEBIDANAN PADA KEHAMILAN
}

\section{Penulis}

\author{
Hatijar, S.ST., M.Kes \\ Irma Suryani Saleh S.ST.,M.Kes, \\ Lilis Candra Yanti S.St .,M.Keb
}

Penerbit Cv. Cahaya Bintang Cemerlang

Anggota IKAPI 


\author{
BUKU AJAR \\ ASUHAN KEBIDANAN PADAKEHAMILAN \\ Penulis: \\ Hatijar, S.ST., M.Kes \\ Irma Suryani Saleh S.ST.,M.Kes, \\ Lilis Candra Yanti S.St .,M.Keb \\ ISBN 978-623-95446-9-0
}

Editor :

Muh. Yunus, S.Sos.,M.Kes

Penyunting:

Muh. Nur Fajrin

Putri Irmawati

Desain Sampul dan Tata Letak

Muh. Yunus Nabbi

Penerbit:

Percetakan CV. CAHAYA BINTANG CEMERLANG

Redaksi :

Jl. Dr. Wahidin Sudirohusodo BTN Indira Residence Blok E No. 10

Sungguminasa Kab. Gowa

No. HP: 085256649684

Email : muhyunusnabbi@gmail.com

Distributor Tunggal
Percetakan CV. CAHAYA BINTANG CEMERLANG

Jl. Dr. Wahidin Sudirohusodo BTN Indira Residence Blok E No. 10

Sungguminasa Kab. Gowa

No. HP: 085256649684/ WA: 085290480054

$\mathrm{http} / / \mathrm{cv}$-cahayabintangcemerlang.co.id

Anggota UMKM Nomor : 04933-0615-20

Anggota IKAPI Nomor : 027/SSL/2020

Cetakan Pertama, Desember 2020

Hak cipta dilindungi Undang-undang

Dilarang memperbanyak karya tulis ini dalam bentuk dan dengan cara Apapun tanpa ijin tertulis dari Penerbit 


\section{KATA PENGANTAR}

Angka kesakitan dan kesehatan ibu yang digambarkan melalui Angka Kematian Ibu (AKI) dapat menggambarkan status kesehatan ibu . Kematian ibu merupakan hal yang dapat diatasi dengan berbagai upaya untuk mencegah dan menangani komplikasi kelahiran

Berdasarkan Survei Demografi dan Kesehatan Indonesia tahun 2012, angka kematian ibu di Indonesia pada tahun 2012 yaitu sebesar 359 kasus per 100.000 kelahiran hidup. Sementara itu, Pemerintah Republik Indonesia menargetkan turunnya angka kematian ibu menjadi 306 kasus per 100.000 kelahiran hidup pada tahun 2019 Berdasarkan data Perserikatan Bangsa-Bangsa (PBB), angka kematian bayi di Indonesia pada 2019 lalu adalah 21,12. Angka ini menurun dari catatan pada 2018 ketika angka kematian bayi di Indonesia masih mencapai 21,86 atau pada 2017 yang mencapai 22,62 .

Nutrisi juga memiliki peran yang besar dalam menentukan kesehatan ibu. Malnutrisi ibu hamil tidak hanya berkaitan dengan malnutrisi pada janin yang sedang berkembang, namun juga secara langsung berpengaruh terhadap kesehatan ibu dan risiko kematian ibu. Riset menunjukkan bahwa ada dua jalur kritis dimana nutrisi ibu hamil dapat mempengaruhi kelangsungan hidup janin, yaitu anemia dan defisiensi kalsium. Anemia pada ibu hamil berkontribusi sebanyak 20\% dari kematian ibu.

Menurut WHO, dalam skala global,sebanyak 10\% ibu hamil dan $13 \%$ wanita yang baru saja melahirkan mengalami penyakit mental, terutama depresi. Khususnya negara-negara berkembang seperti Indonesia, angka kejadian penyakit mental pada ibu hamil lebih tinggi dari negara maju. Akan tetapi, kesadaran masyarakat terhadap isu ini masih sangat rendah.

Dalam rangka meningkatkan kemampuan mahasiswa dalam memberikan asuhan kebidanan pada ibu hamil, maka biasanya harus dimulai dalam proses pembelajaran didalam kelas sehingga teori dan praktek dilapangan dapat berjalan secara beriringan, oleh karena itu teori yang disusun berdasarkan kurikulum pembelajaran bagi mahasiswa program D III kebidanan. 
Dengan adanya buku ini diharapkan mahasiswa dapat mengaplikasikan ilmu yang telah dipelajari sehingga nantinya dapat menjalankan peran dan fungsinya di dalam masyarakat dalam rangka memberikan pelayanan kebidanan khususnya pada ibu hamil normal serta dapat mengenali secara dini adanya tanda bahaya dan komplikasi yang timbul. Dengan demikian dapat membantu menurunkan angka morbiditas dan mortalitas pada ibu hamil.

Berbagai teori dan keterampilan tentang ibu hamil normal yang dimasukkan kedalam buku ajar ini serta sudah disesuaikan dengan kurikulum yang ada yang terdiri dari 8 bab yang isinya antara lain Konsep dasar Asuhan kehamilan,Mendiagnosa Kehamilan, Faktor-faktor yang mempengaruhi kehamilan,Adaptasi fisiologi dan Psikologi dalam masa kehamilan,kebutuhan dasar ibu hamil sesuai tahap perkembagannya, Deteksi dini terhadap Komplikasi ibu dan janin,pendokumentsian Asuhan kebidanan serta asuhan kebidanan kehamilan.

Akhir kata,semoga dengan adanya buku ini dapat memberi banyak manfaat khususnya untuk mahasiswa/mahasiswi kebidanan maupaun keperawatan.

Poso, 2020

$\underline{\text { Penulis }}$ 


\section{DAFTAR ISI}

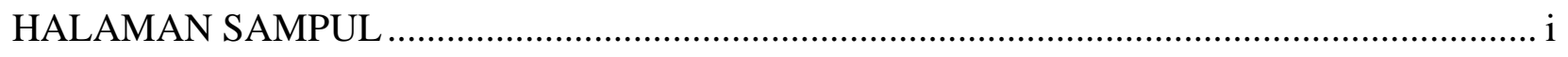

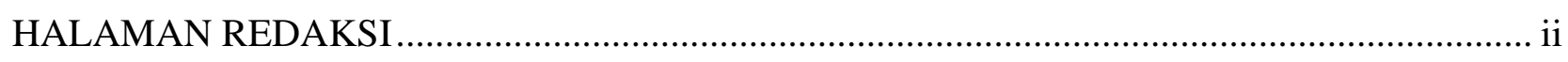

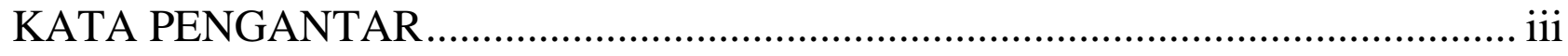

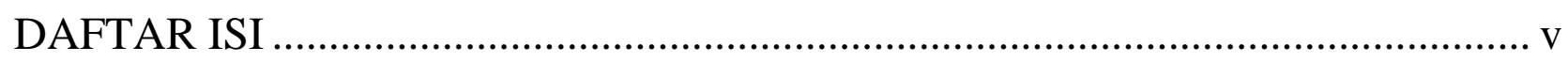

DESKRIPSI MATA KULIAH............................................................... ix

\section{BAB I KONSEP DASAR ASUHAN KEHAMILAN}
A. Konsep dasar Asuhan Kehamilan 1
B. Pengertian Konsep Dasar Asuhan Kehamilan ................................................. 1

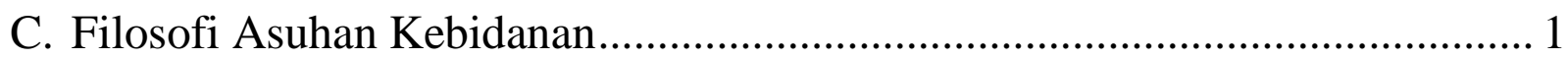
D. Lingkup Asuhan Kebidanan............................................................................. 4

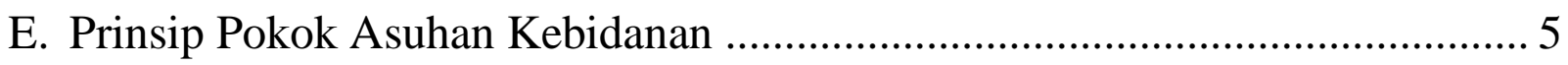

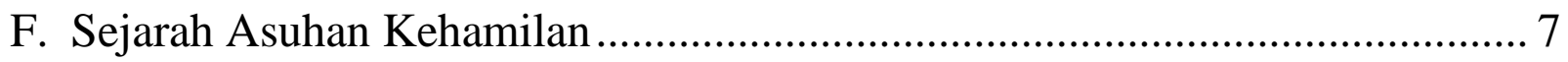

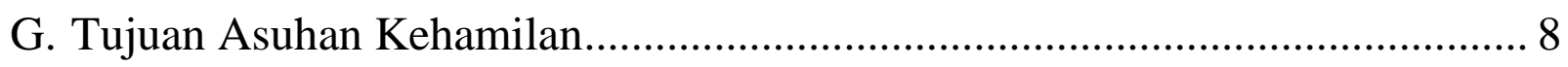

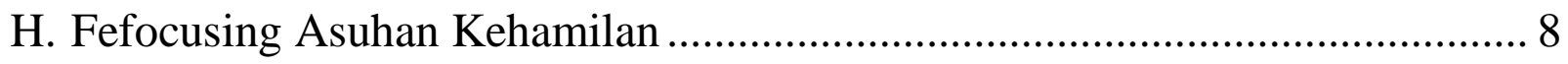

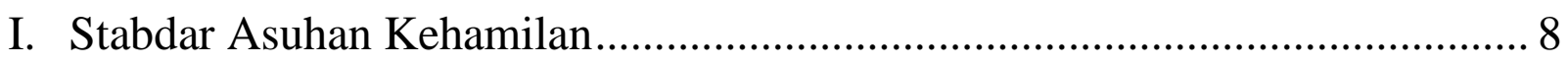

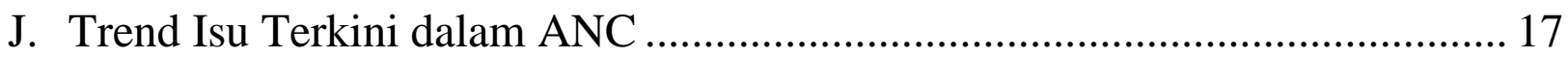
K. Evidence Base Dalam Praktek Kehamilan ........................................................ 19

\section{BAB II PROSES ADAPTASI FISIOLOGI DAN PSIKOLOGI DALAM MASA KEHAMILAN}

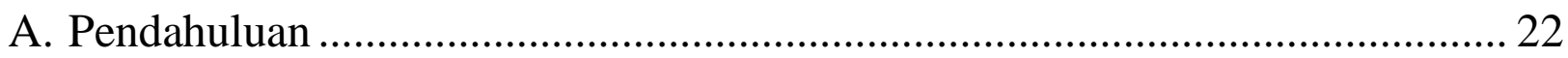

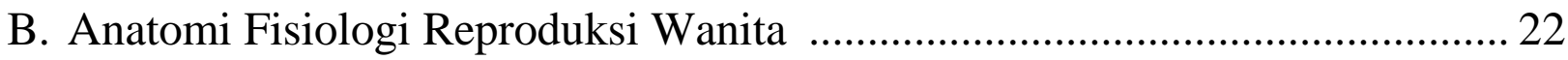

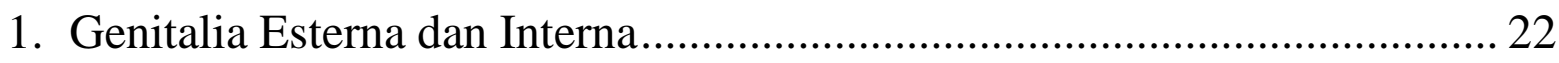

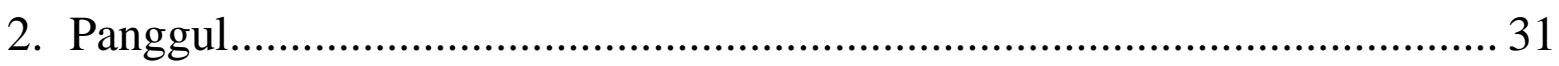

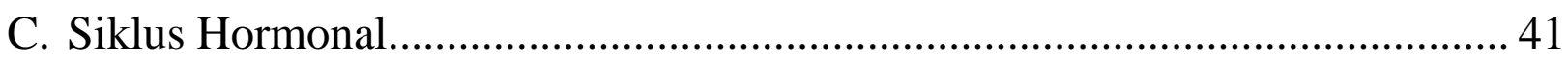

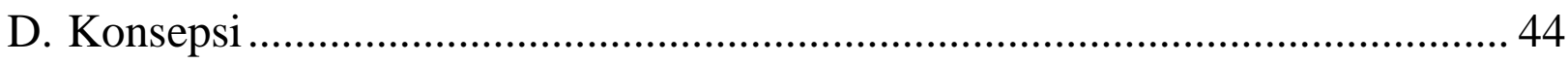

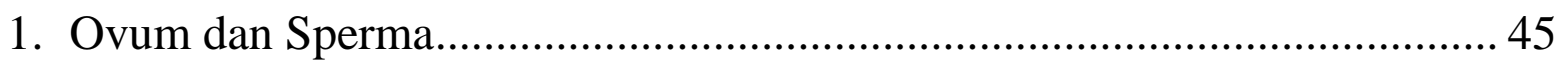

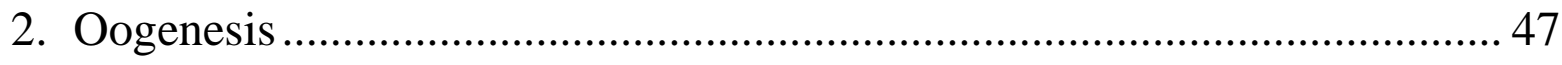

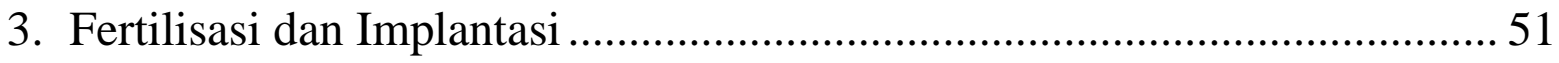

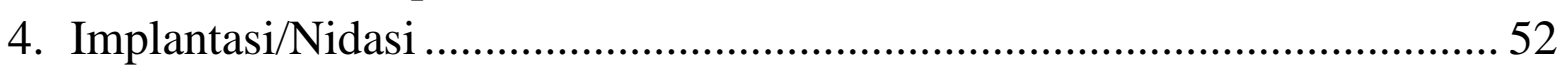

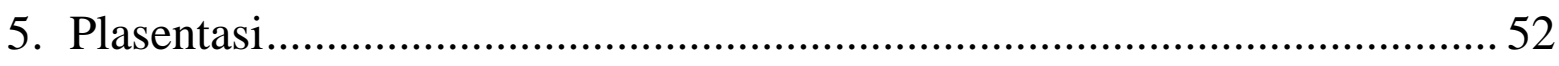

E. Pertumbuhan dan Perkembangan Konsepsi................................................... 53

1. Pertumbuhan dan perkembangan embrio ………....................................... 53

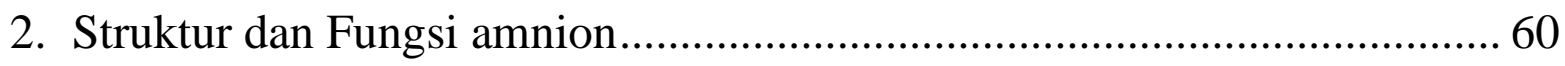




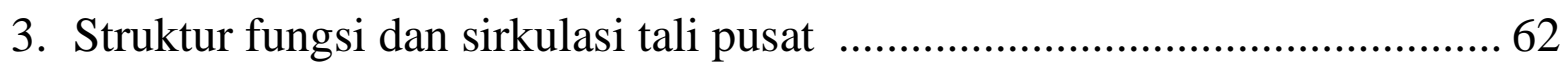

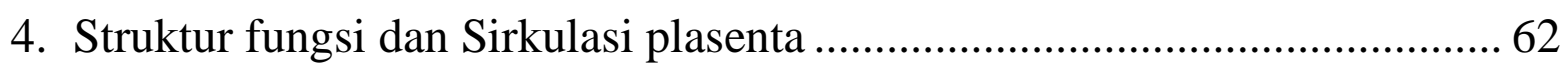

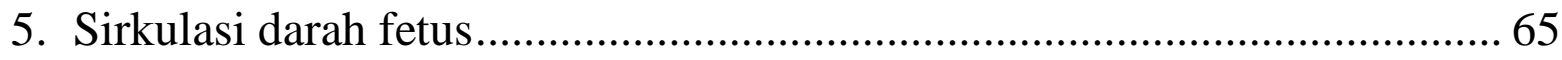

F. Perubahan Anatomi dan Adaptasi Fisiologi Pada Ibu Hamil Trimester

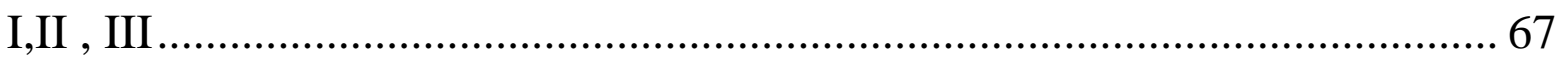

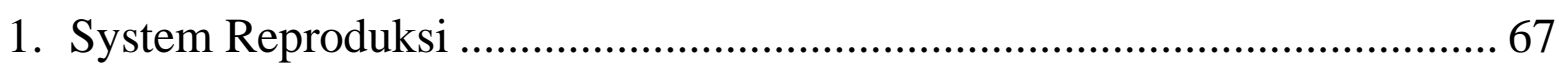

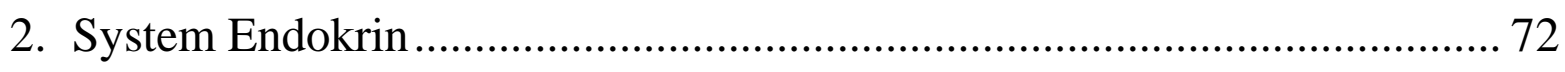

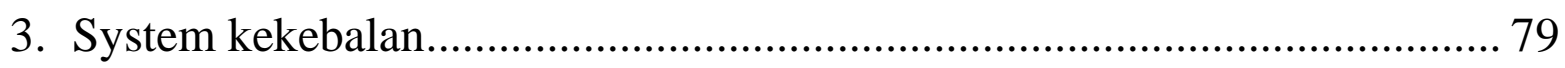

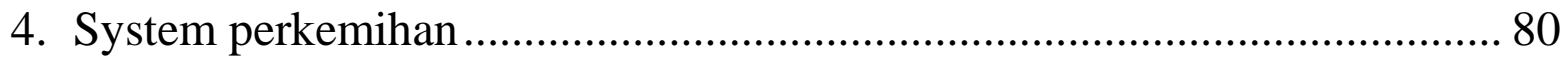

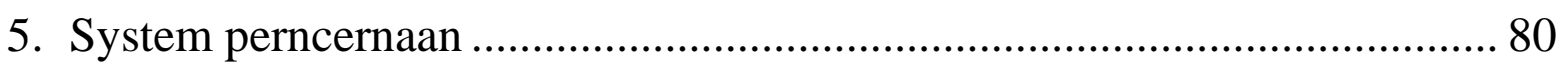

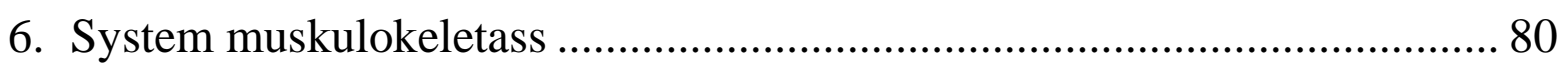

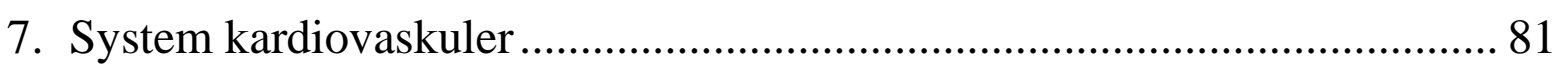

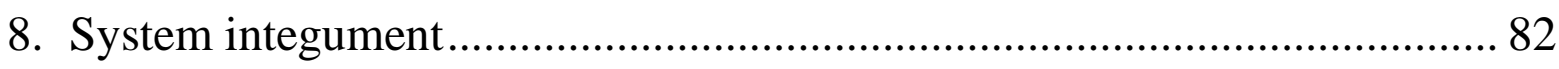

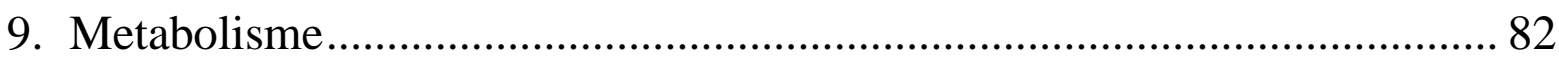

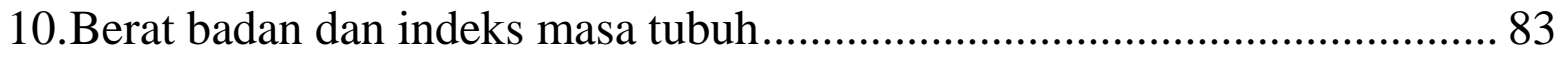

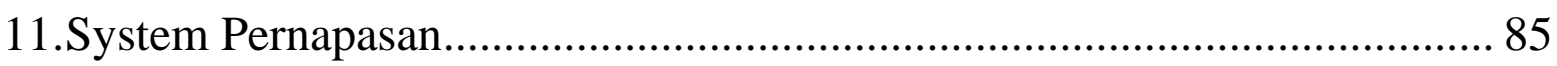

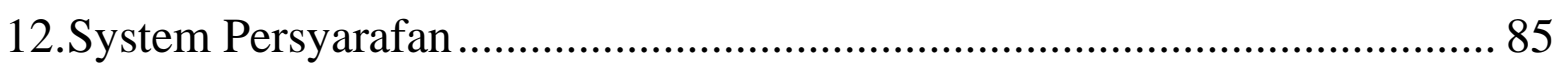

G. Perubahan dan aadaptasi Psikologi Dalam Masa Kehamilan .......................... 85

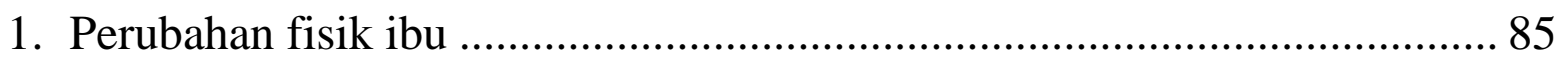

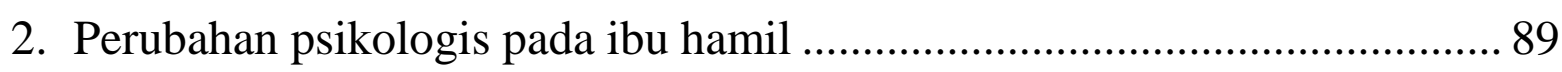

\section{BAB III MENDIAGNOSA KEHAMILAN}

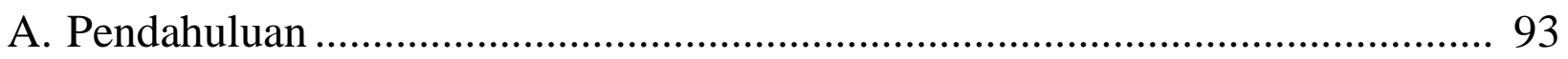

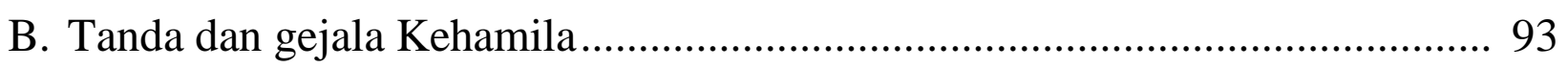

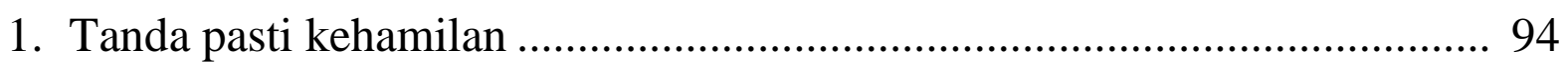

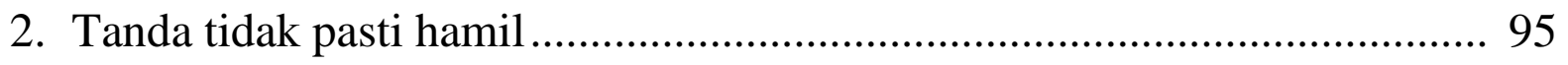

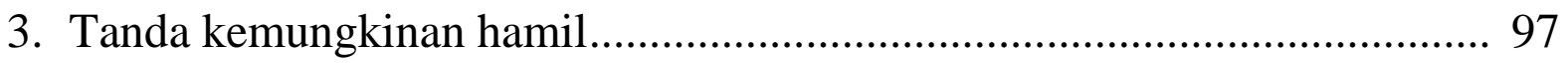

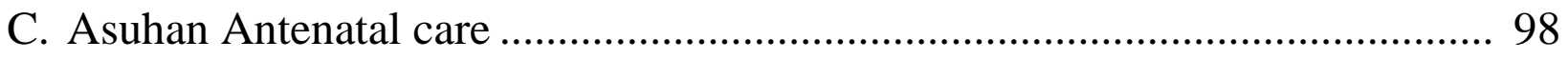

1. Pengertian Asuhan Antenatal care ......................................................... 98

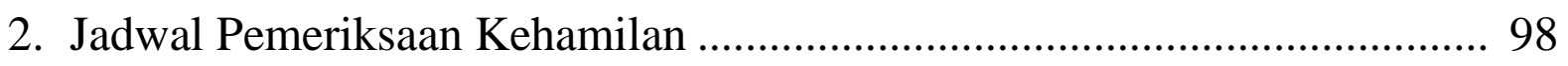

3. Pelayanan Asuhan Antenatal ................................................................ 99

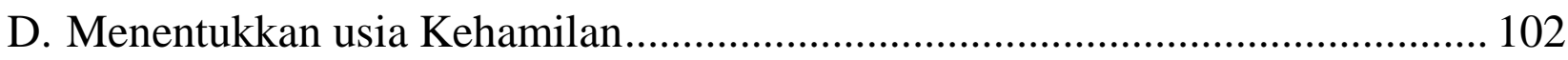

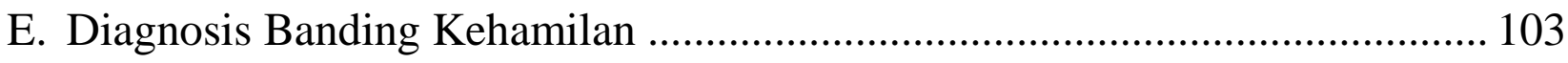

\section{BAB IV FAKTOR-FAKTOR YANG MEMPENGARUHI KEHAMILAN}

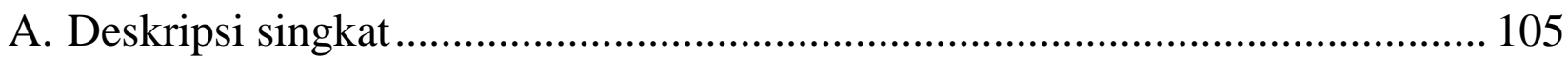

B. Faktor Fisik yang mempengaruhi Kehamilan................................................... 105

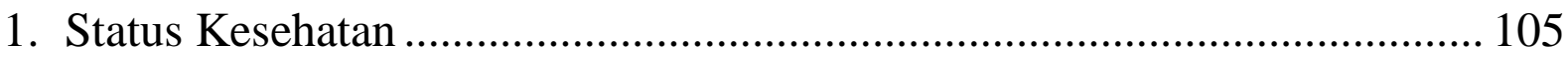




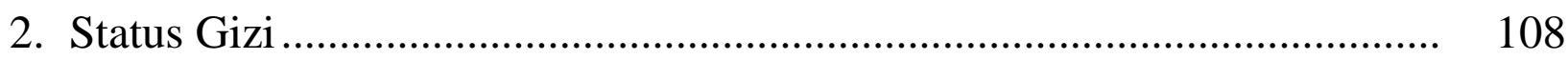

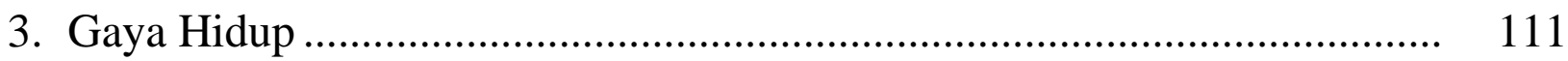

4. Substance Abuse ................................................................................. 112

5. Hamil Diluar Nikah........................................................................... 112

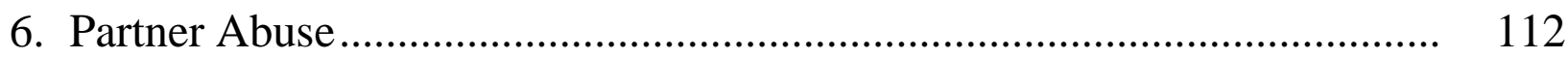

C. Faktor Psikologis............................................................................... 112

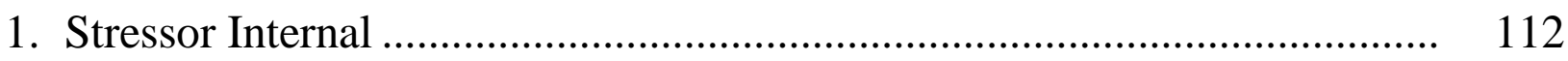

2. Stressor Eksternal............................................................................ 113

3. Dukungan Keluarga …........................................................................ 113

4. Kekerasan yang dilakukan pasangan (substance Abuse) ........................... 113

D. Faktor Lingkungan, Sosial Buaday,dan Ekonomi .......................................... 114

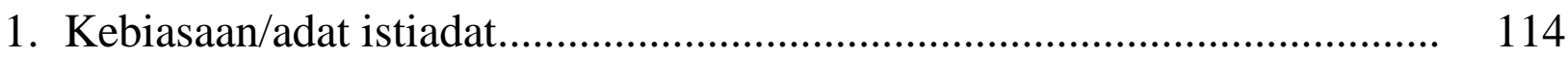

2. Fasilitas Kesehatan.................................................................... 114

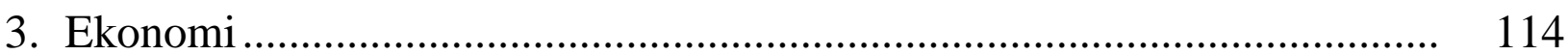

\section{BAB V KEBUTUHAN DASAR IBU HAMIL SESUAI DENGAN TAHAP PERKEMBANGANNYA}

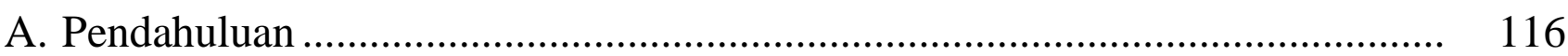

B. Kebutuhan Fisik Ibu Hamil Trimester I,II,III ............................................... 116

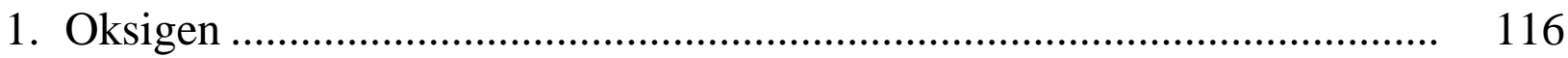

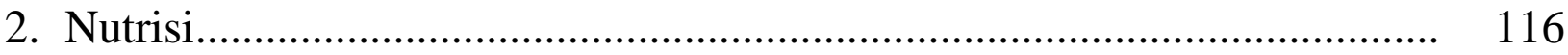

3. Personal Hygiene ……....................................................................... 119

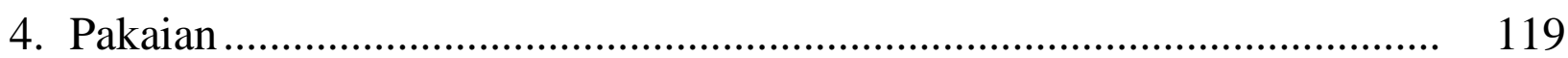

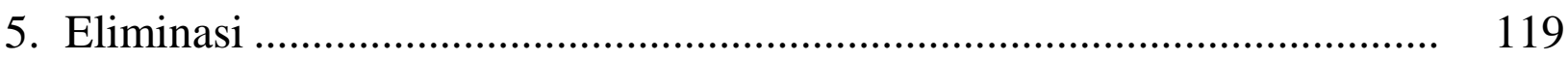

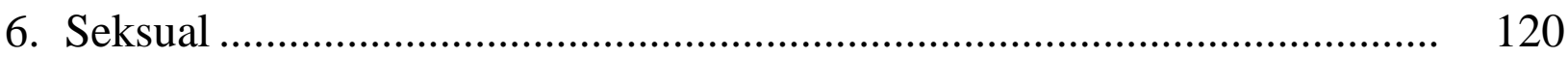

7. Mobilisasi/Body mekanik .................................................................... 121

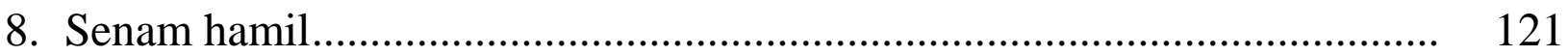

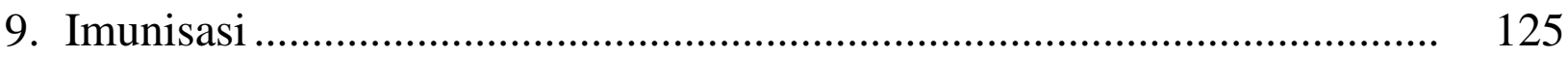

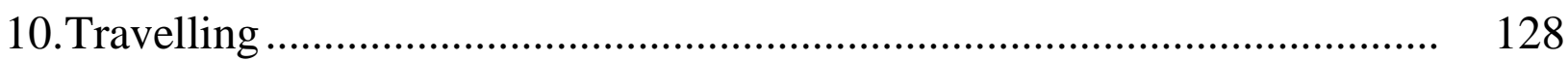

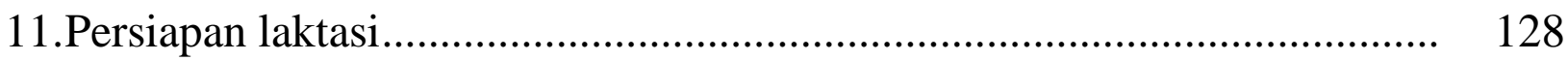

12.Persiapan persalinan dan kelahiran bayi ................................................. 129

C. Kebutuhan Psikologis Ibu hamil Trimester I,II,III ........................................ 148

1. Dukungan keluarga ................................................................................ 149

2. Dukungan Kesehatan ........................................................................ 149

3. Rasa aman dan nyaman selama kehamilan........................................... 150

4. Persiapan menjadi orang tua ............................................................ 150

5. Persiapan saudara kandung ................................................................... 150 


\section{BAB VI ASUHAN KEBIDANAN KEHAMILAN}

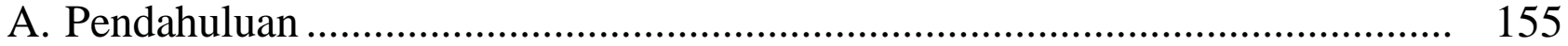

B. Asuhan Kehamilan kunjungan Awal ............................................................ 155

1. Tujuan Asuhan Antenatal .................................................................. 155

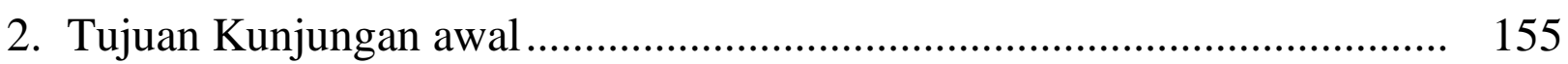

3. Pengkajian data ibu hamil/Anamnesis ................................................... 156

4. Isi riwayat pada kunjungan awal .......................................................... 156

C. Asuhan kehamilan Kunjungan Ulang ...................................................... 167

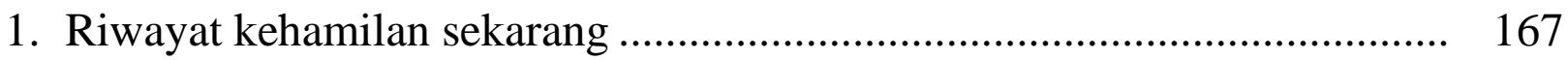

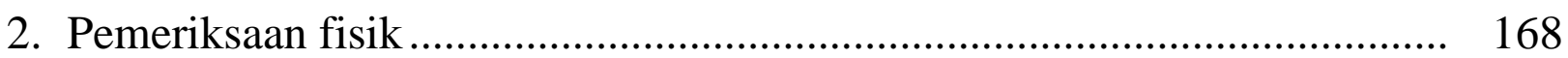

3. Pemeriksaan laboratorium ................................................................... 168

4. Pemberian suplemen,imunisasi dan konseling ........................................ 168

5. Pendokumentasian .......................................................................... 170

\section{BAB VII DETEKSI TERHADAP KOMPLIKASI IBU DAN JANIN}

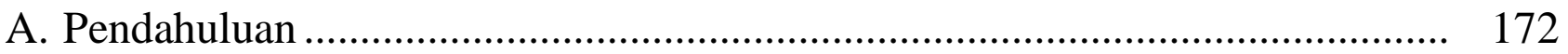

B. Tanda-tanda dini bahaya/komplikasi Ibu dan janin Masa kehamilan Muda198 172

1. Perdarahan Pervaginam ..................................................................... 172

2. Hipertensi Dalam Kehamilan.............................................................. 181

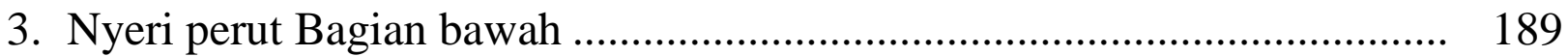

C. Tanda dini bahaya /komplikasi pada kehamilan lanjut................................... 190

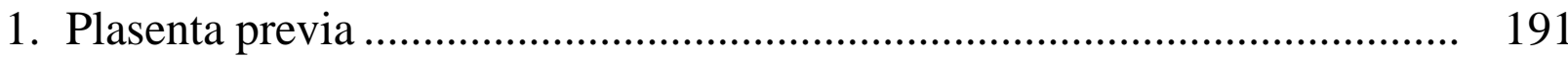

2. Solusio plasenta …........................................................................... 194

\section{BAB VIII PENDOKUMENTASIAN ASUHAN KEHAMILAN}

A. Pendahuluan

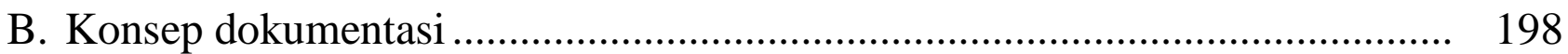

C. Model-model Dokumentasi Asuhan ……................................................... 198

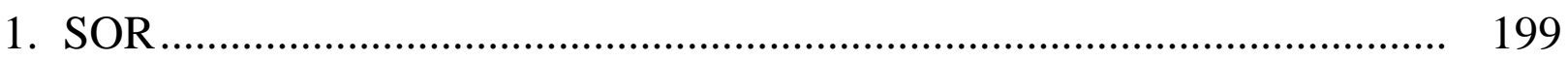

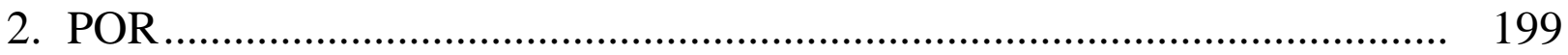

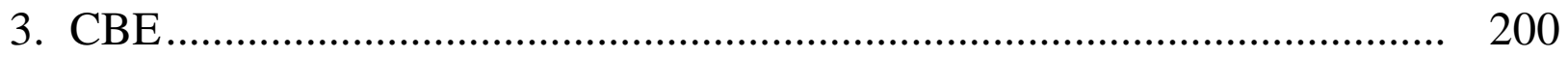

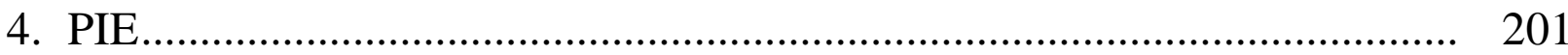

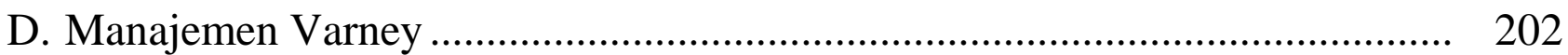

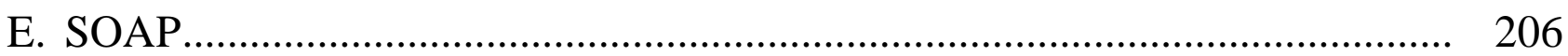

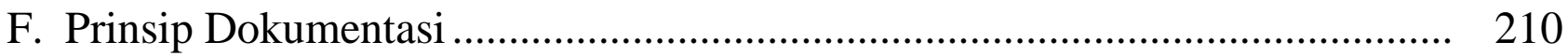

G. Biografi Penulis...................................................................................... 214 


\section{PENGANTAR ASUHAN KEBIDANAN KEHAMILAN}

\section{A. DESKRIPSI MATA KULIAH}

Mata kuliah ini memberikan kemampuan kepada mahasiswa untuk memberikan asuhan kebidanan pada ibu hamil normal dengan memperhatikan aspek budaya yang didasari konsep-konsep, sikap dan keterampilan serta hasil evidence based dalam praktek antenatal yang menggunakan pendekatan manajemen kebidanan yang berfokus pada upaya preventif dan promotif, deteksi dini dan komplikasi serta pendokumentasiannya.

\section{B. MANFAAT MATA KULIAH}

Mata kuliah ini merupakan pengetahuan dasar yang mendukung peran dan funsi bidan dalam memberikan asuhan pada kehamilan normal. Mata kuliah ini memberi panduan pada bidan dalam membantu dan mempersiapkan ibu dan keluarga dalam menjalani kehamilannya dengan normal, mendeteksi dini adanya kelainan selama kehamilan. Dengan memahami secara tepat mata kuliah ini akan sangat membantu bidan dalam menurunkan angka kesakitan dan kematian ibu hamil.

\section{KOMPETENSI DASAR}

1. Memahami konsep dasar asuhan kehamilan

2. Memahami proses adaptasi fisiologis dan psikologis dalam masa kehamilan

3. Memahami mendiagnosa kehamilan

4. Memahami faktor-faktor yang mempangaruhi kehamilan

5. Mengidentifikasi kebutuhan dasar ibu hamil sesuai dengan tahap perkembangannya

6. Memberikan asuhan kehamilan 
7. Memahami deteksi dini terhadap komplikasi ibu dan janin

8. Melakukan pendokumentasian asuhan kehamilan

\section{STRATEGI PERKULIAHAN}

Metode perkuliahan yang digunakan adalah kombinasi antara ceramah, diskusi dab praktek laboratorium. Setelah dijelaskan mengenai teoriteori yang relevan selanjutnya diadakan diskusi, dimana dalam diskusi tersebut dapat diharapkan adanya umpan balik dari mahasiswa yang mengikuti perkuliahan dan selanjutnya materi yang telah didiskusikan dilanjutkan dengan praktek dilaboratorium sesuai dengan materi selanjutnya.

\section{E. SUMBER KEPUSTAKAAN}

1. Prawirohardjo, Sarwono. 2002. Buku Panduan Praktis Pelayanan Kesehatan Maternal dan Neonatal, Yayasan Bina Pustaka : Jakarta.

2. Varney, Helen. 2006. Asuhan Kebidanan Edisi 4. EGC : Jakarta.

3. Manuaba. 1998. Ilmu Kebidanan, Penyakit Kandungan dan KB. EGC : Jakarta.

4. Manuaba,Ida Bagus,dkk.2010. Ilmu Kebidanan,Penyakit Kandungan dan KB,Jakarta:EGC

5. Saifuddin, dkk. 2002. Buku Panduan Praktis Pelayanan Kesehatan Maternal dan Neonatal. YBPSP : Jakarta.

6. Sulistyawati. A. 2009. Asuhan Kebidanan Pada Masa Kehamilan. Jakarta: Salemba Medika

7. Ai Yeyeh, Rukiyah dkk. Asuhan Kebidanan I ( Kehamilan ). Cetakan Pertama. Jakarta: Trans Info Media; 2009 
8. Prawirohardjo S. 2007. Ilmu Kandungan. Jakarta: Yayasan Bina Pustaka Sarwono Prawirohardjo

9. Saifudin, AB, 2006. Buku Acuan Nasional Pelayanan Kesehatan Maternal dan Neonatal. Jakarta: Yayasan Pustaka Sarwono Prawirohardjo

10. Salmah, dkk. 2006. Asuhan kebidanan antenatal. Jakarta: EGC

11. Sulistyawati, A. 2009. Asuhan Kebidanan Pada Masa Kehamilan. Jakarta; Salemba Medika

12. Marmi, S.S T. 2011. Asuhan Kebidanan pada Masa Antenatal. Yogyakarta. Pustaka Pelajar

13. Walyani, Elisabeth Siwi. 2014. Asuhan Kebidanan pada Kehamilan. Yogyakarta; Pustaka Baru Press.

14. Wylie,Linda,2011. Esensial Anatomi dan Fisiologi Dalam Asuhan Maternitas,Jakarta:EGC 


\section{BAB I}

\section{KONSEP DASAR ASUHAN KEHAMILAN}

\section{A. PENDAHULUAN}

1. Deskripsi singkat

Dalam pokok bahasan ini di bahas tentang konsep dasar asuhan kehamilan meliputi philosofi asuhan kehamilan, lingkup asuhan kehamilan, prinsip pokok asuhan kehamilan, sejarah auhan kehamilan, tujuan asuhan kehamilan, refocusing asuhan kehamilan dan standar asuhan kehamilan.

2. Tujuan Intruksional Khusus (TUK)

Setelah mengikuti mata kuliah ini mahasiswa mampu menjelaskan dan memahami konsep dasar asuhan kehamilan.

\section{B. PENGERTIAN KONSEP DASAR ASUHAN KEHAMILAN}

Konsep merupakan penjelasan mengenai teori yang telah di uji melalui observasi/penelitian. Asuhan kehamilan merupakan pedoman kerangka kerja bidan dalam memberikan asuhan kehamilan yang beriorentasi pada ibu dan janin.

\section{PHILOSOFI ASUHAN KEHAMILAN}

1. Filosofi Asuhan Kehamilan

Kata Philosofi berasal dari kata philo yang artinya cinta dan sophia yang berarti kebijaksanaan. Philosofi asuhan kehamilan meruapakan disiplin ilmu yang difokuskan pada pencarian dasardasar dan penjelasan yang nyata mengenai penerapan fungsi dan tanggung jawab dalam meberikan pelayanan pada klien yang mempunyai kebutuhan atau masalah. Proses kehamilan merupakan proses normal dan alamiah. Hal ini perlu diyakini oleh tenaga 
kesehatan khususnya bidan, sehingga dalam memberikan asuhan kepada pasien, pendekatan yang dilakukan cenderung dalam bentuk pelayanan promotif. Realisasi yang paling mudah dilaksanakan adalah pelaksanaan komunikasi informasi dan edukasi (KIE) kepada pasien dengan materi-materi mengenai pemantauan kesehatan ibu hamil dan penatalaksanaan ketidaknyamanan selama hamil.

Dalam filosofi asuhan kehamilan ini dijelaskan beberapa keyakinan yang akan mewarnai asuhan tersebut :

a. Kehamilan merupakan proses yang alamiah. Perubahanperubahan yang terjadi selama kehamilan normal adalah bersifat fisiologis bukan patologis. Oleh karenanya asuhan yang diberikan adalah asuhan yang meminimalkan intervensi. Bidan harus memfasilitasi proses alamiah dari kehamilan dan menghindari tindakan-tindakan yang bersifat medis yang tidak terbukti manfaatnya.

Dalam memberikan perawatan selama masa kehamilan, perlu diperhatikan fokus philosofi yang tekait, antara lain :

1. Memperhatikan keamanan klien (safety)

2. Memperhatikan kepuasaan klien (satisfying)

3. Menghormati martabat manusia dan self determination

4. Menghormati perbedaan kultur dan etik (respecting cultural and ethics diversity

5. Berpusat pada konteks keluarga (family centered)

6. Berorientasi pada promosi kesehatan (health promotion) 
7. Penatalaksaaan perawatan wanita hamil, sebagaimna pada semua aspek pada siklus usia subur melibatkan prinsipprinsip dasar philosofi kebidanan.

b. Asuhan kehamilan mengutamakan kesinambungan pelayanan (continuity of care) sangat penting bagi wanita untuk mendapatkan pelayanan dari seorang professional yang sama atau dari satu team kecil tenaga professional, sebab dengan begitu maka perkembangan kondisi mereka setiap saat akan terpantau dengan baik selain juga mereka menjadi lebihpercaya dan terbuka karena merasa sudah mengenal si pemberi asuhan.

c. Pelayanan yang terpusat pada wanita (women centered) serta keluarga (family centered)

Wanita (ibu) menjadi pusat asuhan kebidanan dalam arti bahwa asuhan yang diberikan harus berdasarkan pada kebutuhan ibu,bukan kebutuhan dan kepentingan bidan. Asuhan yang diberikan heendaknya tidak hanya melibatkan ibu hamil saja melainkan juga keluarganya, dan itu sangat penting bagi ibu sebab keluarga menjadi bagian integral/tak terpisahkan dari ibu hamil. Sikap,perilaku dan kebiasaan ibu hamil juga akan mempengaruhi seluruh anggota keluarga. Selain itu,keluarga juga merupakan unit social yang terdekat dan dapat memberikan dukungan yang kuat bagi anggotanya. Dalam pengambilan keputusan haruslah merupakan kesepakatan bersama antara ibu, keluarganya, dan bidan, dengan ibu sebagai penentu utama dalam proses pengambilan keputusan. Ibu mempunyai hak untuk 
memilih dan memutuskan kepada siapa dan dimana akan memperoleh pelayanan kebidananannya.

d. Asuhan kehamilan menghargai hak ibu hamil untuk berpartisipasi dan memperoleh pengetahuan/pengalaman yang berhubungan dengan kehamilannya. Tenaga professional kesehatan tidak mungkin terus menerus mendampingi dan merawat ibu hamil, karenanya ibu hamil perlu mendapat informasi dan pengalaman agar dapat merawat diri sendiri secara benar.

\section{LINGKUP ASUHAN KEHAMILAN}

Kebidanan adalah profesi yang diakui secara internasional yang memiliki praktisi diseluruh dunia. Bidan dapat melakukan praktek di Rumah sakit, klinik, unit kesehatan atau layanan kesehatan lainnya.

1. Keterampilan Dasar

Keterampilan ini merupakan keahlian yang wajib dimiliki oleh bidan untuk bias

mengasuh dengan baik. Berikut keterampilan yang dimaksud :

a. Mengumpulkan pemeriksaan fisik

b. Melakukan pemeriksaan fisik

c. Menilai keadaan janin

d. Menghitung usia kehamilan dan hari perkiraan lahir (HPL)

e. Mengkaji status nutrisi

f. Mengkaji kenaikan berat badan

g. Memberikan penyuluhan

h. Penatalaksanaan pada anemia ringan, hipertensi gravidarum tingkat I,abortus iminen dan pre eklamsia ringan 
i. Memberi imunisasi.

2. Keterampilan tambahan

Selain keterampilan dasar akan sangat membantu bila bidan juga memiliki bekal keterampilan yaitu:

a. Menggunakan dopler

b. Memberikan pengobatan

c. Melakukan Long Life Skill ( LLS) dalam manajemen pasca aborsi.

\section{E. PRINSIP POKOK ASUHAN KEHAMILAN}

Prinsip yang seharusnya dilakukan oleh bidan selama melakukan asuhan kehamilan adalah sebagai berikut

1. Kehamilan dan kelahiran adalah suatu proses yang normal alami dan sehat.

Sebagai bidan, kita meyakini bahwa model asuhan kehamilan yang membantu serta melindungi proses kehamilan dan kelahiran normal adalah yang paling penting sesuai bagi sebagian besar wanita. Tidak perlu melakukan intervensi yang tidak didukung oleh bukti ilmiah (evidence Based Practice)

2. Menjaga kerahasiaan dan privacy pasien

3. Membantu klien merasa nyaman dan aman serta memberikan dukungan emosional

4.Pemberdayaan

Ibu adalah pelaku utama dalam asuhan kehamilan. Oleh karena itu bidan harus memberdayakan ibu (dan keluarga) dengan meningkatkan pengetahuan dan pengalaman mereka melalui pendidikan kesehatan 
agar dapat merawat dan menolong diri sendiri pada kondisi tertentu. Hindarkan sikap negative dan banyak mengkritik.

\section{Otonomi}

Pengambil keputusaan adalah ibu dan keluarga. Untuk dapat mengambil suatu keputusan mereka memerlukan informasi. Bidan harus memberikan informasi yang akurat tentang risiko dan manfaat dari semua prosedur, obat-obatanmaupun tes/pemeriksaan sebelum mereka memutuskan untuk menyetujuinya . bidan juga harus membantu ibu dalam membuat suatu keputusan tentang apa yang terbaik bagi ibu dan bayinya berdasarkan system nilai dan kepercayaan ibu/keluarga.

6. Tidak membahayakan

Intervensi harus dilaksanakan atas dasar indikasi yang spesifik, bukan sebagai rutinitas tes-tes rutin, obat atau prosedur lain pada kehamilan yang dapat membahayakan ibu maupun janin. Bidan yang terampil harus mengetahui kapan ia harus melakukan asuhan sesuatu dan intervensi yang dilakukannya haruslah aman berdasarkan bukti ilmiah.

7. Tanggung Jawab

Asuhan kehamilan yang diberikan bidan harus selalu didasari ilmu,analisis dan pertimbangan yang matang. Akibat yang timbul dari tindakan yang dilakukan menjadi tanggungan bidan. Pelayanan yang diberikan harus bersarakan kebutuhan ibu dan janin bukan atas kebutuhan bidan. Asuhan yang berkualitas berfokus pada klien dan saying ibu serta berdasarkan bukti ilmiah terkini (praktek terbaik) menjadi tanggung jawab semua professional bidan. 


\section{F. SEJARAH ASUHAN KEHAMILAN}

Kebidanan merupakan ilmu yang sama tuanya dengan homo sapienns. Istilah bidan di Yahudi merupakan bidan petama yang ditemukan, sesuai dengan maknanya yang berkenaan dengan wanita. Pada abad ke 18 para wanita tua seringkali menurunkan ilmu kebidanan yang mereka miliki kepada anak perempuanny, mereka juga tidak berpendidikan, mereka belajar dari pengalaman dan sangat mengandalkan kesbaran, obat-obatan rumah dan doa karena hal tersebut meruapakan sumber yang dapat digunakan membantu wanita melahirkan, tanpa lisensi, organisasi dan program pendidikan formal.

Pada tahun 1950 di buka kursus kebidanan di bawa oleh seorang bidan VOC untuk meringankan penderitan masyarakat pribumi. Siswa pendidikan bidan diambil dari tenaga para juru rawat yang telah bekerja selama 3 tahun untuk mendapat pendidikan selama 2 tahun dan ditetapkan menjadi pembantu bidan. Kongres Vereniging Van Geneeskundingen di Semarang tahun 1938 dengan tegas menolak bentuk pembantu bidan dan mengkhendaki didirikan sekolah bidan. Dokter M. Toha setelah menamatkan sebagai ahli kebidanan dan penyakit kandungan di Cirebon mendapatkan kesempatan untuk mengutarakan berbagai masalah dalam bidang pelayanan kebidanan dan selanjutnya Prof. Remmeltz meluluskan permintaan mendirikan sekolah bidan untuk pertama kalinya.

Dalam pidato pembukaan "World Congress On Human Reproduction" Nusa Dua Bali tanggal 4-9 April 1994, presiden Soeharto menyampaikan akan menyebarkan 50.000 bidan di desa. Diharapkan dapat menggantikan peranan dukun untuk memberikan 
pertolongan persalinan legalitas dan melakukan penapisan bagi kelompok kehamilan dengan resiko tinggi.

\section{G. TUJUAN ASUHAN KEHAMILAN}

Pada umumnya kehamilan berkembang secara normal dan menghasilkan kelahiran bayi yang sehat, cukup bulan, melalui jalan lahir, namun kadang-kadang tidak sesuai dengan yang diharapkan. Oleh karena itu pelayanan asuhan antenatal merupakan cara penting utnuk memonitor dan mendukung kesehatan ibu hamil normal dan mendeteksi ibu dengan kehamilan normal.

1. Memantau kemajuan kehamilan, memastikan kesehatan ibu dan tumbuh kembang bayi

2. Meningkatkan dan mempertahankan kesehatan fisik, mental serta social dan bayi

3. Menemukan sejak dini bila ada masalah atau gangguan dan komplikasi yang mungkin terjadi selama kehamilan

4. Mempersiapkan kehamilan dan persalinan dengan selamat baik ibu maupun bayi, dengan trauma seminimal mungkin

5. Mempersiapkan ibu agar masa nifas dan pemberian ASI ekslusif berjalan normal

6. Mempersipkan peran ibu dan keluarga dapat berperan dengan baik dalam memelihara bayi agar dapat tumbuh kembang secara normal.

\section{H. FEFOCUSING ASUHAN KEHAMILAN}

Pemfokusan asuhan antenatal rutin merupakan peran asuhan antenatal dalam mempromosikan kelangsungan hidup ibu dan bayi baru lahir secara logis merupakan hal yang sangat rumit karena ada begitu 
banyak gagal dalam lingkungannya yang saling berinteraksi untuk mempengaruhi efektifitas dari asuhan tersebut.

1. Trimester pertama/sebelum mingu ke 14

a. Membina hubungan saling percaya antara bidan dan ibu sehingga mata rantai penyelamatan jiwa telah terbina jika diperlukan

b. Mendeteksi masalah yang dapat diobati sebelum mengancam jiwa ibu maupun bayi.

c. Mencegah masalah seperti tetanus neonatorum, anemia defisiensi zat besi maupun penggunaan praktik tradisional yang merugikan

d.Memulai persiapan persalinan dan kesiapan menghadapi komplikasi

e. Mendorong perilaku yang sehat (mutrisi, latihan dan kebersihan, istrahat)

2. Trimester kedua/sebelum minggu ke 28

a. Membina hubungan saling percaya antara bidan dan ibu sehingga suatu mata rantai penyelamatan jiwa telah terbina jika diperlukan

b.Mendeteksi masalah seperti yang dapat diobati sebelum mengancam jiwa

c. Memulai persiapan persalinan dan kesiapan menghadapi komplikasi

d.Mendorong perilaku yang sehat (nutrisi, latihan dan kebersihan, istrahat)

e. Mencegah masalah seperti tetanus neonatorum, anemia defisiensi zat besi, maupun penggunaan praktik tradisional yang merugikan

f. Kewaspadaan khusu mengenai PIH (Tanya ibu mengenai gejala $\mathrm{PIH}$, pantau tekanan darahnya,edema,proteinuria) 
3. Trimester ketiga/sebelum minggu ke 40

a. Membina hubungan saling percaya antara bidan dan ibu sehingga suatu mata rantai penyelamatan jiwa telah terbina jika diperlukan

b. Mendeteksi masalah yang dapat diobati sebelum menjadi bersifat mengancam jiwa

c. Mencegah masalah seperti tetanus neonatorum, anemia, defisiensi zat besi, penggunaan praktik tradisional yang merugikan

d.Memulai persiapan persalinan dan kesipana menghadapi komplikasi

e. Mendorong perilaku yang sehat \{nutrisi,latihan dan kebersihan)

f. Kewaspadaan khusu mengenai PIH (Tanya ibu mengenai gejala PIH, pantau tekanan darahnya,edema,proteinuria).

\section{Focus lama ANC adalah sebagai berikut}

1. Mengumpulkan data dalam upaya mengidentifikasi ibu yang beresiko tinggi dan merujuknya untuk mendapatkan asuhan khusus

2. Temuan-temuan fisik (TB, BB, ukuran pelvis,edema kaki, Posisi, Presentase janin dibawah usia 36 minggu) yang memperkirakan kategori risiko $\mathrm{ibu}$

3.Pengajaran/pendidikan kesehatan yang ditujukan untuk mencegah risiko/komplikasi.

\section{Isi Refocusing ANC}

Sebagaimana ditunjukkan oleh berbagai penelitian di seluruh dunia, untuk lebih bias efektif dalam meningkatkan keselamatan ibu dan bayi baru lahir maka asuhan antenatal harus difokuskan pada intervensi yang 
telah terbukti bermanfaat menurunkan angka kesakitan dan kematian ibu serta bayi baru lahir.

Penolong yang terampil /terlatih harus selalu tersedia untuk hal-hal berikut :

1. Membantu setiap ibu hamil dan keluarganya untuk membuat perencanaan persalinan yaitu petugas kesehatan yang terampil, tempat bersalin,keuangan,nutrisi yang baik selama kehamilan, serta perlengkapan esensial untuk ibu-bayi. Penolong persalinan yang terampil menjain asuhan normal yang aman sehingga mencegah komplikasi yang mengancam jiwa, serta dapat segera mengenal masalah dan merespons dengan tepat.

2. Membantu setiap ibu hamil dan keluarganya dalam mempersiapkan diri menghadapi komplikasi (deteksi dini, menentukkan orang yang akan membuat keputusan, dana kegawatdaruratan, komunikasi,transportasi dan donor darah pada setiap kunjungan. Jika setiap ibu hamil sudah mempersiapkan disi sebelum terjadi komplikasi maka waktu penyelamatan jiwa tidak akan banyak terbuang untuk membuat keputusan, mencari transportasi, biaya,donor darah.

3. Melakukan skrining/penapisan kondisi-kondisi yang memerlukan persalinan RS (riwayat SC, IUFD). Ibu yang sudah tahu bahwa ia mempunyai kondisi yang memerlukan kelahiran di RS akan berada di RS saat persalinan sehingga kematian karena penundaan keputusan yang kurang tepat atau hambatan dalam hal jangkauan akan dapat dicegah. 
4. Mendeteksi dan menangani komplikasi (preeklamsia, perdarahan pervaginam, anemia berat, penyakit menular seksual, tuberkulosisi, malaria dan sebagainya).

5. Mendeteksi kehamilan ganda setelah usia 28 minggu dan letak presentasi abnormal setelah 36 minggu. Ibu yang memerlukan kelahiran operasi akan sudah mempunyai jangkauan pada penolong yang terampil dan fasilitas kesehatan yang dibutuhkan

6. Memberikan imunisasi Tetanus Toxoid untuk mencegah kematian BBL karena tetanus.

7. Memberikan suplementasi zat besi dan asam folat. Umumnya anemia ringan yang terjadi pada ibu hamil adalah defisiensi zat besi dan asam folat.

Untuk populasi tertentu.

a.Profilaksis care tambang(penanganan promotif) untuk menurunkan insiden anemia berat

b.Pencegahan/terapi preventif malaria untuk menurunkan risko terkena Malaria di daerah endemic

c.Suplementasi yodium

d.Suplementasi vitamin A

\section{STANDAR ASUHAN KEHAMILAN}

1. Pelayanan kebidanan meliputi 24 standar yang dapat dikelompokkan sebagai berikut :
a. Standar pelayanan umum (2 standar)
b. Standar pelayanan antenatal (6 standar)
c. Standar pertolongan persalinan (4 standar)
d. Standar pelayanan nifas (3 standar) 
e. Standar penanganan kegawatdaruratan obstetric neonatal (9 standar)

Terdapat enam standar dalam standar pelayanan asuhan antenatal. Standar tersebut merupakan bagian dari lingkup standar pelayanan kebidanan.

\section{Standar I. Identifikasi Ibu Hamil}

Bidan melakukan kunjungan rumah dan berinteraksi dengan masyarakat secara berkala untuk memberikan penyuluhan dan memotivasi ibu, suami dan anggota keluarganya agar mendorong ibu untuk memeriksakan kehamilannya sejak dini secara teratur.

\section{Standar 2. Pemeriksaan dan Pemantauan Antenatal}

Bidan memberikan sedikitnya 4 kali pelayanan antenatal . pemeriksaan meliputi anamnesis serta pemantauan ibu dan janin dengan saksama untuk menilai apakah perkembangan berlangsung normal. Bidan juga harus mengenal kehamilan risiko tinggi khususnya anemia, kurang gizi, hipertesi, PMS/infeksi HIV, memberikan pelayanan imunisasi,nasihat dan penyuluhan kesehatan serta tugas terkait lainnya yang diberikan oleh puskesmas. Mereka harus mampu mengambil tindakan yang diperlukan dan merujuknya untuk tindakan selanjutnya.

\section{Standar 3. Palpasi Abdominal}

Bidan melakukan pemeriksaan abdominal secara seksama dan melakukan palpasi untuk memperkirakan usia kehamilan bila umur kehamilan bertambah, memeriksa posisi, bagian terendah janin dan 
masukanya kepala janin ke dalam rongga panggul untuk mencari kelainan serta melakukan rujukan tepat waktu

\section{Standar 4.Pengelolaan Anemia}

Bidan melakukan tindakan pencegahan,penemuan, penanganan dan atau rujukan semua kasus anemia pada kehamilan sesuai dengan ketentuan yang berlaku

\section{Standar 5. Pengelolaan Dini Hipertensi Pada kehamilan}

Bidan menemukan secara dini setiap kenaikan tekanan darah pada kehamilan mengenali tanda dan gejala preeklamsi lainnya, mengambil tindakan yang tepat dan merujuknya.

\section{Standar 6. Persiapan Persalinan}

Bidan memberikan saran yang tepat kepada ibu hamil, suami dan keluarganya pada trimester ketiga untuk memastikan bahwa persiapan persalinan bersih dan aman serta suasana yang menyenangkan akan direncanakan dengan baik, disamping persiapan transportasi dan biaya untuk merujuk bila tiba-tiba terjadi keadaan gawat darurat. Oleh karena itu, bidan sebaiknya melakukan kunjungan rumah.

2. Kebijakan program : Anjuran WHO

- Trimester I : 1 kali kunjungan

- Trimester II : 1 kali kunjungan

- Trimester III : 2 kali Kunjungan

Standar Minimal Asuhan Antenatal 7T

- Timbang berat badan

- Tinggi Fundus uteri

- Tekanan darah 
- Tetanus Toxoid

- Tablet Fe

- Tes PMS

- Temu Wicara

\section{J. TREN DAN ISU TERKINI DALAM ANC}

1. Keterlibatan klien dalam perawatan diri sendiri (self care)

Kesadaran dan tanggung jawab klien terhadap perawatan diri sendiri selama hamil semakin meningkat. Klien tidak lagi hanya menerima dan mematuhi anjuran petugas kesehatan secara pasif. Kecenderungan saat ini klien lebih aktif dalam mencari informasi berperan secara aktif dalam perawatan diri dan mengubah perilaku untuk mendapaatkan outcome kehamilan yang lebih baik. Kemampuan klien dalam merawat diri sendiri dipandang sangat menguntungkan baik bagi klien maupun system pelayanan kesehatan karena potensinya yang dapat menekan biaya perawatan. Dalam hal pilihan pelayanan yang diterima, ibu hamil dapat memilih tenaga professional yang berkualitas dan dapat dipercaya sesuai dengan tingkat pengetahuan dan kondisi sosioekonomi mereka.

2. ANC pada usia kehamilan lebih dini

Mengenai kunjungan ANC trimester pertama menunjukkan peningkatan yang signifikan. Hal ini sangat naik karena memungkinkan professional kesehatan mendeteksi dini dan segera menangani masalah-masalah yang timbul sejak awal kehamilan. Kesempatan untuk memberikan pendidikan kesehatan tentang perubahan perilaku yang diperlukan selama hamil juga lebih banyak.

3. Praktik yang berdasarkan bukti (evidence based practice) 
Parktik kebidanan sekarang lebih didasarkan pada bukti ilmiah hasil penelitian dan pengalaman praktik dari pada praktisi dari seluruh penjuru dunia. Rutinitas yang tidak terbukti manfaatnya kini tidak dianjurkan lagi

Isu terkini dalam praktik kebidanan yang sangat fenomenal adalah lotus birth yang membuat Robin Lim mendapat penghargaan yang membanggakan sejawat di seluruh dunia. Lotus birth atau tali pusat yang tidak dipotong adalah praktek meninggalkan tali pusat yang tidak di klem dan lahir secara utuh dari pada ikut menghalangi proses fisiologi normal dalam perubahan Wharton's jelly yang menghasilkan pengkleman internal alami dalam 10-20 menit pasca persalinan.

Organisasi Kesehatan Dunia (WHO) menekankan pentingnya penyatuan atau penggabungan pendekatan untuk asuhan ibu dan bayi, dan menyatakan dengan jelas bahwa "penundaan pengkleman atau tidak sama sekali diklem adalah cara fisiologis dalam perawatan tali pusat, dan pengkleman tali pusat secara dini merupakan intervensi yang masih memerlukan pembuktian lebih lanjut". Lotus Birth jarang dilakukan di rumah sakit tetapi umumnya dilakukan di klinik dan rumah bersalin, sehingga proses bondig attachment antara ibu dan bayi dapat dilakukan hal ini tentunya bermanfaat bagi ibu dan bayi yang baru lahir.

\section{K.EVIDENCE BASED DALAM PRAKTIK KEHAMILAN}

Praktik yang berdasarkan bukti penelitian adalah penggunaan secara sistematis, ilmiah dan eksplisit dari bukti terbaik mutakhir dalam membuat keputusan tentang asuhan bagi pasien secara individual. 
Hasil penelitian/evidence based yang menjadi dasar standar pelayanan dalam praktik kehamilan adalah :

1. Kunjungan ANC

Dilakukan minimal 4 kali selama kehamilan

\begin{tabular}{|c|c|c|}
\hline Kunjungan & Waktu & Alasan \\
\hline TM I & $\begin{array}{l}\text { Sebelum } \\
14 \\
\text { minggu }\end{array}$ & $\begin{array}{l}>\text { Mendeteksi masalah yang dapat ditangani } \\
\text { sebelum membahayakan jiwa } \\
>\text { Mencegah masalah misalnya tetanus } \\
\text { neonatal, anemia, kebiasaan tradisional } \\
\text { yang berbahaya } \\
>\text { Membangun hubungan saling percaya } \\
>\text { Memulai persiapan kelahiran dan } \\
\text { kesiapan menghadapi komplikasi } \\
>\text { Mendorong perilaku sehat (nutrisi, } \\
\text { kebersihan, olahraga, istrahat, seks). }\end{array}$ \\
\hline TM II & $\begin{array}{l}14-28 \\
\text { minggu }\end{array}$ & $\begin{array}{l}\text { Sama dengan trimester I ditambah } \\
\text { kewaspadaan khusus terhadap hipertensi } \\
\text { kehamilan (deteksi gejala preeklamsia, } \\
\text { pantau TD, evaluasi edema dan } \\
\text { proteinuria). }\end{array}$ \\
\hline \multirow[t]{2}{*}{ TM III } & $\begin{array}{l}28-36 \\
\text { Minggu }\end{array}$ & $\begin{array}{l}\text { Sama dengan Trimester I, ditambah degan } \\
\text { deteksi kehamilan ganda }\end{array}$ \\
\hline & $\begin{array}{l}\text { Setelah } \\
36 \\
\text { minggu }\end{array}$ & $\begin{array}{l}\text { Sama dengan TM II ditambah dengan } \\
\text { deteksi kelainan letak atau kondisi yang } \\
\text { memerlukan persalinan di RS }\end{array}$ \\
\hline
\end{tabular}




\section{Pemberian suplemen mikronutrien}

Tablet yang mengandung FeSO4 $320 \mathrm{mg}$ (= zat besi $60 \mathrm{mg}$ ) dan asam folat $500 \mu \mathrm{g}$ sebanyak 1 tablet /hari segera setelah rasa mual hilang. Pemberian selama 90 hari (3 bulan). Ibu harus dinasehati agar tidak meminunya bersama kopi / the agar tidak mengganggu penyerapannya.

3. Imunisasi TT $0,5 \mathrm{cc}$

\begin{tabular}{|l|l|l|l|}
\hline Imunisasi & Interval & $\begin{array}{l}\text { Lama } \\
\text { Perlindungan }\end{array}$ & $\begin{array}{l}\text { Perlindungan } \\
\%\end{array}$ \\
\hline TT1 & $\begin{array}{l}\text { Pada kunjungan ANC } \\
\text { Pertama }\end{array}$ & - \\
\hline TT2 & 4 minggu setelah TT1 & 3 tahun & $80 \%$ \\
\hline TT3 & 6 bulan setelah TT2 & 5 tahun & $95 \%$ \\
\hline TT4 & 1 tahun setelah TT3 & 10 Tahun & $99 \%$ \\
\hline TT5 & 1 tahun seuelah TT4 & $\begin{array}{l}25 \text { Tahun/seumur } \\
\text { hidup }\end{array}$ & $99 \%$ \\
\hline
\end{tabular}

4. Perkiraan HB pada Kehamilan

a. Dalam kehamilan normal akan terjadi penurunan kadar HB. Kadar terendah terjadi sekitar kehamilan 30 minggu. Oleh karena itu pemeriksaan $\mathrm{Hb}$ harus dilakukan pada kehamilan dini untuk melihat data awal lalu di ulang pada kehamilan 30 minggu.

b. Bila $\mathrm{Hb}$ rendah $(<9 \mathrm{gr} \%)$ harus dilakukan pemeriksaan dan pengobatan yang sesuai.

c. Anemia ringan penyebabnya adalah defisiensi zat besi, dapat diobati secara efekif dengan suplementasi besi. 
d. Semua ibu hamil terutama yang mendapat suplementasi besi harus mendapat nasihat gizi khusunya menghindari tembakau,kopi dan teh

5. Perkiraan tinggi fundus uteri (TFU)

a. Pengukuran menggunakan pita pengukur memberikan hasil yang konsisten antara individu meskipun masih terjadi sedikit variasi

b. Pengukuran TFU pada kehamilan lanjut/saat persalinan dalam posisi telentang terbukti memberikan hasil yang lebih tinggi dari yang sebenarnya sehingga hal tersebut menyebabkan perkiraan umur kehamilan yang salah.

c. Program nasional menganjurkan posisi stengah duduk pada saat pengukuran TFU. Di ukur dengan menggunakan pita ukur standar untuk memberikan interprestasi pertumbuhan janin yang benar

d. Pengukuran TFU bila dilakukan oleh petugas yang sama setiap kunjungan terbukti memiliki nilai prediktif yang baik terutama mengidentifikasi adanya gangguan pertumbuhan intrauteri.

Evidence Base dalam Praktik Kebidanan Terkini menurut Reproduksi :

$\mathrm{EBM}$ - ANC

\begin{tabular}{|l|l|}
\hline Kebiasaan & Keterangan \\
\hline $\begin{array}{l}\text { Diet rendah garam untuk } \\
\text { mengurangi hipertensi }\end{array}$ & $\begin{array}{l}\text { Hipertensi bukan karena retensi } \\
\text { garam }\end{array}$ \\
\hline $\begin{array}{l}\text { Membatasi hubungan seksual } \\
\text { untuk mencegah abortus dan } \\
\text { kelahiran premature }\end{array}$ & $\begin{array}{l}\text { Dianjurkan untuk memakai } \\
\text { kondom ada sel semen yang } \\
\text { mengandung prostaglandin tidak } \\
\text { kontak langsung dengan organ } \\
\text { reproduksi yang dapat memicu } \\
\text { kontraksi uterus. }\end{array}$ \\
\hline
\end{tabular}




\begin{tabular}{|l|l|}
\hline $\begin{array}{l}\text { Pemberian kalsium untuk } \\
\text { mencegah kram pada kaki }\end{array}$ & $\begin{array}{l}\text { Kram pada kaki bukan semata- } \\
\text { mata oleh } \\
\text { kekurangan kalsium }\end{array}$ \\
\hline $\begin{array}{l}\text { Aktifitas dan mobilisasi/latihan } \\
\text { (senam hamil dan lain-lain) saat } \\
\text { masa kehamilan menurunkan } \\
\text { kejadian PEB, gestasional } \\
\text { diabetes dan BBR serta } \\
\text { persalinan SC }\end{array}$ & $\begin{array}{l}\text { Berkaitan dengan peredaraan } \\
\text { darah dan kontraksi otot. }\end{array}$ \\
\hline $\begin{array}{l}\text { Diet untuk mencegah bayi besar } \\
\text { Bayi besar disebabkan oleh } \\
\text { gangguan metabolisme pada ibu } \\
\text { seperti diabetes mellitus. }\end{array}$ \\
\hline
\end{tabular}

EBM INC dan PNC

\begin{tabular}{|l|l|}
\hline \multicolumn{1}{|c|}{ Kebiasaan } & \multicolumn{1}{|c|}{ Keterangan } \\
\hline Tampon Vagina & $\begin{array}{l}\text { Tampon vagina menyerap darah } \\
\text { tetapi tidak menghentikan } \\
\text { perdarahan, bahkan perdarahan } \\
\text { tetap terjadi dan dapat } \\
\text { menyebabkan infeksi }\end{array}$ \\
\hline Gurita atau Sejenisnya & $\begin{array}{l}\text { Selama 2 jam pertama atau } \\
\text { selanjutnya penggunaan gurita } \\
\text { akan menyebabkan kesulitan } \\
\text { pemantauan involusio Rahim }\end{array}$ \\
\hline Memisahkan ibu dan bayi & $\begin{array}{l}\text { Bayi benar-benar siaga selama 2 } \\
\text { jam pertama setelah kelahiran. } \\
\text { Ini merupak waktu yang tepat } \\
\text { untuk melakukan kontak kulit ke } \\
\text { kulit untuk mempererat bonding } \\
\text { attachment serta keberhasilan } \\
\text { pemberian ASI. }\end{array}$ \\
\hline Menduduki sesuatu yang panas & $\begin{array}{l}\text { Duduk diatas bara yang panas } \\
\text { dapat menyebabkan vasodilatasi, }\end{array}$ \\
\hline
\end{tabular}


menurunkan tekanan darah ibu dan menambah perdarahan serta menyebabkan dehidrasi. 


\section{BAB II}

\section{PROSES ADAPTASI FISIOLOGI DAN PSIKOLOGIS DALAM MASA KEHAMILAN}

\section{A. PENDAHULUAN}

1. Deskripsi singkat

Perkuliahan ini membahas tentang perubahan anatomi dan fisiologi pada ibu hamil yang meliputi perubahan pada sistem reproduksi, sistem cardiovaskuler, sistem integumen, sistem metabolisme, sistem pernafasan, darah dan pembekuan darah dan perubahan berat badan.

2. Tujuan Istruksional Khusus (TUK)

Setelah mengikuti kuliah ini mahasiswa mampu menjelaskan proses adaptasi fisologis dan psikologis dalam masa kehamilan.

\section{B. ANATOMI FISIOLOGI ORGAN REPRODUKSI WANITA}

\section{Genitalia Eksterna dan Interna}

Organ reproduksi manusia terbentuk sejak embrio yaitu pada usia kehamilan 6 minggu, maka sejak dini jenis kelamin sudah dapat ditentukan. Anatomi dan fisiologi alat reproduksi perlu diketahui bagi seorang bidan. Organ-organ yang membentuk alat reproduksi perempuan dibagi menjadi 2 bagian,yaitu genitalia eksterna dan genitalia interna

\section{a.Mons Pubis}

Mons pubis atau mons veneris merupakan jaringan lemak subkutan berbentuk bulat yang lunak dan padat serta merupakan jaringan ikat di atas simfisis pubis. Mons pubis banyak mengandung kelenjar sebasea (minyak) dan ditumbuhi rambut berwarna hitam, kasar, dan ikal pada masa pubertas, yaitu sekitar satu sampai dua tahun 
sebelum awitan haid. Rata-rata menarche (awitan haid) terjadi pada usia13 tahun. Mons berperan dalam sensualitas dan melindungi simfisis pubis selama koitus (hubungan seksual). Semakin bertambahnya usia, jumlah jaringan lemak di tubuh wanita berkurang dan rambut pubis menipis

\section{b.Labia Mayora (bibir Besar)}

Labia mayor adalah dua lipatan kulit panjang melengkung yang menutupi lemak dan jaringan ikat yang menyatu dengan mons pubis. Keduanya memanjang dari mons pubis ke arah bawah mengelilingi labia minor, berakhir di perineum pada garis tengah. Labia mayor memiliki panjang 7-8 cm, lebar 2-3 cm, dan tebal $1-1,5 \mathrm{~cm}$ dan agak meruncing pada ujung bawah. Labia mayor melindungi labia minor, meatus urinarius, dan introitus vagina (lubang vagina). Pada wanita yang belum pernah melahirkan pervagina, kedua labia mayor terletak berdekatan di garis tengah menutupi struktur-struktur di bawahnya. Setelah melahirkan anak dan mengalami cedera pada vagina atau perineum, labia sedikit terpisah bahkan introitus vagina terbuka. Penurunan produksi hormone menyebabkan atrofi labia mayor. Permukaan medial (arah dalam) labia mayor licin, tebal dan tidak ditumbuhi rambut. Bagian ini mengandung suplai kelenjar sebasea dan banyak kelenjar keringat serta banyak mengandung pembuluh darah. Labia mayor sensitive terhadap nyeri, sentuhan, dan suhu tinggi. Hal ini diakibatkan adanya jaringan saraf yang menyebar luas, yang berfungsi sebagai rangsangan seksual. 


\section{c. Labia Minora (bibir kecil)}

Labia minor terletak di antara dua labia mayor dan merupakan lipatan kulit yang panjang, sempit, dan tidak berambut, yang memanjang ke arah bawah dari bawah klitoris dan menyatu dengan fourchette. Sementara bagian lateral dan anterior labia biasanya mengandung pigmen, permukaan medial labiaminor sama dengan mukosa vagina merah muda dan basah. Pembuluh darah yang banyak membuat labia berwarna merah kemerahan dan memungkinkan labia minor membengkak, bila ada stimulus emosional dan stimulus fisik. Kelenjar di labia minor juga melumasi vulva. Suplai saraf yang banyak membuat labia minor menjadi sensitif. Ruangan antara kedua labia minor disebut vestibulum.

\section{d.Klitoris}

Klitoris adalah organ pendek berbentuk silinder dan erektil yang terletak di bawah arkus pubis. Dalam keadaan tidak terangsang bagian yang terlihat sekitar $6 \times 6 \mathrm{~mm}$ atau kurang. Ujung badan klitoris dinamakan glans dan lebih sensitive dari pada badannya. Saat wanita secara seksual terangsang, glands dan badan klitoris membesar. Kelenjar sebasea klitoris mensekresi smegma, suatu substansi lemak seperti keju yang memiliki aroma khas dan berfungsi sebagai feramen (senyawa organic yang memfasilitasi komunikasi olfaktorius) dan anggota lain pada spesies yang sama untuk membangkitkan respon tertentu, yang dalam hal ini adalah stimulasi erotis pada pria). Klitoris bearasal dari kata dalam bahasa Yunani, yang berarti "kunci” karena klitoris dianggap sebagai kunci seksualitas wanita. Jumlah pembuluh darah dan persarafan yang 
banyak membuat klitoris sangat sensitive terhadap suhu, sentuhan, dan sensasi tekanan. Fungsi utama klitoris yaitu untuk menstimulasi dan meningkatkan ketegangan seksual

\section{e. Vestibulum}

Vestibulum adalah suatu daerah yang berbentuk lonjong, terletak antara labia minora, klitoris, dan fourchette. Vestibulum terdiri dari dua muara uretra, kelenjar parauretra (vetibulum minus atau Skene),vagina, dan kelenjar paravagina (vestibulum mayus, vulvovagina, atau Bartholin). Permukaan vestibulum yang tipis dan agak berlendir mudah teritasi oleh bahan kimia (deodorant semprot, garam-garaman,busa sabun), panas, rabas, friksi (celana jins yang ketat). Meatus uretra juga merupakan bagian dari reproduksi karena letaknya dekat dan menyatu dengan vulva. Meatus mempunyai muara dengan bentuk bervariasi dan berwarna merah muda atau kemerahan, dan sering disertai tepi yang agak berkerut. Meatus menandai bagian terminal atau distaluretra. Biasanya terletak sekitar 2,5 cm di bawah klitoris. Kelenjar vestibulum minora adalah struktur tubular pendek yang terletak pada arah posterolateral didalam meatus uretra. Kelenjar ini memproduksi sejumlah kecil lender yang berfungsi sebagai pelumas. Kelenjar vestibulum mayor adalah gabungan dua kelenjar di dasar labia mayor masing-masing satu pada setiap sisi orifisium vagina. Beberapa duktus dengan panjang 1,5 cm, menjadi saluran pengeluaran drain setiap kelenjar. Setiap duktus membuka ke lekukan antara hymen dan labia minor. Kelenjar mensekresi sejumlah kecil lender yang jernih dan lengket, terutama setelah koitus. Keasaman lender yang rendah ( $\mathrm{pH}$ tinggi) 


\section{f. Hymen}

Hymen merupakan lipatan yang tertutup mukosa sebaigan, bersifat elastic, tetapi kuat, dan terletak disekitar introitus vagina. Pada wanita yang perawan, hymen dapat menjadi penghalang pada pemeriksaan dalam, pada insersi tampon menstruasi atau koitus. Hymen ini bersifat elastic sehingga memungkinkan distensi dan dapat mudah robek. Terkadang hymen menutupi seluruh orifisum yangmenyebabkan hymen tertutup secara abnormal dan menghalangi pasase aliran cairan menstruasi,pemasangan alat (spekulum), atau koitus. Setelah pemasangan alat, pemakaian tampon, atau melahirkan pervaginam, dapat terlihat sisa robekan hymen (karunkulae hymen atau karunkulamirtiformis).

\section{g.Perineum}

Terletak diantara vulva dan anus, panjang sekitar $4 \mathrm{~cm}$. perineum mempunyai susunan otot-otot dan susunan saraf serta pembuluh darah yang kompleks. Pada saat persalinan,apabila terjadi rupture total kan sangat membahayakan sebab biasa mengenai sfingter ani sehingga mengakibatkan terjadinya inkotinensia alvi (buang air besar tidak terasa).

\section{Genitalia interna}

\section{a. Vagina}

Merupakan liang senggama, saluran yang menghubungkan vulva dan Rahim terletak diantara kandung kemih dan rectum. Dinding depan vagina memiliki panjang 7-9 $\mathrm{cm}$ dan dinding belakang 9-11 cm. dinding vagina berlipat-lipat berjalan sirkular dan disebut rugae. dinding vagina terdiri dari 3 lapisan yaitu 
lapisan mukosa, lapisan otot dan lapisan jaringan ikat. Ke dalam puncak vagina menonjol ujung servik dan bagian yang menonjol ke dalam vagina disebut porsio. PH vagina yang normal sekitar 3,8-4,5 ini memberi proteksi dari invasi (penyebaran) kuman. Fungsi Vagina

1. Sebagai saluran keluar yang dapat mengalirkan darah haid dan secret dari uterus

2. Sebagai tempat koitus

3. Sebagai jalan lahir dari janin.

\section{b. Uterus (Rahim)}

Merupakan suatu struktur otot yang cukup kuat dimana bagian luarnya ditutupi oleh peritoneum sedangkan rongga dalamnya dilapisi oleh mukosa Rahim. Dalam keadaan tidak hamil Rahim terletak dalam rongga panggul kecil diantara kandung kemih dan rectum. Bentuknya seperti bola lampu yang gepeng atau buah alpukat yang terdiri atas 3 bagian yaitu sebagai berikut :

1. Badan Rahim (korpus uteri) berbentuk segitiga

2. Leher Rahim (serviks uteri) berbentuk silinder

3. Rongga Rahim ( kavum uteri)

Bagian rahim antara kedua pangkal tuba disebut fundus uteri, merupakan bagian proksimal rahim. Besarnya rahim berbeda-beda tergantung pada usia dan pernah melahirkan anak atau belum. Ukurannya kira-kira sebesar telur ayam kampung. Sebelah atas rongga Rahim berhubungan dengan tuba falopii dan sebelah bawah dengan saluran leher Rahim (kanalis servikalis). Hubungan antara kavum uteri dan kanalis servikalis ke dalam vagina uterus disebut 
ostium eksternum. Isthmus adalah bagian uterus antara korpus dan serviks uteri diliputi oleh peritoneum. Daerah ini pada awal kehamilan akan menjadi lunak (tanda Hegar). Pada persalinan daerah isthmus merupakan batas antara segmen atas Rahim dan segmen bawah Rahim yang akan terjadi peregangan. Bila uterus diregang akan mengakibatkan rupture yang ditandai dengan adanya lingkaran bandle. Pembuluh darah yang terdapat di uterus yaitu arteri uterine dan arteri ovarika.

Dinding Rahim terdiri dari 3 lapisan, yaitu sebagai berikut :

1. Lapisan serosa (perimetrium terletak paling luar

2. Lapisan otot (myometrium) terletak ditengah

3. Lapisan mukosa (endometrium) lapisan paling dalam.

Dalam siklus menstruasi yang selalu berubah adalah lapisan daerah endometrium Sikap dan letak uterus dalam rongga panggul terfiksasi dengan baik karena disokong dan dipertahankan oleh :

1. Tonus Rahim

2. Tekanan intra abdominal

3. Otot-otot dasar panggul

4. Ligamentum-ligamentum :

a. Ligamentum latum terletak di kanan dan kiri uterus sampai ke dinding dan dasar panggul sehingga seolah-olah uterus menggantung pada tuba.

b. Ligamentum rotundum (teres uteri) terdapat di bagian atas uterius berfungsi untuk menahan uterus dalam keadaan antefleksi. 
c. Ligamentum infundibulo pelvikum terletak di kanan kiri dari infundibulum dan ovarium berfungsi untuk menggantung uterus pada dinding panggul

d. Ligamentum kardinale terletak dikanan kiri dari serviks setinggi ostium internum

e. Ligamentum sakro uternum terletak di kanan kiri dari serviks sebelah belakang

f. Ligamentum vesiko uternum terletak di daerah uterus ke kandung kencing

Beberapa letak uterus yaitu antara lain :

1. Ante fleksi (menekan ke depan )letak yang fisiologis

2. Retro fleksi menghadap kebelakang

3. Ante versio dimana uterus terdorong ke depan

4. Retro versio dimana uterus terdorong kebelakang

5. Torsio yaitu uterus yang memutar

Fungsi Utama Uterus yaitu sebagai berikut :

1. Setiap bulan berfungsi dalam pengeluaran darah haid dengan adanya perubahan dan pelepasan dari endometrium

2. Tempat janin tumbuh dan berkembang

3. Tempat melekatnya plasenta

4. Pada kehamilan, persalinan dan nifas mengadakan kontraski untuk lancarnya persalinan dan kembalinya uterus pada saat involusio.

\section{Letak uterus}

1. Ante dan Retrofleksio uteri 
Sumbu serviks dan sumbu korpus uteri membentuk sudut, jika membuka kedepan disebut antefleksio jika membuka kebelakang disebut retrofleksio.

\section{Positio}

Uterus tidak terletak pada sumbu panggul bisa lebih kekiri (sinistro), kekanan (dextro), kedepan (antero) dan bisa lebih kebelakang (dorso position)..

\section{Torsio}

Letak Uterus biasanya agak berputar

\section{Ante dan retroversion uteri}

Sumbu vagina dan uterus membentuk sudut, jika membuka kedepan disebut anteversio jika kebelakang disebut retroversion.

\section{c. Tuba Fallopii ( Saluran Telur )}

Tuba ini terdapat pada tepi atas ligamentum latum, berjalan kearah lateral mulai dari korpus uteri kanan kiri. Pajangnya \pm 12 $\mathrm{cm}$ dengan diameter $3-8 \mathrm{~cm}$.

Tuba fallopi dibagi menjadi 4 bagian yaitu :

1.Pars interstisialis (intarmuralis)

Bagian tuba yang berjalan dalam dinding uterus mulai dari ostium tuba

2.Pars ismika

Bagian tuba setelah keluar dari dinding uterus dan merupakan bagian dari tuba yang lurus dan sempit

3. Pars ampullaris 
Bagian tuba antara pars simika dan infundibulum merupakan bagian tuba yang paling lebar dan berbentuk S.pada bagian inilah biasanya terjadi konsepsi

\section{Infundibulum}

Merupakan ujung dari tuba dengan umbai-umbai yang disebut fimbriae lubangnya disebut ostum abdominale tuba.

Fungsi tuba yaitu untuk menangkap membawa ovum yang dilepas ovarium kearah kavum uteri serta tempat terjadinya konsepsi

\section{d. Ovarium (indung telur)}

Ovarium ada dua terletak dikiri dan kanan uterus dihubungkan oleh ligamentum ovarii propium dengan dinding panggul oleh ligamentum infundibulum pelvikum. Ukuran ovarium sekitar 2,5-5 cm x 1,5-3 cm x 0,9-1,5 cm dengan berat sekitar 4-8 gram.

Fungsi ovarium :

1. Mengeluarkan hormone progestron dan estrogen

2. Mengeluarkan telur setiap bulan

\section{PANGGUL}

Panggul yang dikenal penting dalam ilmu kebidanan adalah panggul kecil (pelvis minor) yang merupakan wadah alat kandungan dan menentukan bentuk jalan lahir, sedangkan panggul besar (pelvis mayor) berfungsi untuk menyangga isi perut dan bias menggambarkan keadaan panggul kecil.

Panggul wanita terdiri atas bagian-bagian berikut

a. Bagian keras yang dibentuk oleh 4 buah tulang

1) 2 tulang pangkal paha (os Koksae) 
2) 1 tulang kelangkang (os Sakrum)

3) 1 tulang tungging (koksigis)

b. Bagian lunak daifragma pelvis dibentuk oleh bagian-bagian berikut

1) Pars muskularisl levator ani

2) Pars membranesea

3) Region perineum

\section{Bagian Panggul Yang Keras}

1. Tulang pangkal paha

Terdiri dari 3 buah tulang yang berhubungan satu sama lain pada acetabulum yaitu :

a. Tulang usus (os ilium)

Merupakan tulang terbesar dari panggul dan membentuk dan membentuk bagian atas dan belakang panggul. Bagian pinggir atas disebut krista iliaka, ujung depan dan belakang dari krista iliaka yang menonjol disebut spina iliaka anterior superior dan spina iliaka posterior superior.

b. Tulang duduk (os iskium)

Disebelah bawah tulang usus pada bagian pinggir belakang berdiri spina iskiadika. Ukuran atau jarak spina iskiadika kanan dan kiri merupakan ukuran bidang tengah panggul. Pinggir bawah tulang duduk sangat tebal, bagian ini mendukung berat badan kalau kita duduk (tuber isciadikum) yang merupakan ukuran melintang dari pintu bawah panggul

c. Tulang kemaluan

Tulang ini membatasi sebuah lubang yang terdapat dalam panggul (foramen obturatorium). Tulang kemaluan yang 
berhubungan dengan tulang usus disebut ramus superior osis pubis, sedangkan yang berhubungan dengan tulang duduk disebut ramus inferior osis pubis. Ramus inferior kanan kiri membentuk arcus pubis (normalnya membentuk sudut $90^{\circ}-$ $100^{\circ}$.

2. Tulang kelangkang (os sacrum)

Tulang ini berbentuk segitiga yang melebar diatas dan meruncing ke bawah. Tulang ini terletak disebelah belakang antara kedua tulang pangkal paha dan terdiri dari 5 ruas tulang yang senyawa.

a. Terdiri atas 5 ruas yang berhubungan erat

b. Permukaan depan licin dengan lengkungan dari atas ke bawah dan dari kanan maupun kiri.

c. Pada bagian kanan dan kiri, garis tengah terdapat lubang yang akan dilalui saraf. Lubang tersebut dinamakan foramina sacralia anterior.

d. Tulang kelangkang berhubungan dengan tulang pinggang ruas ke-5

e. Tulang kelangkang yang paling atas mempunyai tonjolan besar kedepan disebut promontorium

f. Kesamping tulang kelangkang berhubungan dengan tulang pangkal paha melalui artikulasio sacro-iliaca.

g. Kebawah tulang kelangkang berhubungan dengan tulang tungging 
3. Tulang Tungging

Tulang ini berbentuk segitiga dan terdiri atas 3-5 ruas yang bersatu. Pada waktu persalinan ujung tulang ini dapat ditolak sedikit kebelakang sehingga ukuran panggul bertambah besar.

\section{Bagian Panggul Yang Lunak}

Bagian yang membentuk dasar panggul disebut diafragma pelvis yang dibentuk oleh bagian-bagian berkut ini :

1. Pars muskularis levator ani

a. Muskulus pubococygeus dari ossis pubis ke septum anocccygeum

b. Muskulus iliococcygeus dari arkus tendineus muskulus levator ani ke os cosigeus dan septum annocosygeum

c. Muskulus ischiococcygeum dari spina ischiadika ke pinggir os sacrum dan os cocsigis

2. Pars membranasea

a. Hiatus urogenitalis terletak diantara kedua muskulus pubococcygeus dan berbentuk segitiga

b. Diafragma urogenitalis menutupi hiatus urogenitalis dan bagian depannya ditembus oleh uretra dan vagina.

3. Region perineum

Merupakan bagian permukaan pintu bawah panggul terbagi menjadi bagian-bagian dibawah ini:

a. Bagian anal (sebelah belakang) terdapat muskulus spingter ani eksternum yang mengelilingi anus dan liang sanggama bagian bawah. 
b. Region urogenitalis terdapat muskulus ischiokavernosus dan muskulus transversus perinei supervisialis

Fungsi umum panggul wanita adalah seagai berikut :

1. Bagian keras panggul yaitu panggul besar untuk menyangga isi abdomen sedangkan panggul kecil untuk membentuk jalan lahir dan tempat alat genitalia

2. Bagian lunak panggul wanita yaitu membentuk lapisan dalam jalan lahir, menyangga alat genitalia agar tetap dalam posisi yang normal saat hamil mupun saat kala nifas serta saat persalinan berperan dalam proses kelahiran dan kala plasenta.

\section{Ukuran-Ukuran Panggul}

1. Panggul Kecil (Pelvis Minor)

Panggul kecil dalam ilmu kebidanan mempunyai arti penting karena merupakan tempat alat reproduksi wanita dan membentuk jalan lahir berbentuk corong dengan luas bidang yang berbeda-beda sehingga dapat menentukkan posisi dan letak terendah janin yang melalui jalan lahir itu.

Ukuran-ukuran panggul

1) Terdiri atas 4 bidang

a) Pintu atas panggul

Pintu atas panggul (PAP) merupakan bulatan oval dengan panjang ke samping dan dibatasi oleh bagian-bagian berikut :

- Promontorium

- Sayap os sacrum 
- Linea terminalis kanan dan kiri

- Pinggir atas simfisis pubis

Pada pintu atas panggul (PAP) ditentukan tiga ukuran penting yaitu ukuran muka belakang (konjugata vera), ukuran melintang (diameter transversa) dan ukuran serong (diameter oblique).

- Ukuran muka belakang (konjugata Vera).

Panjang sekitar $11 \mathrm{~cm}$ tidak dapat diukur secara langsung tetapi ukuranya dapat diperhitungkan melalui pengukuran konjugata diagonalis. Konjugata diagonalis terletak antara promontorium dan tepi bawah sympisis pubis. Konjugata vera $(\mathrm{CV})=\mathrm{CD}-1,5 \mathrm{~cm}$. Konjugata obstetrika yaitu ukuran antara promontorium dengan tonjoan simpisis pubis.

- Ukuran melintang (diameter transversa).

Jarak antara kedua linea terminalis diambil tegak lurus pada konjugata vera, ukurannya $12,5-13,5 \mathrm{~cm}$.

- Ukuran serong (diameter oblique).

Jarak antara artiulasio sacro-iliaca menuju tuberkulum pubikum yang bertentangan. Kedua ukuran ini tidak dapat di ukur pada wanita yang masih hidup. Ukuran normalnya $\pm 13 \mathrm{~cm}$

b)Bidang terluas panggul

Merupakan bidang dengan ukuran-ukuran terbesar. Bidang ini terbentuk antara pertengahan simfisis, pertengahan asetabulum serta pertemuan antara ruas kedua dan ketiga 
tulang kelangkang. Ukuran muka belakang $11,75 \mathrm{~cm}$ sedangkan ukuran melintang $12,5 \mathrm{~cm}$.

c) Bidang tersempit panggul

Bidang ini mempunyai ukuran-ukuran terkecil jalan lahir. Membentang setinggi tepi bawah sympisis menuju kedua spina isciadika dan memotong tulang kelangkang setinggi 1-2 cm diatas ujungnya. Ukuran muka belakang11,5 cm dan ukuran melintangnya $10 \mathrm{~cm}$. bidang ini merupakan titik putar dari PAP menjadi PBP.

d)Pintu bawah panggul

Pintu bawah panggul (PBP) terdiri atas dua segitiga dengan dasar yang sama

- Segitiga depan : dasarnya tuber osis ischiadika dengan dibatasi arcus pubis.

- Segitiga belakang : dasarnya tuber os isciadika dengan dibatasi oleh ligamentum sakrotuberusum kanan dan kiri. Ukuran muka belakang $11 \mathrm{~cm}$ (tepi bawah sympisis menuju ujung tulang kelangkang), ukuran melintang 10,5 $\mathrm{cm}$ jarak antara kedua tuber os isciadika kanan dan kiri serta diameter sagitalis posterior 7,5 cm (ujung tulang kelangkang ke pertengahan ukuran melintang ).

\begin{tabular}{|l|l|l|}
\hline Bidang pelvis & Diameter & $\begin{array}{l}\text { Ukuran } \\
(\mathbf{c m})\end{array}$ \\
\hline Pintu atas panggul & Konjugata vera & 11,5 \\
& Konjugata obstetric & 11,0 \\
& Transversal & 13,5 \\
\hline
\end{tabular}




\begin{tabular}{|l|l|l|}
\hline & Oblik & 12,5 \\
& Posterior sagital & 4,5 \\
\hline Diameter terbesar & Anteroposterior & 12,75 \\
& Transversal & 12,5 \\
\hline Pintu tengah panggul & Anteroposterior & 12,0 \\
& Interspinarum & 10,5 \\
& Posterior sagital & $4,5-5,0$ \\
\hline Pintu bawah panggul & AP anatomic & 9,5 \\
& Ap obstetric & 11,5 \\
& Intertuberosum & 11 \\
& Posterior sagital & 7,5 \\
\hline
\end{tabular}

2) Jalan lahir merupakan corong yang melengkung ke depan dengan sifat berikut

a)Jalan lahir depan panjangnya $4.5 \mathrm{~cm}$

b)Jalan lahir belakang panjangnya $12,5 \mathrm{~cm}$

c)Pintu atas panggul menjadi pintu bawah panggul seolah berputar $90^{\circ}$

d)Bidang putar pintu atas panggul menjadi pintu bawah panggul terjadi pada bidang tersempit

e)Pintu bawah panggul bukanlah satu bidang tetapi dua segitiga dengan dasar pada

- Segitiga belakang pangkal (dasar) pada tuber osisi sichi dan ujung belakangnya os sacrum

- Segitiga depannya dengan ujung (puncak) pada simfisis pubis. 


\section{Ukuran Panggul}

1. Distansia Spinarum

Jarak antara spina iliaka anterior superior kanan kiri ukuran normal $23-26 \mathrm{~cm}$.

2. Distansia Kristarum

Jarak yang terjauh antar krista iliaka dan kiri 26-29 cm

3. Konjugata eksterana (boudelough)

Jarak antara pinggir atas sympisis dan ujung prosesus spinosum ruas tulang lumbal $\mathrm{ke} \mathrm{V} \pm 18-20 \mathrm{~cm}$.

4. Ukuran lingkar panggul

Dari pinggir atas sympisis ke pertengahan antara spina iliaka anterior superior dan trokanter mayor sepihak, kemudia kembali melalui tempat yang sama dipihak yang lain ukurannya 80-90 cm.

\section{Sumbu Panggul}

Adalah garis yang menghubungkan pusat-pusat dari beberapa bidang di dalam panggul berupa garis yang lurus di bagian atas sampai titik sedikit diatas spina isciadika dan kemudian melengkung ke depan di daerah Pintu Bawah Panggul (PBP).

\section{Bidang HODGE}

Adalah bidang khayal untuk menentukkan seberapa jauh bagian depan anak turun ke dalam rongga panggul

HODGE I adalah bidang yang dibentuk pada lingkaran Pintu Atas Panggul (PAP) dengan bagian atas sympisis dan promontorium 
HODGE II adalah bidang ini sejajar dengan Hodge I terletak setinggi bagian pinggir bawah sympisis

HODGE III adalah bidang ini sejajar dengan Hodge I dan II terletak setinggi spina ischiadika

HODGE IV adalah bidang ini sejajar dengan Hodge I,II dan III terletak setinggi os koksigis.

\section{Bentuk panggul}

Cldwell-Moloy mengemukakan empat bentuk dasar panggul yang didasarkan pada bentuk segmen posterior dan anterior dari PAP yaitu sebagai beriuku :
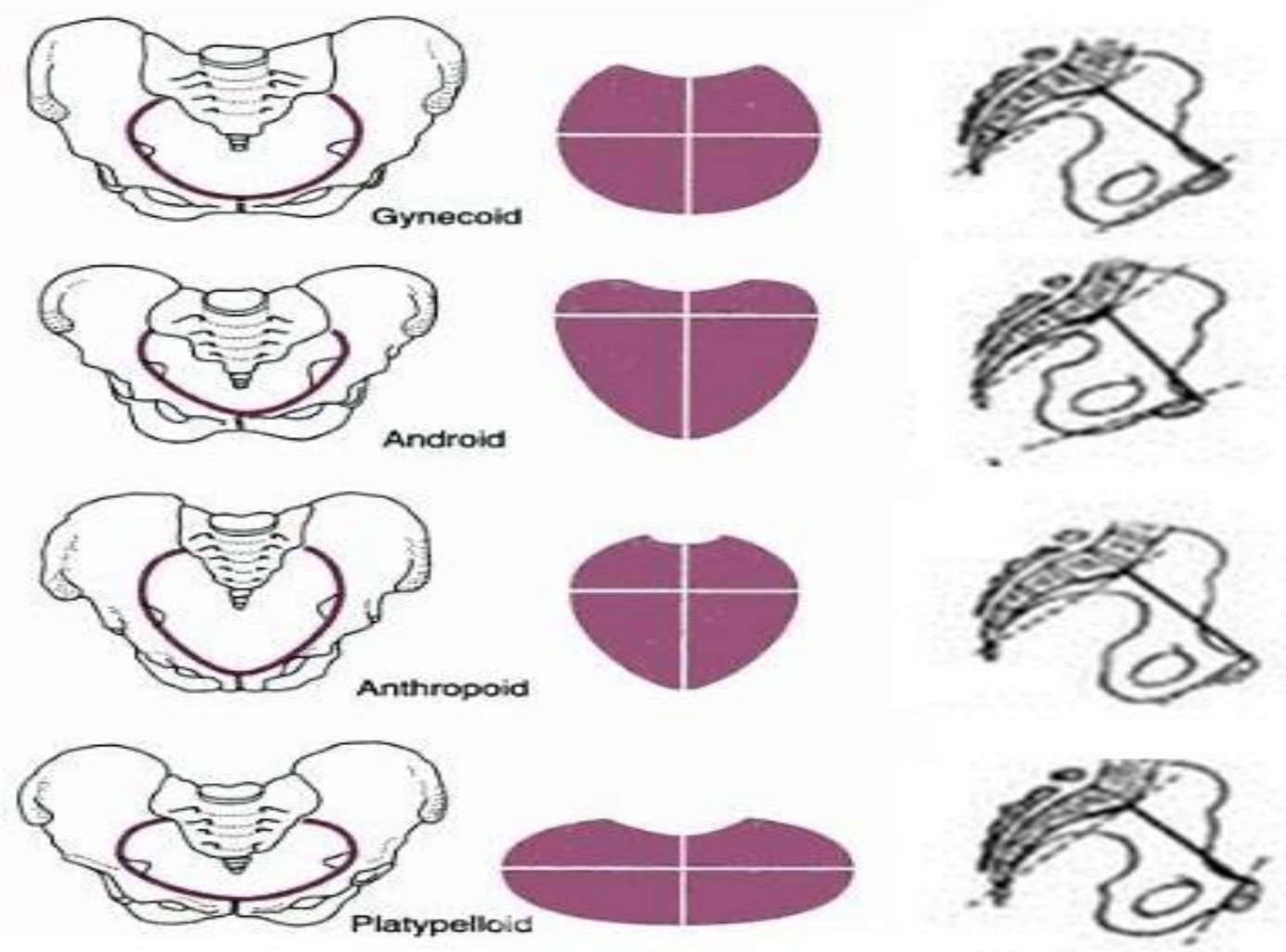

Gambar Bentuk Dasar Panggul 
Klasifikasi menurut Caldwell dan Molloy, bentuk panggul terbagi menjadi 4 yaitu:

1. Panggul gynecoid

Panggul yang paling ideal. Diameter anteroposterior sama dengan diameter transversa bulat. Jenis ini ditemukan pada $45 \%$ wanita.

2. Panggul android

Bentuk pintu atas panggul hampir segitiga. Umumnya pada panggul pria. Panjang diameter transversa dekat dengan sakrum. Pada wanita ditemukan $15 \%$.

3. Panggul anthropoid

Bentuk pintu atas panggulagak lonjong seperti telur. Panjang diameter anteroposterior lebih besar daripada diameter transversa. Jenis ini ditemukan $35 \%$ pada wanita.

4. Panggul platypeloid

Merupakan panggul picak. Diameter transversa lebih besar dari pada diameter anteroposterior, menyempit arah muka belakang. Jenis ini ditemukan pada 5\% wanita.

\section{C.SIKLUS HORMONAL}

Ciri kedewasaan manusia adalah adanya perubahan siklus pada alat kandungannya sebagai persiapan untuk kehamilan. Ini merupakan suatu proses yang kompleks dan harmonis meliputi serebrum, hipotalamus,hipofifis alat genitalia korteks, glandula tireoidea dan kelenjar-kelenjar lain yang kini masih membutuhkan penelitian lebih lanjut. Dewasa ini banyak diketahui tentang apa yang terjadi pada perubahan-perubahan siklik yang sama pada kera. 
Pada siklus haid endometrium dipersiapkan secara teratur untuk menerima ovum yang dibuahi setelah terjadi ovulasi, dibawah pengaruh secara ritmik hormon-hormon ovarium seperti estrogen dan progesterone. Hormon-hormon ini dapat ditemukan antara lain didalam air kencing dan pengeluarannya setiap 24 jam dapat diukur, estrogen sebagai estriol dan progesterone sebagai pregnandiol. Pemeriksaan urin setiap 24 jam ini dilakukan untuk mengetahui apakah fungsi ovarium normal.

Pada tiap siklus dikenal 3 masa utama yaitu :

1. Masa haid selama 2-8 hari. Pada waktu itu endometrium dilepas sedangkan pengeluaran hormone-hormon ovarium paling rendah.

2. Masa proliferasi sampai hari ke-14. Pada masa ini endometrium tumbuh kembali disebut juga endometrium mengadakan proliferasi. Antara hari ke 12-14 dapat terjadi pelepasan ovum dari ovarium yang disebut ovulasi.

3. Sesudahnya dinamakn masa sekresi. Pada masa ini korpus rubrum menjadi korpus luteum yang mengeluarkan progesterone. Dibawah pengaruh progesterone kelenjar endometrium yang tumbuh berkelokkelok mulai bersekresi dan mengeluarkan getah yang mengandung glikogen dan lemak. Pada akhir masa ini, yang berada di seputar pembuluh-pembuluh arterial. Keadaan ini memudahkan adanya nidasi.

\section{Ovulasi}

Ovulasi biasanya terjadi kira-kira 14 hari sebelum menstruasi yang akan datang dengan kata lain diantara dua haid yang berurutan, indung telur akan mengeluarkan ovum, setiap kali satu dari ovarium kanan dan lain kali dari ovarium kiri. Cara menentukkan adanya ovulasi : 
- Bipsi endometrium

- Suhu basal badan

- Sitology vaginal

- Getah serviks

- $\mathrm{pH}$ getah vagina

- Endoskopi

Setelah ovulasi sel-sel granulosa dari dinding folikel mengalami perubahan dan mengandung zat warna yang kuning disebut lutein sehingga folikel yang berubah menjadi butir telur yang kuning disebut korpus luteum yang mengeluarkan hormon estrogen dan progesterone. Bila terjadi konsepsi korpus luteum menjadi korpus luteum graviditatum dan bila taka da konsepsi menjadi korpus luteum menstruationum.

Korpus Luteum Menstruatinoum

Masih hidup kurang lebih 8 hari, setelah itu terjadi degenerasi dan menjadi korpus albikans yang berwarna putih. Dengan terbentuknya korpus albikans maka pembentukan hormon estrogen dan progesterone mulai berkurang malahan berhenti sama sekali. Hal ini mengakibatkan ischemia dan necrose endometrium yang kemudian disusul dengan menstruasi.

Korpus luteum graviditatum

Bila terjadi konsepsi sel telur yang telah dibuahi tersebut berjalan ke kavum uteri dan sesampainya di dalam kavum uteri menanamkan diri didalam endometrium atau niidasi. Sel telur yang telah dibuahi 
(zygot) mengeluarkan hormon-hormon sehingga korpus albikan tetap tumbuh menjadi lebih besar dan disebut korpus luteum graviditatum yang tetap hidup sampai bulan ke-4 kehamilan, setelah itu faalnya digantikan oleh plasenta. Karena korpus luteum tidak mati,maka progesterone dan estrogen terus terbentuk dengan demikian endometrium tidak nekrosis tetapi malah tumbuh menjadi tebal dan berubah menjadi decidua. Hal inilah yang menyebabkan seorang wanita tidak haid selama kehamilan berlangsung.

\section{KONSEPSI}

Suatu proses kehamilan akan terjadi bila empat aspek penting terpenuhi yaitu ovum, sperma, konsepsi dan nidasi. Kehamilan adalah pertumbuhan dan perkembangan janin intrauterine mulai sejak konsepsi sampai permulaan persalinan.

Setiap bulan wanita melepaskan satu sampai dua telur dari individu telur (ovulasi) yang ditangkap oleh umbai-umbai (fimbriae) dan masuk kedalam sel telur. Waktu persetubuhan cairan semen tumpah kedalam vagina dan berjuta-juta sel mani (sperma) bergerak memasuki rongga Rahim lalu masuk ke sel telur. Pembuahan sel telur oleh sperma terjadi di bagian yang mengembang dari tuba fallopi. Pada sekeliling sel telur banyak berkumpul sperma yang mengeluarkan ragi untuk mencairkan zat yang melindungi ovum kemudian bersatu dengan sel telur. Proses ini disebut dengan fertilisasi atau konsepsi.

Ovum yang telah dibuahi ini segera membela diri sambil bergerak oleh rambut getar tuba menuju ruang Rahim kemudian melekat pada mukosa Rahim untuk selanjutnya bersarang di ruang Rahim. Peristiwa 
ini disebut dengan nidasi (implantasi). Untuk menyuplai darah dan zatzat makanan bagi mudigah dan janin di persiapkan uri (plasenta). Jadi dapat dikatakan bahwa untuk setiap kehamilan harus ada ovum (sel telur), spermatozoa (sel mani), pembuahan (konsepsi),nidasi dan plasenta.

\section{Ovum dan Sperma}

a. Ovum

Ovum atau sel telur adalah suatu sel besar dengan diameter sekitar $0,1 \mathrm{~mm}$. ovum terdiri dari satu nucleus yang terapung-apung dalam vitelus, dilingkari oleh zona pellusida dan dilapisi korona radiate.

1) Proses pertumbuhan ovum (oogenesis)

2) Dengan pengaruh FSH, folikel primer mengalami perubahan menjadi folikel de graf yang menuju permukaan ovarium disertai pembentukan cairan liquor folikuli.

3) Desakan folikuli de Graff ke permukaan ovarium menyebabkan penipisan dan disertai devaskularisasi

4) Selama pertumbuhan menjadi folikel de Graff, ovarium mengeluarkan hormone estrogen yang dapat mempengaruhi :

- Gerak dari tuba semakain mendekati ovarium

- Gerak sel rambut tuba makin tinggi

- Peristaltic tuba makin aktif

5) Dengan pengaruh LH yang semakin besar dan fluktuasi yang mendadak terjadi proses ovum yang disebut ovulasi

6) Dengan gerak aktif tuba yang mempunyai rumbai (fimbriae),ovum yang telah dilepaskan segera ditangkap oleh 
fimbriae tuba. Proses penangkapan ini disebut ovum picup mechanism

7) Ovum yang tertangkat terus berjalan mengikuti tuba menuju uterus, dalam bentuk pematangan pertama (siap dibuahi).

b. Sperma

Proses pembentukan spermatozoa merupakan proses yang kompleks yaitu :

1) Spermatogonium berasal dari sel primitive tubulus

2) Menjadi spermatosit pertama

3) Menjadi spermatist kedua

4) Menjadi spermatit

5) Dan akhirnya menjadi spermatozoa

Pertumbuhan spermatozoa di pengaruhi oleh mata rantai hormone yang kompleks pancaindra, hipotalamus, hipofisis dan sel inertitial leydig sehingga spermatogonium dapat mengalami proses mitosis. Spermatozoa berbentuk seperti kecebong, terbagi menjadi tiga bagian yaitu kepala, ekor dan leher. Bagian kepala berbentuk lonjong agak gepeng dan mengandung nucleus dan berjuta-juta sel sperma. Bagian ekor berfungsi untuk bergerak maju dan bagian leher berbentuk silindrik sebagai penghubung kepala dan ekor. Sel sperma mempunyai kecepatan yang cukup tinggi sehingga dalam satu jam sel sperma sudah sampai di tuba melalui kanalis dan kavum uteri. Disini sel sperma menunggu kedatangan sel telur. Pada hubungan seksual di tumpahkan sekitar 3 cc sperma yang mengandung 0-60 juta spermatozoa setiap cc. Sebagian besar 
spermatozoa mengalami kematian dan hanya beberapa ratus yang dapat mencapai tuba fallopi. Spermatozoa yang masuk ke alat genitalia perempuan mampu hidup selama tiga hari sehingga cukup waktu untuk mengadakan konsepsi.

\section{Oogenesis (wanita)}

Pertumbuhan embrional oogonium yang kelak menjadi ovum terjadi digenital ridge. Menurut umur wanita jumlah oogonium adalah sebagai berikut :

1. BBl $=750.000$

2. Umur 6-15 tahun $=439.000$

3. Umur $16-25$ tahun $=159.000$

4. Umur 26-35 tahun $=59.000$

5. Umur 35-45 tahun $=39.000$

6. Masa menopause = semua hilang

Urutan pertumbuhan ovum (oogenesis) adalah sebagai berikut :

1. Oogonia

2. Oosit pertama (primary oocyte)

3. Folikel ovarium primer (primary ovarian follicle)

4. Liquar folliculi

5. Pematangan pertama ovum

6. Pematangan kedua ovum pada waktu sperma membuahi ovum

Pada wanita, setelah tiba di gonad sel benih primordial segera berdiferensiasi menjadi oogonium. Oogonium kemudian mengalami beberapa kali mitosis dan pada akhir perkembangan embrional bulan ketiga setiap oogonium dikelilingi oleh selapis sel epitel yang berasal 
dari permukaan jaringan gonad, yang nantinya menjadi sel folikuler. Sebagaian besar oogonium terus mengalami mitosis sedangkan sebagian lain berdiferensiasi dan tumbuh membesar menjadi oosit primer. Oosit primer kemudian mengadakan replikasi DNA dan memasuki proses meiosis pertama sampai tahap profase.

Pada bulan ke-5 sampai ke-7 jumlah oogonium diperkirakan mencapai 5-7 juta sel. Pada saat itu, sel-sel mulai berdegenerasi sehingga banyak oogonium dan oosit primer berhenti tumbuh dan menjadi atretik. Akan tetapi,oosit primer yang telah memasuki tahap profase miosis pertama tetap bertahan pada stadiumnya dengan dilapisi sel folikuler epitel gepeng (selanjutnya oosit primer dengan sel folikuler ini disebut sebagai folikel primordial). Folikel primordial tetap pada stadiumnya disebut fase istrahat/fase diktioten sampai sesudah kelahiran dan menjelang pubertas. Jumlahnya pada saat kelahiran sekitar 700 ribu -2 juta folikel.

Pada masa pubertas, sambil mulai terbentuknya siklus menstruasi folikel primordial/oosit primer mulai melanjutkan pematangannya dengan kecepatan yang berbeda-beda. Ovulasi dari suatu siklus haid noral adalah sekitar 2 minggu sebelum terjadinya perdarahan haid berikutnya, hanya 1 sel folikel yang mengalami pematangan sampai tingkat lanjut dan keluar sebagai ovum yang dibuahi.

Pertumbuhan/pematangan diawali dengan pertambahan ukuran oosit primer /folikel primordial menjadi membesar dan sel epitel selapis gepeng berubah menjadi kuboid dan berlapis-lapis. Pada tingkat pertumbuhan ini,oosit primer bersama lapisan epitelnya 
disebut berbeda dan stadium folikel primer. Awalnya oosit primer berhubungan erat dengan sel folikuler kuboid yang melapisinya, namun selanjutnya terbentuk suatu lapisan mukopolisakarida yang membatasi/memisahkan di antaranya, yang disebut zona pellusida. Kemudian terbentuk juga suatu rongga dalam lapisan folikuler (antrum folikuli) yang makin lama makin besar. Akan tetapi sel-sel folikuler yang berbatasan dengan zona pelusida oosit primer tetap utuh dan menjadi cumulus oophorus. Stadium perkembangan ini disebut stadium folikel sekunder.

Kemudian antrum folikel semakin membesar, sementara bagian tepi luar lapisan folikuler mulai di lapisi oleh dua lapisan jaringan ikat yaitu theca interna (lapisan seluler, sebelah dalam yang kemudian menghasilkan hormone estrogen) dan theca eksterna (lapisan fibrosa, sebelah luar).

Pada stadium ini, folikel berada dalam stadium sudah matang disebut sebagai folikel tersier atau folikel de Graff . Setelah tercapai pematangan folikel, oosit primer memasuki pembelahan miosis ke dua dengan menghasilkan dua sel anak yang masing-masing mengandung jumlah DNA sebanyak separuh sel induk (23 tunggal). Akan tetapi hanya satu sel yang tumbuh menjadi oosit sekunder sementara anak lainnya hanya menjadi badan kutub (polar body) yang tidak tumbuh lebih lanjut.

Pada saat oosit sekunder mencapai stadium pembentukan kumparan (coiling) terjadilah ovulasi dimana oosit tersebut dilepaskan dari folikel de Graaf, bersama dengan lapisan cumulus 
oophorus dari folikular dan lapisan zona pellusida. Susunan cumulus oophorus di sekeliling zona pellusid menjadi corona radiate.

Folikel bekas tempat oosit kemudian di bawah pengaruh hormone LH hipofisis akan menjadi korpus luteum yang kemudian menghasilkan hormone progesterone. Kemudian oleh gerakan kontraski dinding tuba dan ayunan serabut-serabut fimbriae dinding tuba, oosit tersebut ikut terbawa kea rah uterus. Didalam tuba inilah terdapat kemungkinan terjadinya pembuahan dengan sel sperma.

Jika terjadi pembuahan,oosit sekunder menyelesaikan stadium pembelahan dan pematangan sampai keduanya menjadi oosit matang serta kemungkinan menghasilkan satu buah polar body lagi. Sementara itu polar body hasil pembelahan sebelumnya diperkirakan juga mengadakan satu pembelahan lagi.

Jika terjadi pembuahan dan kehamilan, korpus luteum aktif karena hormone progesterone yang dihasilkannya berfungsi mempertahankan keseimbangan hormonal selama masa-masa awal kehamilan. Jika tidak terjadi pembuahan,oosit sekunder akan mengalami degenerasi dalam waktu sekitar 24-48 jam pasca ovulasi. Jika tidak terjadi pembuahan dan kehamilan sampai dengan 9-10 hari sesudah ovulasi,korpus luteum akan berdegenerasi dan mengalami fibriosis menjadi korpus albikans. Akibat degenerasi ini produksi progesterone juga menurun menjadi stimulasi untuk terjadinya perdarahan menstruasi berikutnya. Hasil akhir oogenesis normal kemungkinan adalah satu buah oosit matang dan 1-3 buah polar body. Kromosom yang dikandung oleh oosit adalah separuh dari induknya yaitu $23+\mathrm{X}$. 


\section{Fertilisasi dan Implantasi}

Peristiwa bertemunya sperma dan ovum umunya terjadi diampula tuba. Pada hari 11-14 dalam siklus menstruasi, perempuan mengalami ovulasi, peristiwa matangnya sel telur sehingga siap dibuahi. Pada saat fertilisasi terjadi spermatozoa dapat melintasi zona pellusida dan masuk ke vitelus. Ovum yang tidak memiliki daya penggerak, digerakkan oleh silia dan peristaltic kontraksi otot tuba. Pada saat ini serviks dipengaruhi oleh estrogen mensekresi aliran mucus asam yang menarik spermatozoa. Saat berhubungan sekitar 300 juta sperma tersimpan pada forniks vagina. Sperma yang mencapai mucus serviks akan bertahan hidup lalu mendorong diri sendiri maju ke tuba uterin, sementara sisanya dihancurkan oleh media asam vagina. Lebih banyak yang mati dalam perjalanan disepanjang uterus dan hanya seribu yang mampu mencapai tuba dan bertemu dengan ovum. Hanya pada perjalanan inilah sperma akhirnya matang dan mampu melepaskan enzim hialuronidase yang memungkinkan terjadinya penetrasi terhadap zona pellusida serta membrane sel di sekitar ovum. Banyak sperma dibutuhkan pada masa ini, namun hanya satu yang bisa memasuki ovum. Setelahnya membrane di tutup untuk mencegah masuknya sperma yang lain dan inti dari sel ini bersatu. Sperma dan ovum masing-masing menyumbangkan setengah dari kromosom untuk membuatnya berjumlah 47. Sperma dan ovum yang dibuahi disebut zigot. Baik sperma maupun ovum tidak dapat bertahan lebih dari 2 sampai 3 hari dan pembuahan terjadi bila hubungan seksual dilakukan 48 jam 
sebelum atau 24 jam setelah masa ovulasi. Selanjutnya konsepsi akan berlangsung selama 14 hari sebelum menstruasi berikutnya.

\section{Implantasi / nidasi}

Nidasi adalah masuknya atau tertanamnya hasil konsepsi ke dalam endometrium. Blastula diselubungi oleh suatu sampai yang disebut trofoblast, yang mampu menghancurkan dan mencairkan jaringan. Ketika blastula mencapai rongga Rahim, jaringan endometrium berada dalam masa sekresi. Jaringan endometrium ini banyak mengandung sel-sel desidua yaitu sel-sel besar yang mengandung banyak glikogen, serta mudah dihancurkan oleh trofoblast. Blastula dengan bagian yang berisi massa sel dalam (inner cell mass) akan mudah masuk ke dalam desidua menyebabkan luka kecil yang kemudian sembuh dan menutup lagi.

Itulah sebabnya terkadang pada saat nidasi terjadi sedikit perdarahan akibat luka desidua (tanda Hartman). Umunya nidasi terjadi pada depan atau belakang Rahim (korpus) dekat fundus uteri. Bila nidasi telaj tejadi dimulailah diferensiasi sel-sel blastula. Sel lebih keci yang terletak dekat ruang exocoeloma membentuk entoderm dan yolk sac. Sedangkan sel -sel yang tumbuh besar menjadi entoderm dan membentuk tuang amnion. Kemudian terbentuklah suatu lempeng embriona(embrional plate) diantara amnio dan yolk sac.

\section{Plasentasi}

Pertumbuhan dan perkembangan desidua sejak terjadi konsepsi karena pengaruh hormon terus tumbuh sehingga makin lama menjadi tebal. Desidua adalah mukosa Rahim pada kehamilan yang terbatas atas : 
a. Desidua basalis

Terletak diantara hasil konsepsi dan dinding Rahim, disini plasenta terbentuk

b. Desidua Kapsularis

Meliputi hasil konsepsi kea rah rongga Rahim yang lama kelamaan bersatu dengan desidua vera karena obliterasi

c. Desidua Vera (Parietalis)

Meliputi lapisan dalam dinding Rahim lainnya ( Rustam Mochtar,1998:21)

\section{E. PERTUMBUHAN DAN PERKEMBANGAN KONSEPSI}

\section{Pertumbuhan dan perkembangan embrio}

Pertumbuhan dan perkembangan janin dimulai sejak terjadinya konsepsi atau fertilisasi. Perkembangan janin sejak konsepsi hingga saat bayi lahir terbagi dalam tiga periode, yaitu

\section{a. Periode pre embrio (minggu 1-3)}

Periode ini dimulai dari peristiwa konsepsi sampai terjadinya perubahan menjadi embrio.

1) Minggu ke-1

Pertumbuhan dan perkembangan janin pada minggu I, dimulai oleh adanya konsepsi atau fertilisasi. Perkembangan selanjutnya, zigot atau hasil konsepsi mengalami pembelahan dan akhirnya bernidasi di endometrium yang telah disiapkan.

2) Minggu ke-2

Setelah implantasi, terjadi perubahan pada bintik benih yang merupakan bagian blastokist terlihat adanya ruangan amnion dan 
yolk sac. Ruangan ini kelak menjadi besar dan meliputi seluruh embrio, didalam ruang inilah embrio akan tumbuh. Sel-sel yang membatasi ruangan ini dinamakan ectoderm. Pada waktu yang sama, timbul sebuah rongga lain dibawah ruangan amnion yaitu ruang kuning telur. Sel-sel di sekitar ruang kuning telur disebut endoderm. Selanjutnya timbul lapisan lain diantara ectoderm dan endoderm yaitu mesoderm. Endoderm menjadi lebih tebal dan membentuk procordal plate.

Akibat pengaruh hormone estrogen dan progesterone, endometrium terus tumbuh dan menjadi tebal lebih besar dan pembuluh darah menjadi lebih besar. Endometrium yang berubah karena pengaruh kehamilan dinamakan desidua. Ini terjadi kira-kira pada hari ke 14.

Desidua tebagi dalam tiga lapisan yaitu sebagai berikut :

a) Stratum compacta yang sifatnya padat, telur terdapat di dalam lapisan ini

b) Stratum spongiosom, stratum ini mengandung banyak kelenjar dan pemmbuluh darah yang melebar sehingga terjadi perubahan pada penampung menjadi berlubang-lubang menyerupai spon.

c) Startum basale, stratum ini tidak mengalami perubahan.

Selama kehamilan, telur yang bersarang di dalam desidua makin lama makin membesar dan pada saat suatu waktu menonjol dalam Rahim. Ini mengakibatkan desidua terbagi lagi menjadi 3 bagian,yaitu : 
a) Desidua basalis yaitu desidua yang terletak diantara telur dan dinding Rahim yang nantinya akan menjadi plasenta.

b) Desidua kapsularis yaitu desidua yang terdapat antara telur dan kavum uteri

c) Desidua vera yaitu desidua sisa yang tidak mengandung blastokist

3). Minggu ke-3

Selama minggu ke tiga, hasil konsepsi tumbuh pesat yaitu berlangsung mulai hari ke 15 sampai dengan 21. Pada masa ini terjadi diferensiasi sel-sel menjadi organ-organ tubuh sederhana, yaitu :

a)Ectoderm

Ectoderm membentuk jaringan tubuh paling luar seperti rambut,kuku,kulit dan system saraf seperti otak, sum-sum tulang belakang dan saraf motoric. Sel-sel saraf pada saat lahir berjumlah kurang lebih 100 juta. Selama kehidupan manusia, sel-sel baru tidak bertambah tetapi membesar sesuai pertumbuhan tubuh.

b)Mesoderm

Sel-sel mesoderm akan membentuk otot, tulang, jaringan ikat, otot jantung, jantung, pembuluh darah dan corpus, limfa, ginjal dan genetalia.

c)Endoderm

Endoderm membentuk organ-organ tubuh bagian dalam seperti interstinum, parathyroid, tyroid, thymus, liver, pancreas, tarctus respiratoirs, saluran paringotimpani dan telinga tengah, 
kandung kencing, uretra, genitalia, laki-laki dan perempuan, kelenjar prostat, kelenjar vestibulum dan garis uterus. Pembentukan genitalia dan system urinarius dimulai dari penonjolan dan penebalan mesoderm yang disebut urogenital ridge, dilanjutkan dengan migrasi sel-sel germinativum primordial dari dinding yolk sac dekat vertikulum allantois.

\section{b. Periode embrio (minggu 4-8)}

Periode ini ditandai dengan pertumbuhan diferesiansi dan pembentukan organ-organ besar. Semua organ-organ eksternal dan internal dibentuk (organogenesis). Embrio berubah menjadi bentuk janin dalam periode 8 minggu (morphogenesis).

1) Minggu ke-4

Selama 4 minggu embrio tumbuh dan bertambah panjang 3,5 $\mathrm{cm}$ dan berat kira-kira $5 \mathrm{mg}$. Perpanjangan embrio kearah atas kepala, kearah bawah menjadi ekor dan ke arah samping menjadi tubula. Penutupan saluran pernafasan mulai terjadi di daerah atas bawah oksiput. Pericardial jantung membesar karena mengangkatnya kepala, pertumbuhan laringotracheal dan paru-paru menjadi system pernapasan. Mandibulla dan maxilla menjadi rahang yang terpisah, mata,telinga dan hidung menjadi terpisah. System peredaraan darah sederhana mulai terbentuk dan jantung mulai berdetak, lambung, liver dan pancreas, tyroid dan kelenjar thymus mulai berkembang placenta tumbuh sempurna. 
2) Minggu ke -5

Pada pertengahan kehamilan, janin di ukur dengan ukuran kepala bokong (CRL). Sebelum pertengahan kehamilan janin diukur dengan ukuran bokong tumit (CHL). Panjang CRL dari $4 \mathrm{~mm}$ menjadi $8 \mathrm{~mm}$ dan beratnya dari $5 \mathrm{mg}$ menjadi $50 \mathrm{mg}$. Pertumbuhan kepala lebih cepat dari pertumbuhan badan, sehingga embrio melengkung dan membentuk huruf $\mathrm{C}$. permulaan bentuk kaki dan tangan berupa benjolan.

3) Minggu ke-6

Kepala terlihat lebih besar dari leher dan melengkung melampaui jantung. Posisi mata,hidung dan mulut jelas. Kaki atas dan bawah mulai dapat diidentifikasi dan telapak tangan berkembang menjadi jari-jari.

4) Minggu ke-7

Jantung sudah terbentuk lengkap. Saraf dan otot bekerja bersamaan untuk pertama kalinya. Bayi mempunyai reflex dan bergerak spontan. Bayi mulai menendang dan berenang di dalam Rahim walau ibu belum mampu merasakannya. Pada akhir minggu ini, otak akan terbentuk lengkap. Dalam minggu ketujuh dan selama minggu kedelapan,otot-otot menempati posisinya di sekililing bentukan tulang.

5) Minggu ke-8

Pertumbuhan dan diferensiasi somit begitu cepat sampai dengan akhir minggu ke-8 terbentuk 30-35 somit, disertai dengan perkembangan berbagai karakteristik fisik lainnya seperti jantungnya mulai memompa darah. Anggota badan 
terbentuk dengan baik. Perut muka dan bagian utama otak dapat dilihat . telingan terbentuk dari lipatan kulit tulang dan otot yang kecil terbentuk di bawah kulit.

\section{c. Periode janin (minggu 9-40)}

Periode ini ditandai dengan pertumbuhan dan perkembangan organ-organ besar tubuh dan diferensiasi system organ, dimana organisme yang telah memiliki struktur lengkap melanjutkan pertumbuhan dan perkembangan yang pesat sampai pada keadaan yang memungkinkan untuk hidup dan berfungsi di dnia luar (ekstra uterine).

1)Minggu ke 9-12

Pada usia 9 minggu kepala terlihat lebih besar,wajah tampak secara garis besar, perbandingan ukuran tungkai atas sudah mencapai proporsi normal. Tungkai bawah berkembang lebih panjang. Genitalia eksterna perempuan dan laki-laki terliat sama pada minggu ke-9 tetapi mencapai maturitas sempurna dan dapat dibedakan pada minggu ke-12. Sel-sel darah merah mulai di produksi oleh liver selama minggu awal dan fungsinya diambil alih olej splenn selama minggu ke-12. Panjang janin sekitar 7-9 cm

2)Minggu ke-13-16

Pada bulan-bulan ini janin tumbuh pesat panjangnya menjadi dua kali lipat. Kepala merupakan bagian utama. Posisi mata dan telinga menjadi lebih inferior. Kulit dibagian kepala mulai ditumbuhi rambut halus (lanugo). Kaki lebih panjang dan otot tumbuh dengan cepat. Keadaan ini dapat dilihat melalui rongten 
pada usia 16 minggu. Janin sudah menyerupai manusia, mandibular menjadi dagu dan telinga lebih tinggi diatas kepala. Pada saat ini plasenta sudah terbentuk sempurna. Panjang janin sekitar $10-17 \mathrm{~cm}$ beratnya 105 gram.

3)Minggu ke 17-20

Janin tumbuh lambat. Tubuh penuh dengan lanugo dan kelenjar sebacea. Kelenjar lemak verniks caseosa mulai dibentuk, verniks caseosa menutupi kulit dan melindungi janin dari trauma suhu. Pergerakan janin pertama mulai dirasakan oleh ibu pada masa kehamilan 16-20 minggu. Denyut jantung janin dapat didengar untuk pertama kalinya dengan dopler. Pada usia 20 minggu, kehidupan janin sangat tergantung pada lingkaran uterus. Akhir minggu ke-20 panjang janin 18-27 cm dan beratnya 310 gram.

4)Minggu 21-23

Pada masa ini, janin kurus namun beratnya tetap. Kulit berwarna merah dan berkeriput karena tertutup verniks caseosa. Paru-paru mulai berkembang dan memproduksi surfaktan. Meconium mulai menimbun dan mencapai rectum. Akhir periode panjang janin 28-34 cm dan beratnya 60 gram.

5)Minggu ke-2-27

Kulit janin tumbuh pesat, terlihat berkerut lemak sub kutan, pembuluh darah menutup dan memberi warna merah. Muka menjadi sempurna, bulu mata dan kening dibentuk dan kelopak mata terbuka. Akhir periode panjang janin 35-38 cm dan beratya 1080 gram, 
6)Minggu ke 28-31

Permukaan kulit penuh dengan lemak sub cutan, janin dapat dilahirkan walaupun fungsi pernapasan belum matang. Akhir periode panjang janin $2,5 \mathrm{~cm}$ beratnya 1670 gram.

7)Minggu ke 32-36

Pada kehamilan delapan bulan permukaan kulit mulai merah dan keriput seperti kulit orang tua. Lanugo tidak tumbuh di wajah tetapi pada kepala. Verniks caseosa lebih tebal dan melindungi kulit, jari kuku tumbuh sempurna. Dengan perawatan yang baik, janin mampu hidup di luar uterus. Akhir periode panjang janin $46 \mathrm{~cm}$ dan beratnya 2400 gram

8)Minggu ke 37-39

Janin tumbuh lebih gemuk karena cepatnya pembentukan jaringan lemak. Pada janin laki-laki testis turun menuju scrotum, janin sudah dapat hidup lebih baik.

9)Minggu ke 40

Pada usia 40 minggu janin berkembang sempurna. Kuku jari tangan dan kaki tumbuh sempurna melampui ujung jari, testis janin laki-laki sudah turun kedalam skrotum. Panjang janin 50 cm dan beratnya 3000 gram.

\section{Struktur dan Fungsi Amnion}

a. Struktur amnion

Ruangan amnion berisi satu liter air ketuban. Air ketuban sebagian besar mengandung air, tetapi juga mengandung sedikit ureum, asam urin, protein,gula, garam serta enzim. Bila diendapkan air 
ketuban mengandung lanugo, verniks kaseosa yang berasal dari kulit tubuh janin dan sel-sel.

b.Fungsi amnion

1. Melindungi janin dari rudapaksa tumpul

2. Menjaga agar tali pusat mudah tertekan

3. Menjaga agar janin dapat tumbuh bebas kesegala jurusan sehingga pertumbuhannya tidak terganggu

4. Menjaga agar tidak timbul perlekatan antara amnion dan janin

5. Menjaga keseiabangan suhu uterus

6. Menjaga uterus dari infeksi

7. Membuat jalan lahir bersih dan licin pada saat partus.

Berikut ini adalah karakteristik cairan amnion dalam keadaan normal:

○ Pada usia kehamilan cukup,volume 1000-1500 cc

○ Keadaan jernih agak keruh

$\circ$ Steril

○ Bau khas,agak manis dan amis

o Terdiri atas $98-99 \%$ airy, 1-2\% garam-garam anorganik dan bahan organic (protein terutama albumin), runtuhan rambut lanugo, veniks caseosa dan sel-sel epitel

o Sirkulasi sekitar $500 \mathrm{cc} / \mathrm{jam}$

Beberapa kelainan jumlah cairan amnion adalah sebagai berikut :

1.Hidroamnion (polihidroamnion) yatiu air ketuban berlebihan duatas 2000 cc. Dapat mengarahkan kecurigaan adanya kelainan kongenital susunan saraf pusat, system pencernaan,gangguan sirkulasi atau hiperaktivitas system urinarius janin 
2. Oligohidroamnion yaitu air ketuban sedikit dibawah 500 cc. umumnya kental,keruh dan berwarna kuning kehijauan. Prognosis buruk bagi janin.

\section{c. Struktur fungsi dan sirkulasi tali pusat}

a. Struktur tali pusat

Tali pusat merentang dari pusat janin ke plasenta bagian janin. Panjangnya rata-rata $50-55 \mathrm{~cm}$, diameter 1-2,5 cm (sebesar jari). Pernah dijumpai tali pusat terpendek $0,5 \mathrm{~cm}$ terpanjang $200 \mathrm{~cm}$. tali pusat terdiri dari 2 arteri umbilikalis dan 1 vena umbilikalis serta jelly wharton

b. Fungsi tali pusat

1. Media transportasi nutrisi dan oksigen dari plasenta ke tubuh janin

2. Media transportasi untuk mengeluarkan sisa metabolisme janin ke tubuh

3. Media transportasi zat antibody dari ibu ke janin.

c. Sirkulasi tali pusat

Kedua arteri dan satu vena yang berada dalam tali pusat menghubungkan system kardiovaskuler janin dengan plasenta.

\section{d.Struktur Fungsi dan Sirkulasi Plasenta}

a. Struktur plasenta

Bentuk plasenta matur adalah bulat datar dengan diameter sekitar $20 \mathrm{~cm}$ dan tebal 2,5 cm serta beratnya sekitar 500-600 gram.

Plasenta mempunyai dua bagian, yaitu :

1. Permukaan maternal 
Darah maternal mengakibatkan permukaan ini berwarna merah tua dan memisahkan sebagian dari desidua basal. Permukaan ini terbagi atas 20 lobus yang dipisahkan oleh sulkus (terowongan), tempat desidua masuk ke bawahnya dan membentuk dinding. Lobus terbuat dari lobules yang masingmasing terdiri atas satu vilus dan cabang-cabangnya. Kadangkala kumpulan garam kalsium oksida terdapat pada permukaan ini, membuatnya seidikit berpasir. Ini tidak menandakan kondisi klinis yang signifikan.

\section{Permukaan fetal}

Amnion melapisi permukaan janin sehingga berwarna putih dan mengkilat. Cabang-cabang dari vena dan arteri umbilical dapat dilihat yang normalnya terletak ditengah. Amnion bisa lepas dari permukaan, terlepas dari lapisan korionik tempat perkembangan plasenta bersama korion. Plasenta terbentuk pada minggu ke 16 dimana desidua parietalis dan desia kapsularis menjadi satu. Sebelum plasenta terbentuk sempurna dan sanggup memelihara janin, fungsinya dilakukan oleh korpus luteum gravidarum. Saat nidasi, vili korioalis mengeluarkan hormone korionik gonadotropin sehingga korpus luteum mampu bertahan

b.Fungsi Plasenta

1. Respirasi yaitu memberikan oksigen dan mengeluarkan karbon dioksida janin

2. Nutrisi yaitu memberikan bahan makanan pada janin

3. Eksresi yaitu mengalirkan keluar sisa metabolism janin 
4. Endokrin yaitu menghasilkan hormone-hormon HCG, HPL, estrogen, progesterone

5. Imunologi yaitu menyalurkan berbagai komponen antibiodi ke janin

6. Farmakologi yaitu menyalurkan obat-obatan yang mungkin diperlukan janin yang diberikan melalui ibu

7. Proteksi, barrier terhadap infeksi bakteri, virus dan zat-zat toksik teapi akhir-akhir ini di ragukan karena pada kenyataannya janin sangat mudah terpapar infeksi/intoksikasi yang dialami ibunya)

c. Sirkulasi Plasenta

Implantasi plasenta terjadi pada fundus uteri depan atau belakang. Fungsi plasenta dapat dilaksanakan melalui sirkulasi retroplasenta dengan terbentuknya arteri spiralis dan vena di dasar desidua basalis. Dibagian tepi plasenta terdapat ruangan agak lebar sebagai penampung sementara darah sebelum masuk menuju sirkulasi darah ibu. Sirkulasi retroplasenter terjadi karena aliran darah arteri spinalis memiliki tekanan 70-80 mmHG sedangkan tekanan darah pada vena di dasar desidua basalis adalah 20-30 mmHg . Aliran darah arteri seolah-olah tegak lurus untuk mencapai plat korionik di bagian palsenta fetalis dalam ruangan intervili. Dengan adanya perbedaan tekanan terjadi aliran darah yang memberikan kesempatan luas bagi vili karioalis bergerak-gerak karena aliran darah ibu dan terjadinya kontraski ringan memberikan peluang untuk makin sempurnanya pertukaran nutrisi. 


\section{e. Sirkulasi darah Fetus}

System peredaraan darah fetus berbeda dengan system peredaraan darah orang dewasa karena paru-paru fetus belum berkembang sehingga $\mathrm{O}_{2}$ diambil melalui perantaraan plasenta. Oleh karena itu,system peredaraan darah fetus ditentukan oleh factor-faktor dibawah ini, yaitu :

a. Foramen ovale antara kedua atrium

b. Duktus arteriosus Bothali antara arteri pulmonalis aorta

c. Duktus venosus arantii di dalam hepar menuju vera kaca inferior

d. Pada umbilikalis terdapat satu vena umbilikalis dan dua arteri umbilikalis

\section{Peredaraan darah fetus berlangsung sebagai berikut :}

a. Darah yang kaya dengan nutrisi dan oksigen dialirkan melalui vena umbilikalis sebagian kecil menuju melewati vena hepatica dan sebagian besar menuju atrium kanan melalui vena kava inferior melewati duktus venosus arantii.

b.Dari atrium kanan janin sebagian besar darah masuk ke atrium kiri melalui foramen ovale.

c. Sebagian kecil darah dari atrium kanan masuk ke ventrikel kanan

d.Darah yang masuk ke atrium kiri akan di pompa masuk ke aorta dan selanjutnya dialirkan ke seluruh tubuh janin

e. Cabang aorta dibagian bawah menjadi dua arteri hipogastrika unterna yang mempnyai cabang arteri umbilikalis.

f. Darah dari ventrikel kanan di pompa menuju paru-paru tetapi karena paru-paru belum berkembang, darah yang terdapat pada 
arteri pulmonalis dialirkan menuju aorta melalui duktus arteriosus Bothali.

g.Darah yang dialirkan menuju paru-paru akan dialirkan kembali menuju jantung melalui vena pulmonalis.

h.Darah yang menuju plasenta melali arteri umbiliklis terpecah menjadi kapiler untuk mendapatkan nutrisi dan $\mathrm{O}_{2}$ untuk pertumbuhan dan perkembangan janin.

i. Sisa metabolism janin dan $\mathrm{CO} 2$ dilepaskan ke dalam sirkulasi retroplasenter untuk selanjutnya dibuang melalui alat pembuangan yang terdapat di tubuh ibu.

Perdaraaan darah janin berlangsung selama kehidupan intra uterine, dimana plasenta memegang peranan yang sangat penting. Kegagalan fungsi dapat menimbulkan berbagai penyulit dalam pertumbuhan dan perkembangan janin.

Factor penting yang mengubah peredaraan darah janin menuju peredaraan dewasa ditentukan oleh :

1. Berkembangnya paru-paru janin

Berkembangnya paru menyebabkan adanya tekanan negative dalam paru sehingga dapat menampung darah, untuk melakukan pertukaran $\mathrm{CO} 2$ dan $\mathrm{O} 2$ dari udara. Dengan demikian duktus arteosus Bothali tidak berfungsi dan akan mengalami obliterasi. Tekanan didalam atrium kiri makin meningkat sehingga bias menutup foramen ovale. Tekanan yang tinggi pada atrium kiri disebabkan oleh darah yang mengalir ke atrium kanan, kini langsung menuju paru-paru dan selanjutnya dialirkan ke atrium kiri 
melalui vena pulmonalis. Dua factor ini menyebabkan tekanan di atrium kiri meningkat.

2. Terputusnya hubungan peredaraan darah antara ibu dan janin dengan dipotongnya tali pusat.

Pemotongan tali pusat sebaiknya dilakukan setelah bayi mennagis dengan nyaring atau tali pusat berhenti berdenyut karena bias menambah darah plasenta sekitar 50-75 ml yang sangat berarti bagi pertumbuhan bayi.

3. Membuat adult haemoglobin (tipe A) sehingga siap melakukan pertukaran $\mathrm{CO} 2$ dan $\mathrm{O} 2$ melalui paru-paru. Menjelang persalinan disiapkan pembuatan adult haemoglobin (A) sehingga setelah lahir langsung dapat menangkap $\mathrm{O} 2$ dan melepaskan $\mathrm{CO} 2$ melalui pernapasan.

\section{F. PERUBAHAN ANATOMI DAN ADAPTASI FISIOLOGI PADA IBU HAMIL TRIMESTER I,II DAN III}

\section{System Reproduksi}

\section{a.Uterus}

\section{Ukuran}

Untuk akomodasi pertumbuhan janin, Rahim membesar akibat hipertrofi dan hiperplasi otot polos Rahim, serabut-serabut kolagennya menjadi higroskopik, endometrium menjadi desidua. Ukuran pada kehamlilan cukup bulan adalah 30x25x20 cm dengan kapasitas lebih dari $4000 \mathrm{cc}$.

\section{Berat}

Berat uterus naik secara luar biasa dari 30 gram menjadi 1000 gram pada akhir kehamilan (40 minggu). 


\section{Bentuk dan konsistensi}

Pada bulan-bulan pertama kehamilan bentuk Rahim seperti buah alpukat/pir. Pada kehamilan empat bulan berbentuk bulat sedangkan pada akhir kehamilan berbentuk bujur telur. Ukuran Rahim kira-kira sebesar telur ayam, pada kehamilan dua bulan sebesar telur bebek, dan kehamilan 3 bulan sebesar telur angsa. Pada minggu pertama isthmus Rahim hipertrofi dan bertambah panjang sehingga bila diraba terasa lebih panjang. Pada kehamilan 5 bulan Rahim teraba seperti berisi cairan ketuban dan dinding Rahim terasa tipis. Hal itu karena bagian-bagian janin dapat diraba melalui dinding perut dan dinding Rahim.

\section{Posisi Rahim}

a. Pada permulaan kehamilan dalam letak antefleksi atau retrofleksi

b. Pada empat bulan kehamilan Rahim tetap berada dalam rongga pelvis

c. Setelah itu mulai memasuki rongga perut yang dalam pembesarannya dapat mencapai batas hati.

d. Rahim yang hamil biasanya mobilitasnya lebih mengisi rongga abdomen kana atau kiri . (Rustam Mohtar)

\section{Vaskularisasi}

Arteri uterin dan arteri ovarika bertambah dalam diameter panjang dan anak-anak cabangnya . pembuluh darah balik (vena) mengembang dan bertambah (Rostam Muchtar).

\section{Gambaran Besarnya Rahim dan Tuanya Kehamilan}

a. Pada kehamilan 16 minggu kavum uteri seluruhnya diisi oleh amnion dimana desidua kapsularis dan desidua vera (parietalis) 
telah menjadi satu. Tinggu fundus uteri terletak antara pertengahan sympisis dan pusat. Plasenta telah terbentuk seluruhnya.

b. Pada kehamilan 20 minggu, tinggi fundus uteri terletak 2-3 jari dibawah pusat

c. Pada kehamilan 24 minggu tinggi fundus uteri terletak setinggi pusat

d.Pada kehamilan 28 minggu tinggi fundus uteri terletak 2-3 jari diatas pusat. Menurut Spiegelberg pada umur kehamilan ini fundus uteri dari sympisis adalah $26,7 \mathrm{~cm}$ dari simpisis.

e. Pada kehamilan 36 minggu TFU terletak 3 jari dibawah prosesus sifoideus (PX)

f. Pada kehamilan 40 minggu TFU terletak sama dengan 8 bulan tetapi melebar kesamping yaitu terletak antara pertengahan pusat dan prosesus sifoideus

\section{Gambaran Tinggi Fundus Uteri (TFU) Dikonversikan dengan Usia Kehamilan (UK)}

- Sebelum minggu 11 fundus belum teraba dari luar.

- $\square$ Minggu 12, 1-2 jari diatas sympisis.

- $\square$ Minggu 16, pertengahan antara sym-pst

- $\square$ Minggu 20, tiga jari dibawah pusat

- $\square$ Minggu 24, setinggi pusat

- $\square$ minggu 28, tiga jari diatas pusat

- $\square$ Minggu 32, pertengahan proc xymphoideus - pusat

- $\square$ Minggu 36, tiga jari dibawah proc.xypoideus

- $\square$ Minggu 40pertengahan antara proc xyphoideus-pusat.

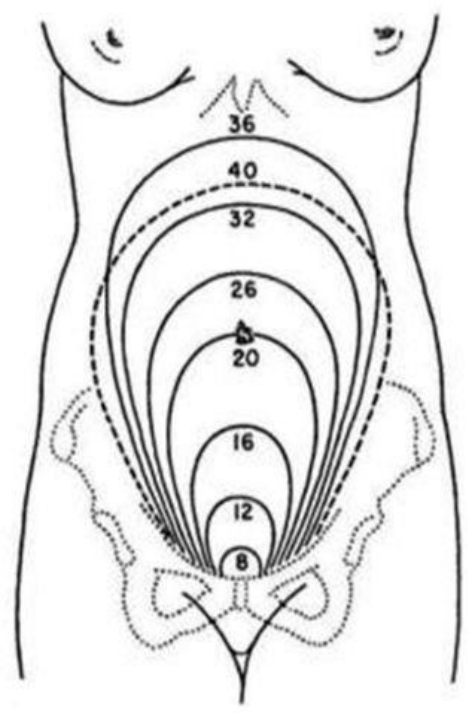




\section{b.Serviks Uteri}

Serviks bertambah vaskularisasinya dan menjadi lunak (s0ft) yang disebut dengan tanda Godell. Kelenjar endoservikal membesar dan mengeluarkan banyak cairan mucus, oleh karena pertambahan dan pelebaran pembuluh darah, warnanya menjadi livid yang disebut tanda Chadwick (Rustam Mochtar).

\section{c. Vagina Dan Vulva}

Vagina dan vulva mengalami perubahan karena pengaruh estrogen. Akibat dari hipervaskularisasi vagina dan vulva terlihat lebih merah atau kebiruan. Warna livid pada vagina dan portio serviks disebut tanda Cadwick.

\section{d.Ovarium}

Saat ovulasi terhenti masih terdapat korpus luteum graviditas sampai terbentuknya plasma yang mengambil alih pengeluaran estrogen dan progesterone (kira-kira pada kehamilan 16 minggu dan kropus luteum graviditas berdiameter kurang lebih $3 \mathrm{~cm}$ ). kadar relaksin disirkulasi maternal dapat ditentukan dengan meningkat dalam trimester pertama. Relaksin mempunyai pengaruh menenangkan hingga pertumbuhan janin menjadi baik hingga aterm.

\section{e. Dinding Perut (Abdominal Wall)}

Pembesaran Rahim menimbulkan peregangan dan menyebabkan robeknya serabut elastis dibawah kulit sehingga timbul striae gravidarum. Kulit perut pada linea alba bertambah pigmentasinya dan disebut linea Nigra. 


\section{f. Payudara}

Selama kehamilan payudara bertambah besar, tegang dan berat. Dapat teraba nodul-nodul akibat hipertrofi bayangan vena-vena lebih membiru. Hiperpigmntasi pada putting susu dan areola payudara. Apabila diperas akan keluar air susu (kolostrum) berawrna kuning.

Perkembangan payudara ini terjadi karena pengaruh hormon saat kehamilan yaitu estrogen,progesterone dan somatomamtropin.

1. Hormon persiapan payudara

Fungsi hormone yang mempersiapkan payudara untuk pemberian ASI antara lain sebagai berikut

a. Estrogen

- Menimbulkan hipertrofi system saluran payudara

- Menimbulkan penimbunan lemak,air serta garam sehingga payudara tampak jadi besar

- Tekanan serat saraf akibat penimbunan lemak,air dan garam menyebabkan rasa sakit pada payudara.

b. Progesterone

- Mempersiapkan asinus sehingga dapat berfungsi

- Menambah sel asisnua

c. Somatomatropin

- Memperngaruhi sel asinus untuk membuat kasein, laktalbumin dari laktoglobulin

- Penimbunan lemak sekitar alveolus payudara

2. Perubahan payudara pada ibu hamil 
a. Payudara menjadi lebih besar

b. Areola payudara makin hitam karena hiperpigmentasi

c. Glandula montgomery tampak menonjol dipermukaan areola mamae

d.Pada kehamilan 12 minggu ke atas dari putting susu akan keluar cairan putih jernih (kolostrum) yang berasal dari kelenjar asinus yang mulai bereaksi.

e. Pengeluaran ASi belum terjadi karena prolactin ini ditekan oleh PIH (Prolaktin Inhibing Hormone)

f. Setelah persalinan dengan dilahirkannya plasenta maka pengaruh estrogen, progesterone dan somatomamotropin terhadap hipotalamus hilang sehingga prolactin dapat dikeluarkan dan laktasi terjadi.

\section{Sistem Endokrin}

Kelenjar endokrin atau kelenjar buntu adalah kelenjar yang mengirimkan hasil sekresinya langsung kedalam darah yang berada dalam jaringan kelenjar tanpa melewati duktus atau saluran dan hasil sekresinya disebut hormone.

a. Kelenjar Hipofisis

Suatu kelenjar endokrin yang terletak didasar tengkorak yang memegang peranan penting dalam sekresi hormone dan semua organ endokrin . kelenjar ini dapat dikatakan sebagai kelenjar pemimpin karena hormone yang dihasilkan dapat mempengaruhi pekerjaan kelenjar lainnya. Kelenjar hipofise terdiri atas dua lobus yaitu lobus anterior dan lobus posterior. Lobus Anterior ( Adenohipofises) menghasilkan sejumlah hormone yang bekerja 
sebagai zat pengendali produksi dan semua organ endokrin yang lain.

\section{1) Hormon Somatotropik}

Mengendalikan pertumbuhan tubuh karena melalui kartilago epifisis pada tulang panjang.

\section{2) Hormon Tirotropik}

Mengendalaikan kegiatan kelenjar tiroid dalam menghasilkan hormon tiroksin.

3) Hormon Prolaktin : juga mempunyai sasaran bukan kelenjar endokrin melainkan kelenjar susu. Pada wanita yang bersalin kelejar susunya di rangsang oleh hoemon prolactin sehingga wanita tersebut menghasilkan air susu untuk bayinya.

\section{4) Hormon Adrenokortiktropik (ACTH)}

Mengendalikan kelenjar suprarenal dalam menghasilkan kortisol yang berasal dari korteks kelenjar suprarenal.

\section{5) Hormon Gonadotropin}

Mempunyai sasaran gonad sebagai kelenjar endokrin. Paling sedikit ada tiga hormon yang termasuk gonadotropin yaitu FSH,LH,Luteo Tropic Hormon (prolactin/LTH). FSH pada wanita merangsang perkembangan sel-sel folikel dalam ovarium untuk berkembang dan menghasilkan hormon wanita. Pada lakilaki,FSH disebut juga interstitial Cell Simulating Hormon (ICSH) yang merangsang sel-sel dalam jaringan testis untuk menghasilkan testosterone. LH mengendalikan sekresi estrogen dan progesterone dalam ovarium dan testosterone dalam testis. 


\section{* Folikel Stimulating Hormone (FSH)}

FSH dalam jumlah besar ditemukan di urine wanita menopause. Selian itu ditemukan juga pada wanita usia 11 tahun dan jumlahnya akan terus bertambah sampai dengan dewasa. FSH dibentuk oleh sel $\beta$ (Basophil) dari lobus anterior hipofisis. Pembentukan FSH ini akan berkurang pada pembentukan dan dan pemberian etrogen dalam jumlah cukup dan pada saat kehamilan. Pengaruh FSH yaitu dapat menimbulkan beberapa folikel primordial yang dapat berkembang dalam ovarium menjadi folikel de Graff yang membuat estrogen (yang menimbulkan proliferasi pada endometrium).

\section{Luteinizing Homone (LH)}

LH banyak ditemukan pada wanita menopause. LH bekerja sama dengan FSH menyebabkan terjadinya sekresi strogen dari folikel De Graff. Selain itu juga menimbulkan penimbunan substansi dari progesterone dalam sel granulosa. Bila estrogen dibentuk dalam jumlah cukup besar maka akan menyebabkan pengurangan $\mathrm{FSH}$, sedangkan produksi LH akan bertambah sehingga tercapai suatu rasio produksi FSh dan LH yang dapat merangsang terjadinya ovulasi. Korpus luteum berkembang dibawah pengaruh LH dan memproduksi estrogen dan progesterone (menyebabkan kelenja-kelenjarnya belekuk-lekuk dan bersekresi). 


\section{b. Hormone Plasenta}

Sekresi hormone plasenta dan HCG dari plasenta janin mengubah organ endokrin secara langsung. Peningkatan kadar estrogen menyebabkan produksi globulin meningkat dan menekan produksi tiroksin, kortikosteroid dan steroid dan akibatnya plasma yang mengandung hormone-hormon ini akan meningkat jumlahnya. Tetapi kadar hormone bebas tidak mengalami peningkatan yang besar.

\section{c. Hipotalamus}

Hipotalamus merupakan bagian dari batang otak sehingga jaringan ini termasuk dalam system saraf otak. Namun sel-sel saraf dalam hipotalamus mampu menghasilkan bahan kimia yang dapat memengaruhi sel-sel kelenjar endokrin. Hipotalamus dapat dianggap sebagai kelenjar endokrin yang hormonnya mempunyai sasaran kelenjar hipofisis. Homon yang dilepas oleh kelenjar hipofisis dinamakan factor pelepasan hormon (releasing factor hormone)

\section{d. Kelenjar Tiroid}

Kelenjar tyroid terdiri atas dua lobus yaitu terletak disebelah kanan dari kiri trakea diikat bersama oleh jaringan tiroid dan melindungi trakea disebelah depan . Kelenjar ini terletak dalam leher dibagian depan,melekat pada dinding laring. Oleh karena pengaruh hormon yang dihasilkan oleh kelenjar hipofisis lobus anterior, kelenjar tiroid ini dapat memproduksi hormon tiroksin. Adapun fungsi dari hormon tiroksin adalah mengatur pertukaran 
zat/metabolism dalam tubuh serta mengatur pertumbuhan jasmani dan rohani.

Untuk membuat hormonnya yaitu tiroksin $\left(\mathrm{T}_{4}\right)$ dan triiodotironin (T3) diperlukan bahan yodium. Dalam setiap molekul tiroksin terdapat empat atom yodium dan dalam setiap molekul triiodotironin terdapat tiga atom yodium.

Struktur kelenjar tiroid terdiri atas sejumlah besar vesikelvesikle yang dibatasi oleh epitelium silinder dan disatukan oleh jaringan ikat. Sel-selnya mengeluarkan cairan yang bersifat lekat yaitu koloidea tiroid yang mengandung zat senyawa yodium dan dinamakan hormon tiroksin. Secret ini mengisi vesikel dan dari sini berjalan ke aliran darah baik langsung maupun melalui saluran limfe.

Fungsi kelenjar tiroid yaitu sebagai berikut :

1.Bekerja sebagai perangsang proses oksidasi

2.Mengatur penggunaan oksidasi.

3. Mengatur pengeluaran karbon dioksida.

4. Metabolic dalam hal pengaturan susuan kimia dalam jaringan

5.Pada anak memengaruhi perkembangan fisik dan mental.

Gipofungsi dapat menyebabkan penyakit kretinismus dan penyakit miksederma sedangkan hiperfungsi menyebabkan penyakit goiter. Sekresi hormon tiroid diatur oleh sebuah hormon dari lobus anterior kelenjar hipofises yaitu hormon tirotropik.

Fungsi kelenjar tiroid sangat erat hubungannya dengan kegiatan metabolic dalam hal pengaturan susunan kimia dan jaringan, bekerja sebagai perangsang proses oksidasi serta 
mengatur penggunaan oksigen dalam mengatur pengeluaran karbon dioksida.

\section{e. Kelenjar Paratiroid}

Terletak di setiap sisi kelenjar yang terdapat didalam leher. Kelenjar ini berjumlah empat buah yang tersusun berpasangan yang menghasilkan parathormon atau hormon paratiroksin. Kelenjar paratiroid berjumlah empat buah masing-masing melekat pada bagian belakang kelenjar tiroid. Kelenjar ini menghasikan hormon yang berfungsi mengatur kadar kalsium dan fosfor di dalam tubuh.

Hipoparatirodisme terjadinya kekurangan kalsium di dalam darah (hipokalsemia) yang dapat mengakibatkan keadaan yang disebut tetani.

Hiperparatirodisme biasanya terdapat pembesaran kelenjar (tumor). Pada keadaaan ini keseimbangan distribusi kalsium terganggu. Kalsium dikeluarkan kembali oleh tulang dan dimasukan kembali keserum darah yang mengakibatkan terjadinya penyakit tulang (osteoporosis).

\section{Fungsi paratiroid adalah sebagai berikut}

1. Mengatur metabolism fosfor

2. Mengatur kadar kalsium darah

Hipofungsi mengakibatkan penyakit tetani. Hipofungsi mengakibatkan kelainan seperti kelemahan otot, sakit pada tulang, kadar kalsium dalam darah meningkat, dekalsifikasi dan deformitas. 


\section{f. Kelenjar Timus}

Terletak di dalam mediastinum dibelakang os sternum. Kelenjar timus hanya dijumpai pada anak-anak di bawah 18 tahun, terletak di dalam toraks kira-kira setinggi bifurkasi trakea, warnanya kemerah-merahan dan terdiri atas 2 lobus. Pada bayi baru lahir ukurannya sangat kecil dan beratna \pm 10 gram atau lebih sedikit. Ukurannya bertambah pada masa remaja menjadi 30-40 gram kemudian mengkerut lagi.

Fungsi hormon yang dikeluarjan oleh kelenjar timus adalah sebagai berikut :

1. Mengaktifkan pertumbuhan badan

2. Mengurangi aktivitas kelenjar kelamin

\section{g. Kelenjar Adrenal/Superadrenalis}

Kelenjar suprarenalis jumlahnya ada dua terdapat pada bagian atas dari ginjal kiri dan kanan dan beratnya rata-rata 5-9 gram.

Kelenjar supraenalis terbagi atas 2 bagian yaitu :

1. Bagian luar yang berwarna kekuningan yang menghasilkan kortisol yang disebut korteks.

2. Bagian medulla yang menghasilkan adrenalis (epinerfin) dan noradrenalin (norepinefrin).

Zat-zat tersebut disekresikan dibawah pengendalian system persarafan simpatis. Sekresinya bertambah dalam keadaan emosi seperti marah dan takut, Serta dalam keadaan asfiksia dan kelaparan. Pengeluaran yang bertambah akan meningkatkan tekanan darah guna melawan syok. Noradrenalin menaikkan tekanan darah dengan jalan merangsang serabut otot di dalam 
dinding pembuluh darah untuk berkontraksi, adrenalin membantu metabolisme karbohidraat dengan jalan menambah pengeluaran glukosa dari hati. Beberapa hormon yang disekresikan oleh korteks adrenal yaitu hidrokortison,aldosterone dan kortikosteroid. Fungsi kelenjar adrenal bagian korteks adalah sebagai berikut :

1. Mengeatur keseimbangan air, elektrolit dan garam-garam

2. Mengatur/memengaruhi metabolism lemak, karbohidrate dan protein

3. Memengaruhi aktivitas jaringan limfoid.

Hipofungsi menyebabkan penyakit Addison sedangkan hiperfungsi menyebabkan kelainan-kelainan yang mirip dengan tumor suprarenalis bagian korteks dengan gejala-gejala pada wanita biasa terjadinya gangguan pertumbuhan seks sekunder

Fungsi kelenjar suprarenalis bagian medulla adalah

1. Vasokontriksi pembuluh darah perifer

2. Relaksasi bronkus

3. Kontraksi selaput lender dan arteriol pada kulit berguna untuk mengurangi perdarahan pada operasi kecil.

\section{System Kekebalan.}

HCG mampu menurunkan respon imun pada perempuan hamil. Selain itu kadar IgG,IgA dnan IgM serum menurun mulai dari minggu ke-10 kehamilan hingga mencapai kadar terendah pada minggu ke-30 dan tetap berada pada kadar ini, hingga aterem.

\section{System Perkemihan}


Ureter membesar, tonus otot-otot saluran kemih menurun akibat pengaruh estrogen dan progesterone. Kencing lebih sering (polyuria), laju filtrasi meningkat hingga 60\%-150\%. Dinding saluran kemih bisa tertekan oleh perbesaran uterus, menyebabkan hidroureter dan mungkin hidronefrosis sementara. Kadar kreatinin,urea dan asam urat dalam darah mungkin menurun namun ini dianggap normal.

\section{Sistem Pencernaan}

Estrogen dan hCG meningkat,dengan efek samping mual dan muntah-muntah. Selain itu, terjadi juga perubahan peristaltik dengan gejala sering kembung, konstpasi, lebih sering lapar/perasaan ingin makan terus (mengidam),juga akibat peningkatan asam lambung. Pada keadaan patologik tertentu, terjadi muntah-muntah banyak sampai lebih dari 10 kali per hari (hyperemesis gravidarum).

Saliva meningkat dan pada trimester pertama ,mengeluh mual dan muntah. Tonus otot-otot saluran pencernaan melemah sehingga motilitas dan makanan akan lebih lama berada dalam saluran makanan. Resorbsi makanan baik, namun akan menimbulkan obstipasi. Gejala muntah (emesis gravidarum sering terjadi biasanya pada pagi hari disebut sakit pagi (morning sickness).

\section{System Musculoskeletas}

Estrogen dan realksasi memberi efek maksimal pada relaksasi otot dan ligament pelvic pada akhir kehamilan. Relaksasi ini digunakan oleh pelvis untuk meningkatkan kemampuannya dalam menguatkan posisi janin diakhir kehamilan dan saat kelahiran. Ligamen pada simipisis pubis dan sakroiliaka akan menghilang karena berelaksasi sebagai efek dari estrogen. Lemahnya dan membesarnya jaringan 
menyebabkan terjadinya hidrasi pada trimester akhir. Simpisis pubis melebar hingga $4 \mathrm{~mm}$ pada usia gestasi 32 minggu dan sakrokoksigeus tidak teraba, diikuti terabanya koksigeus sebagai pengganti bagian belakang.

\section{System Kardiovaskuler}

Meningkatnya beban kerja menyebabkan otot jantung mengalami hipertrofi, terutama ventrikel kiri sebagai pengatur pembesaran jantung. Pembesaran uterus menekan jantung ke atas dan kiri. Pembuluh jantung mengalirkan darah keluar jantung ke bagian atas tubuh, juga menghasilkan elektrokardiografi dan radiografi yang perubahannya sama dengan iskemik pada kelainan jantung. Perlu diperhatikan juga jantung pada perempuan hamil normal. Suara sistolik jantung dan murmur yang berubah adalah normal.

Selama hamil,kecepatan darah meningkat (jumlah darah yang dialirkan oleh jantung dalam setiap denyutnya) sebagai hasil dari peningkatan curah jantung. Ini meningkatkan volume darah dan oksigen keseluruh organ dan jaringan ibu untuk pertumbuhan janin. Denyut jantung meningkat dengan cepat setelah usia kehamilan 4 minggu dari 15 denyut permenit menjadi 70-85 denyut permenit. Aliran darah meningkat dari $64 \mathrm{ml}$ menjadi $71 \mathrm{ml}$. Sementara tekanan sistolik hampir konstan, tekanan diastolic menurun drastic pada trimester I, mencapai yang terendah pada usia kehamilan 16-20 minggu. Pada termin berikutnya, kembali pada tekanan yang sama seperti trimester I. Saat pertengahan semester perubahan dalam tekanan darah menyebabkan kondisi tidak sadar/pingsan pada ibu hamil.dengan berlanjutnya kehamilan, keadaan yang tidak 
mendukung, seperti posisi telentang harus dihindarkan karena bisa menyebabkan hipertensi yang terjadi pada $100 \%$ perempuan hamil dikenal juga dengan sindrom hipotensif telentang .

Pada kehamilan uterus vena kava sehingga mengurangidarah vena yang akan kembali ke jantung. Curah jantung mengalami pengurangan sampai $23-30 \%$ dan tekanan darah bisa turun $10-15 \%$ yang bisa menyebabkan pusing,mual dan muntah. Vena kava menjadi niskin oksigen di akhir kehamilan sejalan dengan meningatnya distensi dan tekanan pada vena kaki, vulva,rectum dan pelvis yang akan menyebabkan edema dibagian kaki, vena dan hemoroid.

\section{System integument}

Pada kulit terjadi perubahan deposit pigmen dan hiperpigmentasi karena pengaruh Melanophore Homron lobus hipofisis anterior dan pengaruh kelenjar suprarenalis. Hiperpigmentasi ini terjadi pada striae gravidarum livide atau alba,areola mamae, papilla mamae, line nigra, chloasma gravidarum. Setelah persalinan, hiperpigmentasi akan menghilang.

\section{Metabolisme}

Dengan terjadinya kehamilan, metabolisme tubuh mengalami perubahan yang mendasar dimana kebutuhan nutrisi menjadi makin tinggi untuk pertumbuhan janin dan persiapan pemberian ASI.

Perubahan metabolisme tersebut adalah :

Metabolisme basal naik sebesar 15\% sampai 20\% dari semula terutama pada trimester ketiga 
Keseimbangan asam basa mengalami penurunan dari $155 \mathrm{mEq}$ per liter menjadi $145 \mathrm{mEq}$ perliter disebabkan adanya hemodilusi darah dan kebutuhan mineral yang dibutuhkan janin.

Kebutuhan protein perempuan hamil semakin tinggi untuk pertumbuhan dan perkembangan janin, perkembangan organ kehamilan, dan persiapan laktasi. Dalam makanan diperlukan protein tinggi sekitar $0.5 \mathrm{gr} / \mathrm{kgBB}$ atau sebutir telur ayam sehari.

Kebutuhan kalori didapatkan dari karbohidrat, lemak dan protein

Kebutuhan zat mineral untuk ibu hamil :

- Kalsium 1,5 gram tiap hari, 30 sampai 40 gram untuk pembentukan tulang janin

- Fosfor rata-rata 8 gram sehari

- Zat besi $800 \mathrm{mg}$ atau 30 sampai $50 \mathrm{mg}$ sehari

- Air, ibu hamil memerlukan air cukup banyak dan kemungkinan terjadi retensi air

Berat badan ibu hamil bertambah

\section{Berat badan dan indeks Masa Tubuh (IMT)}

Penigkatan berat badan ibu selama kehamilan menandakan adanya adaptasi ibu terhadap pertumbuhan janin. Analisis dari berbagai penelitian menunjukkan bahwa berat badan yang bertambah berhubungan dengan perubahan fisiologi yang terjadi pada kehamilan dan lebih dirasakan pada ibu primigravida untuk menambah berat badan pada masa kehamilan.

Perkiraan peningkatan berat badan :

- 4 kg dalam kehamilan 20 minggu

- 8,5 dalam 20 minggu kedua ( $0,4 \mathrm{~kg} /$ minggu dalam trimester akhir) 
- Totalnya sekitar $12,5 \mathrm{~kg}$

Banyak factor yang mempengaruhi peningkatan berat badan adanya edema, proses metabolisme, pola makan,muntah atau diare dan merokok.

Perubahan berat badan ini dapat dirinci sebagai berikut :

- Janin

$3-3,5 \mathrm{~kg}$

- Plasenta

$0,5 \mathrm{~kg}$

- Air ketuban

$1 \mathrm{~kg}$

- Rahim

$1 \mathrm{~kg}$

- Timbunan lemak

$1,5 \mathrm{~kg}$

- Timbunan protein

$2 \mathrm{~kg}$

- Retensi air garam

$1,5 \mathrm{~kg}$

$$
\mathrm{IMT}=\mathrm{BB} / \mathrm{TB}
$$

(BB dalam satuan $\mathrm{kg}$, TB dalam satuan meter)

IMT di klasifikasikan dalam 4 kategori :

- IMT rendah $\quad(<19,8)$

- IMT Normal $\quad(19,8-26)$

- IMT Tinggi ( $\quad(>26-29)$

- IMT obesitas (>29)

Peningkatan BB total selama hamil yang disarankan berdasarkan BMI :

Sebelum hamil :

- IMT Rendah 
- IMT Normal

- IMT Tinggi

- IMT obesitas
$(11,5-16 \mathrm{~kg})$

$(7,0-11,5 \mathrm{~kg})$

$( \pm 6 \mathrm{~kg})$

\section{System Pernapasan}

Pada kehamilan terjadi perubahan system respirasi untuk bisa memenuh kebutuhan O2. Disamping itu terjadi desakan diafragma akibat dorongan rahim yang membesar pada usia kehamilan 32 minggu. Sebagai kompensasi terjadinya desakan rahim dan kebutuhan sampai $25 \%$ dari biasanya.

\section{System persarafan}

Pada ibu hamil akan ditemukan rasa sering kesemutan atau acroestesia pada ekstremitas disebabkan postur tubuh ibu yang membungkung. Oedema pada trimester III edema menekan saraf perifer bawah ligament carpal pergelangan tangan menimbulkan carpal turner sindrom yang ditandai dengan parestisia dan nyeri pada tangan yang menyebar ke siku. Pada bayi, system saraf (otak dan struktur-struktur lain seperti tulang belakang muncul pada minggu ke-4 sewaktu saraf mulai berkembang. Pada minggu ke-6 kehamilan divisi utama dari system saraf pusat mulai terbentuk. Divisi ini terdiri atas otak depan,otak tengah,otak belakang dan saraf tulang belakang. Pada minggu ke-7 otak depan tebagi menjadi dua hemisfer yang akan menjadi dua hemisfer otak disebut hemisfer serebra.

\section{G.PERUBAHAN DAN ADAPTASI PSIKOLOGI DALAM MASA KEHAMILAN}

\section{Perubahan Fisik Ibu}


Masa kehamilan dimulai dari konsepsi sampai lahirnya janin. Lamanya kehamilan yang normal adalah 280 hari atau 40 minggu, dihitung dari hari pertama haid terakhir (syaifuddin, 2001).

Kehamilan 0-8 minggu dengan berat janin 1000 gram, bila berakhir disebut keguguran. Kehamilan 29 sampai 36 minggu,bila terjadi persalinan disebut prematuritas. Kehamilan berumur 37 minggu sampai 42 minggu disebut aterm. Sementara itu kehamilan 42 minggu disebut kehamialn lewat waktu atau serotinus,(Manuaba).

1. Pada kehamilan Trimester I

Tanda fisik pertama yang dapat dilihat pada beberapa ibu adalah perdarahan sedikit atau spoting sekitar 11 hari setelah konsepsi pada saat embrio melekat pada kapisan uterus. Perdarahan Implantasi ini biasanya kurang dari lamanya menstruasi yang normal. Setelah terlambat satu periode mesntruasi, perubahan fisik berikutnya adalah nyeri dan pembesaran payudara, diikuti oleh rasa kelelahan yang kronis/menetap dan sering BAK. Ibu akan mengalami dua gejala yang terakhir selama tiga bulan berikutnya. Morning sicknes atau mual dan muntah biasanya dimuali sekitar 8 minggu dan mungkin berakhir sapai 12 minggu. Pada usia kehamilan 12 minggu pertumbuhan uterus diatas sympisis pubis dapat dirasakan. Ibu biasanya mengalai kenaikan berat badan sekitar 1-2 kg selama trimester pertama.

Adapun perubahan dari bulan ke bulan adalah sebagai berikut :

a. Minggu ke-4/bulan I

Ibu terlambat menstruasi payudara menjadi nyeri dan membesar. Kelelahan yang kronis atau menetap dan sering 
BAK mulai terjadi. Keadaan ini berlangsung selama tiga bulan berikutnya. HCG ada didalam urine dan serum 9 hari setelah konsepsi.

b. Minggu ke-8/bulan 2

Mual dan muntah (morning Sicknes) mungkin terjadi sampai usia kehamilan 12 minggu. Uterus berubah dari bentuk pir menjadi globular. Tanda-tanda Hegar dan Goodell muncul. Serviks fleksi dan leukorea meningkat . penambahan berat badan belum terlihat nyata.

c. Minggu ke-12/bulan ke-3

Tanda Cadwick muncul dan uterus naik diatas simpisis. Kontraksi Brakton Hicks mulai dan mungkin terus berlangsung selama kehamilan. Kenaikan berat badan sekitar 1-2 kg selama trimester pertama. Plasenta sekarang berfungsi penuh dan memproduksi hormon

\section{Trimester II}

Uterus akan terus tumbuh. Pada usia kehamilan 16 minggu,uterus biasanya berada pada pertengahan antara simpisis pubis dan pusat. Penambahan berat badan sekitar 0,4-0,5 kg. ibu mungkin akan merasa banyak energy. Pada usia kehamilan 20 minggu fundus berada dekat dengan pusat. Payudara mulai mengeluarkan kolostrum. Ibu dapat merasakan gerakan bayinya dan juga mengalami perubahan yang normal pada kulitnya meliputi adanya cloasma,linea nigra dan striae gravidarum.

Adapun perubahan dari bulan ke bulan adalah sebagai berikut :

1. Minggu ke-16/bulan ke-4 
Fundus berada ditengah antara simpisis dan pusat. Berat badan ibu bertambah 0,4-0,5 kg/mg selama sisa kehamilan dan mungkin mempunyai energy. Sekresi vagina meningkat (tetapi normal jika tidak gatal,iritasi atau berau busuk). Tekanan pada kandung kemih berkurang sehingga frekuensi sering BAK berkurang.

2. Minggu ke-20/bulan ke-5

Fundus mencapai pusat. Payudara memulai sekresi kolostrum. Kantong ketuban menampung $400 \mathrm{ml}$ cairan. Rasa akan pingsan dan pusing mungkin terjadi terutama jika posisi berubah secara mendadak. Varises pembuluh darah mungkin terjadi. Ibu merasakan getaran janin. Areola bertambah gelap. Hidung tersumbat mungkin terjadi kram pada kaki mungkin ada dan kosntipasi mungkin dialami.

3. Minggu ke-24/bulan ke-6

Fundus diatas pusat. Sakit punggung dan kram pada kaki mungkin terjadi. Perubahan kulit bisa berupa striae gravidarum,chloasma,line nigra, dan jerawat. Mimisan dapat terjadi dan mungkin mengalami gata-gatal pada abdomen karena uterus membesar dan kulit meregang.

3. Trimester III

Pada usia kehamilan 25 minggu,fundus berada pada pertengaha antara pusat dan sifoideus. Pada usia kehamilan 32-36 minggu,fundus mencapai prosesus sifoideus. Payudara penuh dan nyeri tekan. Sering BAK kembali terjadi. Sekitar usia 38 minggu bayi masuk/turun ke dalam panggu. Sakit punggung dan sering 
BAK meningkat. Ibu mungkin menjdai sulit tidur. Kontraksi Brakton Hicks meningkat.

Adapun perubahan dari bulan ke bulan adalah sebagai beriktu:

\section{Minggu ke-28/bulan ke-7}

Fundus berada dipertengahan antara pusat dan sifoideus. Hemoroid mungkin terjadi. Pernapasan dada menggantikan pernapasan perut. Garis bentuk janin dapat dipalpasi. Rasa panas dalam perut mungkin mulai terasa.

2. Minggu ke-32/bulan ke-8

Fundus mencapai prosesus xifoideus,payudara penuh dan nyeri tekan. Sering BAK mungkin kembali terjadi. Selain itu, mungkin juga mengalami dyspnea.

3. Minggu ke-38/bulan ke-9

Penurunan bayi ke dalam pelvis/panggul ibu (lightening). Plasenta setebal hamper 4 kali waktu usia kehamilan 18 minggu dan beratnya 0,5-0,6 kg. Sakit punggung dan sering BAK meningkat. Braxton Hicks meningkat karena serviks dan segmen bawah Rahim disiapkan untuk persalinan

\section{Perubahan Psikologis Pada Ibu Hamil}

Selama hamil kebanyakan wanita mengalami perubahan psikologis dan emosional. Sering kali kita mendengar seorang wanita mengatakan betapa bahagianya karena menjadi seorang ibu dan telah memilihkan sebuah nama untuk bayi yang akan dilahirkannya. Namun tidak jarang ada wanita yang merasa khawatir kalau terjadi masalah dalam kehamilannya,khawatir kalau ada kemumgkinan dia kehilangan kecantikannya dan kemungkinan bayinya tidak normal. 
Sebagai seorang bidan anda harus menyadari adanya perubahanperubahan tersebut pada wanita hamil agar dapat memberikan dukungan dan memperhatikan keprihatinan,kehamilan,ketakutan dan pertanyaannya.

\section{Perubahan Psikologis pada Trimester I (1-3 bulan).}

Segera setelah konsepsi, kadar hormon progesterone dan estrogen dalam tubuh akan meningkat. Hal ini akan menyebabkan timbulnya mual muntah pada pagi hari,lemah,lelahdan membesarnya payudara. Ibu merasa tidak sehat dan sering kali membenci kehamilannya. Banyak ibu yang merasakan kekecewaan, penolakan, kecemasan dan kesedihan. Seringkali pada awal masa kehamilan ibu berharap untuk tidak hamil. Pada trimester pertama,seorang ibu akan selalu mencari tanda-tanda untuk lebih meyakinkan bahwa dirinya memang hamil. Setiap perubahan yang terjadi pada tubuh akan selalu diperhatikan secara seksama. Karean perutnya masih kecil, kehamilan merupakan rahasia seorang ibu yang mungkin diberitahukan atau dirahasiakannnya.

Hasrat untuk melakukan hubungan seksual pada perempuan di trimester pertama ini berbeda-beda. Walau beberapa perempuan mengalami gairah seks yang lebih tinggi, kebanyakan mengalami penurunan libido selama periode ini. Keadaan ini menciptakan adanya kebutuhan untuk berkomunikasi secara terbuka dan jujur dengan suami. Banyak perempuan merasa butuh untuk dicintai dan merasakan keinginan kuat untuk mencitai, namun tanpa 
berhubungan seks. Libido sangat dipengaruhi oleh kelelahan, rasa mual, pembesaran payudara, keprihatinan dan kekhawatiran.

Reaksi pertama seorang laki-laki ketika mengetahui bahwa dirinya akan menjadi ayah adalah timbulnya kebanggaan atas kemampuannya untuk mempunyai keturunan bercampur dengan keprihatinan akan kesiapannya menjadi seorang ayah dan pencari nafkah bagi keadaan ibu yang sedang mulai hamil dan menghindari berhubngan seks karena takut mencederai bayinya.

\section{Perubahan Psikologis pada Trimester II (4-6 bulan).}

Pada trimester ini biasanya ibu sudah merasa sehat. Tubuh ibu telah terbiasa dengan kadar hormon yang lebih tinggi dan rasa tidak nyaman karena hamil sudah berkurang. Ibu telah menerima kehamilannya dan mulai dapat menggunakan energy serta pikirannya secara lebih konstruktif. Pada trimester ini pula ibu mampu merasakan gerakan rasa tidak nyaman seperti yang dirasakannya pada trimester pertama dan merasakan naiknya libido

\section{Perubahan Psikologis Pada Trimester III (7-9 bulan)}

Trimester ketiga seringkali disebut periode menunggu dan waspada sebab pada saat itu ibu merasa tidak sabar menunggu kelahiran bayainya. Ibu sering merasa khawatir bila bayinya lahir sewaktuwaktu. Ibu sering ,erasa khawatir kalua-kalu bayinya lahir tidak normal. Kebanyakan ibu juga akan bersikap melindungi bayinya dan cenderung menghindari orang atau benda apa saja yang dianggapnya membahayakan bayi.

Rasa tida nyaman akibat kehamilan timbul kembali pada trimester ketiga dan banyak ibu merasa aneh atau jelek. Disamping 
itu ibu mulai merasa sedih karena akan berpisah dari bayinya dan kehilangan perhatian khusus yang diterima semasa hamil.

Trimester ketiga adalah saat persiapan aktif untuk kelahiran bagi bayi dan kebahagiaan dalam menanti seperti apa rupa bayi nantinya. 


\section{BAB III \\ MENDIAGNOSA KEHAMILAN}

\section{A. Pendahuluan}

1. Deskripsi Singkat

Dengan terjadinya kehamilan maka seluruh sistem genitalia wanita berubah. Untuk dapat menegakkan diagnosa kehamilan ditetapkan dengan melakukan penilaian terhadap tanda dan gejala kehamilan. Berikut akan dibahas mengenai tanda-tanda mungkin hamil, tanda pasti hamil dan tanda tidak pasti hamil sehingga dapat mendiagnosis kehamilan.

2. Tujuan Instruksional Khusus (TUK)

Setelah mengikuti mata kuliah ini mahasiswa diharapkan mampu memahami dan menjelaskan tentang tanda-tanda kehamilan dan pemeriksaan diagnostik kehamilan dengan benar.

\section{B. Tanda Dan Gejala Kehamilan}

Seorang perempuan bisa saja memiliki semua tanda dan gejala kehamilan tetapi tidak hamil. Atau hanya mempunyai beberapa tanda dan gejala tetpai jelas hamil. Berbagai tanda dan gejala kehamilan hanyalah merupakan petunjuk. Penting untuk memperhatikannya namun kita tidak bisa mengandalkannya guna mendapatkan kepastian.

Lama kehamilan berlangsung sampai persalinan aterm sekitar 280 sampai 300 hari dengan perhitungan sebagai berikut :

1. Kehamilan sampai 28 minggu dengan berat janin 1000 gram bila berkahir disebut dengan keguguran

2. Kehamilan 29 sampai 36 minggu bila terjadi persalinan disebut prematuritas 
3. Kehamilan berumur 37 tahun sampai 42 minggu disebut aterm

4. Kehamilan melebihi 42 minggu disebut kehamilan lewat waktu atau serotinus

Kehamilan dibagi menjadi 3 trimester yaitu ;

1. Trimester pertama 0-12 minggu

2. Terimester kedua 13-28 minggu

3. Trimester ketiga 29 sampai 42 minggu.

Untuk memastikan kehamilan ditetapkan dengan melakukan penilaian terhadap beberapa tanda dan gejala hamil .

\section{Tanda Pasti Kehamilan}

Tanda pasti adalah tanda yang menunjukkan langsung keberadaan janin yang dapat dilihat langsung oleh pemeriksa.

Tanda Pasti Kehamilan yaitu :

a. Gerakan janin yang dapat dilihat/dirasa/diraba, juga bagianbagian janin

Gerakan janin ini harus dapat diraba dengan jelas oleh pemeriksa.

Gerakan janin baru dapat dirasakan pada usia kehamilan sekitar 20 minggu.

b. Denyut jantung janin ketika usia kehamilan 10-20 minggu

1) Didengar dengan stetoskop monoral Leanek

2) Dicatat dsn didengar dengan alat Doppler

3) Dicatat dengan feto Elektrokardiogram

4) Dilihat pada ultarosografi (USG).

Dapat didengar pada usia kehamilan 12 minggu dengan menggunakan alat fetal electrokardiograf (Doppler). Dengan 
stethoscope laenec, DJJ baru dapat didengar pada usia kehamilan 18-20 minggu.

c. Bagian-bagian janin

Bagian-bagian janin yaitu bagian besar janin (kepala dan bokong) serta bagian kecil janin (lengan dan kaki) dapat diraba dengan jelas pada usia kehamilan lebih tua (trimester terakhir). Bagian janin ini dapat dilihat lebih sempurna menggunakan USG.

d. Terlihat tulang-tulang janin dalam foto Rontgen.

\section{Tanda-tanda tidak pasti hamil}

a. Amenorea

Wanita harus mengetahui tanggal hari pertama haid terakhir (HPHT) supaya dapat ditaksir umur kehamilan dan taksiran tanggal persalinan (TTP) yang dihitung dengan menggunakan rumus dari Naegele yaitu TTP (Hari Pertama HT+7) dan (bulan $\mathrm{HT}+3)$.

b. Mual dan muntah (Nausea dan Vomiting)

Biasanya terjadi pada bulna-bulan pertama kehamilan hingga akhir triwulan pertama. Oleh karena sering terjadi pada pagi hari maka disebut morning sickness. Bila mual dan muntah terlalu sering disebut hyperemesis.

c. Mengidam (ingin makanan khusus)

Ibu hamil sering meminta makanan/minuman tertentu terutama pada bulan-bulan triwulan pertama,tidak tahan suatu bau-bauan.

d. Pingsan

Bila berada pada tempat-tempat ramai sesak dan padat bisa pingsan 
e. Anoreksia (tidak ada selera makan )

Hanya berlangsung pada triwulan pertama kehamilan kemudian nafsu makan timbul kembali.

f. Lelah (fatigue)

Sering terjadi pada trimester pertama, akibat dari penurunan kecepatan basal metabolism (basal metabolism rate-BMR) pada kehamilan yang akan meningkat seiring pertambahan usia kehamilan akibat aktivitas metabolism hasil konsepsi.

g.Payudara

Payudara membesar, tegang,dan sedikit nyeri disebabkan pengaruh estrogen dan progesterone yang merangsang duktus dan alveoli payudara kelenjar Montgomery terlihat lebih membesar

h. Miksi

Miksi/BAK sering terjadi karena kandung kemih tertekan oleh Rahim yang membesar. Gejala ini akan hilang pada triwulan kedua kehamilan. Pada akhir kehamilan,gejala ini kembali karena kandung kemih ditekan oleh kepala janin.

i. Konstipasi/obstipasi

Kosntipasi terjadi karena tonus otot-otot usus menurun oleh pengaruh hormon steroid.

j. Pigmentasi kulit

Pigmentasi kulit oleh pengaruh hormon kortikosteroid placenta, dijumpai di muka (cholasma Gravidarum ), areola payudara,leher dan dinding perut. (line nigra $=$ grisea).

k. Epulis atau dapat disebut juga hipertrofi dari papil gusi,sering terjadi pada triwulan pertama. 
1. Pemekaran vena-vena (varises dapat terjadi pada kaki, betis,dan vulva. Keadaan ini biasanya dijumpai pada triwulan akhir.

\section{Tanda-Tanda Kemungkinan Hamil}
a. Perut membesar
b.Uterus membesar, terjadi perubahan dalam bentuk besar dan konsistensi dari tahim.
c. Tanda Hegar

Ditemukan pada kehamilan 6-12 minggu yaitu adanya uterus segmen bawah Rahim yang lebih lunak dari bagian yang lain.

d. Tanda Chadwick

Adanya perubahan warna pada serviks dan vagina menjadi kebirubiruan.

e. Tanda Piscaseck

Yaitu adanya tempat yang kosong rongga uterus karena embrio biasanya terletak disebelah atas, dengan bimanual akan terasa benjolan yang asimetris.

f. Kontraksi-kontraksi kecil pada uterus bila dirangsang (Braxton hicks).

Merupakan peregangan sel-sel otot uterus,akibat meningkatnya actomysin didalam otot uterus. Kontraksi ini tidak bermitrik,sporadic, tidak nyeri, biasanya timbul pada kehamilan delapan minggu, tetapi baru dapat diamatai dari pemeriksaan abdominal pada trimester ketiga. Kontraksi ini akan terus meningkat frekuensinya, lamanya dan kekuatannya sampai mendekati persalinan. 


\section{g. Teraba Ballotement}

Ketukan yang mendadak pada uterus menyebabkan janin bergerak dalam cairan ketuban yang dapat dirasakan oleh tangan pemeriksa. Hal ini harus ada pada pemeriksaan kehamilan karena perabaan bagian seperti bentuk janin saja tidak cukup karena dapat saja merupakan myoma uteri.

h. Reaksi kehamilan posistif.

Pemeriksaan ini adalah untuk mendeteksi adanya Human Chorionik Gonadotropin (hCG) yang di produksi oleh sinsiotropoblastik sel selama kehamilan. Hormon direkresi pada urine ibu. Hormon ini dapat mulai dideteksi pada 26 hari setelah konsepsi dan meningkat dengan cepat pada hari ke 30-60. Tingkat tertinggi pada hari 60-70 usia gestasi, kemudian menurun pada hari ke 100-130.

\section{ASUHAN ANTENATAL CARE}

1. Pengertian Asuhan Antenatal care

Antenatal care adalah suatu program yang terencana berupa observasi, edukasi dan penanganan medic pada ibu hamil,untuk memperoleh suatu proses kehamilan dan persiapan persalinan yang aman dan memuaskan (Musdalifah,2009).

2. Jadwal Pemeriksaan Kehamilan Adapun jadwal pemeriksaan antenatal adalah :

a. Pemeriksaan awal dilakukan setelah diketahui terlambat haid

b. Pemeriksaan ulang

- Setiap bulan sampai umur kehamilan 6-7 bulan

- Setiap 2 minggu sampai kehamilan berumur 8 bulan 
- Setiap 1 minggu sejak umur kehamilan 8 bulan sampai terjadi persalinan

c. Menurut (Mufdillah,2009), frekuensi pelayanan antenatal oleh WHO ditetapkan 4 kali kunjungan ibu hamil dalam pelayanan antenatal selama kehamilan dengan ketentuan 1 kali pada trimester pertama $(\mathrm{K} 1)$ dan 1 kali pada trimester dua dan dua kali pada trimester ketiga (K4).

3. Pelayanan Asuhan Antenatal

Pelayanan ANC minimal 5T,meningkat menjadi 7T dan sekarang menjadi $12 \mathrm{~T}$, sedangkan untuk daerah gondok dan endemic malaria menjadi 14T yaitu sebagai berikut:

d. Timbang Berat Badan dan Tinggi badan

Tinggi badan ibu dikategorikan adanya resiko apabila hasil pengukuran $<145 \mathrm{~cm}$. Berat badan ditimbang setiap ibu datang atau berkunjung untuk mengetahui kenaikan BB dan penurunan BB. Kenaikan BB ibu hamil normal rata-rata antara $6,5 \mathrm{~kg}-16$ $\mathrm{kg}$ (Sayono,2010).

e. Tekanan darah

Diukur setiap kali ibu datang atau berkunjung. Deteksi tekanan darah yang cenderung naik diwasapadai adanya gejala hipertensi dan preeklamsia. Apabila turun dibawah normal kita pikirkan kearah anemia. Tekanan darah normal berkisar 110/80 -120/80 $\mathrm{mmHg}$.

f. Pengukuran tinggi fundus Uteri 
Menggunakan pita sentimeter,letakkan titik nol pada tepi atas sympisis dan rentangkan sampai fundus uteri (tidak boleh ditekan)

g. Pemberian imunisasi TT

Untuk melindungi dari tetanus neonatorum. Efek samping TT yaitu Nyeri,Kemerah-merahan dan bengkak 1-2 hari pada tempat penyuntikan

h. Pemberian tablet Fe (Tablet Tambah darah)

Untuk memenuhi kebutuhan volume darah pada ibu hamil dan nifas karena masa kehamilan kebutuhan meningkat seiring dengan pertumbuhan janin.

i. Pemeriksaan $\mathrm{Hb}$

Pemeriksaan $\mathrm{Hb}$ dilakukan pada kunjungan ibu hamil yang pertama kali kemudian diperiksa menjelang persalinan. Pemeriksaan HB adalah salah satu upaya untuk mendeteksi anemia pada ibu hamil.

j. Pengambilan darah

Pemeriksaan Veneral Desease research Laboratory (VDRL) untuk mengetahui adanya treponema pallidum/penyakit menular seksual antara lain syphilis.

k. Pemeriksaan urine reduksi

Dilakukan pemeriksaan urine reduksi hanya kepada ibu dengan indikasi penyakit gula/DM atau riwayat penyakit gula keluarga ibu dan suami.

1. Perawatan payudara 
Meliputi senam payudara, perawatan payudara,pijat tekan payudara yang ditunjukkan kepada ibu hamil. Perawatan payudara dilakaukan 2 kali sehari sebelum mandi dan mulai pada kehamilan 6 bulan.

m. Senam ibu hamil

Bermanfaat membantu ibu dalam persalinan dan mempercepat pemulihan setelah melahirkan serta mencegah sembelit

n. Pemberian obat malaria

Pemberian obat malaria diberikan khusus untuk pada ibu hamil di daerah endemic malaria atau kepada ibu dengan gejala khas malaria yaitu panas tinggi disertai menggigil.

o. Pemberian kapsul minya beryodium

Kekurangan yodium dipengaruhi oleh faktor-faktor lingkungan dimana tanah dan air tidak mengandung unsur yodium. Akibat kekurangan yodium dapat megakibatkan gondok dan kretin ditandai dengan gangguan fungsi mental, gangguan fungsi pendengaran, gangguan pertumbuhan dan gangguan kadar hormon rendah

p. Temu wicara

Konseling adalah suatu bentuk wawancara atau tatap muka untuk menolong orng lain memperoleh pengertian yang lebih baik mengenai dirinya dalam usahanya untuk memahami dan mengatasi permasalahn yang sedang dihadapinya.

Adapun prinsip dari konseling adalah :

- Keterbukaan

- Empati 
- Dukungan

- Sikap dan respon positif

- Sama derajat

Tujuan konseling pada ANC adalah

- Membantu ibu hamil memahami kehamilannya dan sebagai upaya preventif terhadap hal-hal yang tidak diinginkan.

- Membantu ibu hamil untuk menemukan kebutuhan asuhan kehamilan,penolong persalinan yang bersih dan aman atau tindakan klinik yang mungkin diperlukan (Saryono,2010).

\section{MENENTUKKAN USIA KEHAMILAN}

Menentukan usia kehamilan sangat penting guna memperkirakan persalinan. Usia kehamilan dapat ditentukan dengan :

1. Mempergunakan rumus Neagle

Rumus Neagle memperhitungkan usia kehamilan berlangsung selama 288 hari. Perhitungan kasarnya dapat dipakai dengan menentukan sejak hari pertama menstruasi/Haid terakhir sampai sekarang dan ditambah 288 hari, sehingga perkiraan biasa ditetapkan. Rumus Neagle : +7 hari,- 3 bulan, +1 tahun.

Contoh, HPHT/HPMT tanggal 17 Januari 2019 maka penghitungan perkiraan kelahiran adalah $17+7=24,1+9=10$ sehingga perkiraan persalinan adalah 24 Oktober 2019.

HPHT tanggal 17 Desember 2018 maka perhitungan perkiraan kelahirannya adalah 17+7,12-3,2018+1 = 24 September 2019 . 
2. Gerakan pertama fetus

Dengan memperkirakan terjadinya gerakan pertama kali fetus pada usia kehamilan 16 minggu, perkiraan usia kehamilan bisa ditetapkan. Namun perkiraan kadang kurang tepat

3. Perkiraan tingginya fundus uteri Mempergunakan tinggi fundus uteri untuk memperkirakan usia kehamilan terutama tepat pada kehamilan yang pertama. Pada kehamilan kedua dan seterusnya perkiraan ini kurang tepat.

4. Penentuan usia kehamilan dengan Ultrasonografi (USG)

Bila ragu-ragu ibu bias berkonsultasi untuk menetapkan persalinan. Menentukkan usia kehamilan melalui ultrasonografi dengan cara mengukur bagian janin yaitu :

a. Menentukkan diameter kantong gestasi

b. Menentukan jarak kepala sampai bokong

c. Menentukan jarak tulang biparietal

d. Menentukkan lingkaran perut

e. Menentukan panjang tulang femur

Rumus tidak dapat digunakan jika :

1. Ibu dengan riwayat menstruasi tidak teratur

2. Ibu hamil saat menyusui dan belum menstruasi

3. Ibu hamil post-pil KB belum mesntruasi lagi.

\section{E. DIAGNOSISI BANDING KEHAMILAN}

Pembesaran perut perempuan tidak selamanya menunjukkan adanya kehamilan sehingga perlu dilakukan diagnosis banding diantaranya adalah : 
1. Hamil palsu (pseudocyesis) atau kehamilan spuria Dijumpai tanda dugaan hamil tetapi dengan pemeriksaan alat canggih dan tes biologis tidak menunjukkan kehamilan

2. Tumor kandungan atau myoma uteri

a. Terdapat pembesaran Rahim tetapi tidak disertai tanda hamil

b. Bentuk pembesaran tidak merata

c. Perdarahan banyak saat menstruasi

3. Hematometra
a. Terlambat datang bulan yang dapat melampui usia hamil
b. Perut terasa sakit setiap bulan
c. Terjadi tumpukan darah dalam Rahim
d. Tanda dan pemeriksaan hamil tidak menunjukkan hasil yang positif.
e. Sebab hymen inperforata

4. Kista ovarium
a. Pembesaran perut tetapi tidak disertai tanda hamil
b. Datang bulan terus berlangsung
c. Lamanya pembesaran perut dapat melampaui usia kehamilan
d. Pemeriksaan tes biologis kehamilan degan hasil negatif

5. Kandung kemih yang penuh

Dengan melakukan kateterisasi, pembesaran perut akan menghilang. 


\section{BAB IV}

\section{FAKTOR-FAKTOR YANG MEMPENGARUHI KEHAMILAN}

\section{A. Pendahuluan}

1. Deskripsi Singkat

Dalam mata kuliah ini menjelaskan tentang faktor-faktor yang mempengaruhi kehamilan meliputi faktor fisik, faktor psikologi dan faktor lingkungan serta faktor sosial budaya dan ekonomi

2. Tujuan Instruksional Khusus (TUK)

Setelah mengikuti mata kuliah ini mahasiswa diharapkan memahami dan menjelaskan tentang faktor-faktor yang mempengaruhi kehamilan dengan benar.

\section{B. Faktor Fisik yang Mempengaruhi Kehamilan}

1. Status Kesehatan

\section{a. Kehamilan pada usia tua}

1) Segi negative pada usia tua

a) Kondisi fisik ibu hamil denga usia lebih dari 35 tahun akan sangat menentukan proses kelahirannya. Hal ini mempengaruhi kondisi janin

b) Pada proses pembuahan kualitas sel telur perempuan pada usia ini telah menurun jika dibandingkan dengan sel telur pada perempuan dengan usia reproduksi sehat (25-30 tahun)

c) Kontraksi uterus juga sangat dipengaruhi oleh kondisi fisik ibu. Jika ibu mengalami penurunan kondisi terlebih pada primitua (hamil pertama dengan usia lebih dari 40 tahun), keadaan ini harus benar-benar diwaspadai 
2) Segi positif hamil di usia tua

a) Kepuasaan peran sebagai ibu

b) Merasa lebih siap

c) Pengetahuan mengenai perawatan kehamilan dan bayi lebih baik

d) Mampu mengambil keputusan

e) Karir baik,status ekonomi baik

f) Periode menyusui lebih lama

\section{b.Kehamilan ganda}

1. Pada kasus kehamilan multiple biasanya kondisi ibu lemah. Ini disebabkan oleh adanya beban ganda yang harus ditanggung baik dari pemenuhan nutrisi, oksigen, jika dilihat dari segi biaya, proses persalinan pada kehamilan ganda akan lebih tinggi bila dibandingkan dengan kehamilan tunggal, mengingat adanya kemungkinan terjadinya persalinan secara SC. Selain itu resiko adanya kematian dan cacat juga harus dipertimbangkan.

2. Ketika bayi sudah lahir kemungkinan dalam merawat bayi akan terjadi, karena ibu harus berkonsentrasi lebih tinggi dari pada bayi tunggal.

\section{c. Kehamilan dengan HIV}

Pada kehamilan dengan ibu yang mengidap HIV, janin menjadi sangat rentan terhadap penularan selama proses kehamilan. Virus HIV kemungkinan besar akan ditransfer melalui plasenta ke dalam tubuh bayi. Selain itu adanya pengaruh fisik 
terhadap ibu dan bayi,hal lain yang tidak kalah pentingnya dan harus dipertimbangkan oleh tenaga kesehatan dalam memberikan asuhan adalah kondisi psikologis ibu. Ibu hamil dengan HIV akan mengalami kehilangan, cemas dan depresi, dilema serta khawatir dengan kesehatan bayinya.

Ada dua klasifikasi dasar yang berkaitan dengan status kesehatan atau penyakit yang dialami oleh ibu hamil :

1. Penyakit atau komplikasi akibat langsung kehamilan . termasuk didalamnya adalah :

a) Hyperemesis graviiarum

b) Pre eklmasi/eklamsi

c) Kehamilan ektopik

d) Kelainan plasenta

e) Perdarahan antepartum (perdarahan jalan lahir setelah kehamilan 22 minggu (plasenta previa dan solusio plasenta) f) Gemeli

2. Penyakit atau kelainan yang tidak langsung berhubungan dengan kehamilan

Terdapat hubungan timbal balik dimana penyakit ini dapat memperberat serta mempengaruhi kehamilan atau penyakit ini dapat di perberat oleh kehamilan. Contoh yang termasuk dalam kategori ini adalah :

a) penyakit atau kelainan alat kandungan : varises vulva,karsinoma serviks,mioma uteri,tumor uteri,proplapsus uteri,kista bartoline,DM.

b) penyakit kardiovaskuler : penyakit jantung,hipertensi, 
c) penyakit darah: anemia dalam kehamilan, leukemia, kelainan pembekeuan darah

d) penyakit saluran nafas

e) penyakit hepar dan pancreas

f) penyakit endokrin

g) penyakit menular.

\section{Status Gizi}

Status gizi merupakan hal yang penting diperhatikan pada masa kehamilan karena factor gizi sangat berpengaruh terhadap status kesehatan ibu selama selama hamil serta guna pertumbuhan dan perkembangan janin. Keterbatasan gizi selama hamil sering berhubungan dengan factor ekonomi, pendidikan, social atau keadaan lain yang meningkatkan kebutuhan gizi ibu hamil dengan penyakit infeksi tertentu termasuk pula persiapan fisik untuk persalinan.

a. Kebutuhan Energi

$\checkmark$ TM I : penambahan energy $180 \mathrm{kkal} / \mathrm{hari}$

$\checkmark$ TM II : penambahan $300 \mathrm{kkal} / \mathrm{hari}$

b. Sumber protein

$\checkmark$ Berfungsi membentuk jaringan tubuh yang menyusun struktur organ seperti tulang dan otot

$\checkmark$ Pembentukan sel darah merah dalam tubuh janin

$\checkmark$ Kebutuhan protein bertambah 17 gram lebih banyak

$\checkmark$ Bahan pangan sumber protein yang dikonsumsi sebaiknya 2/3 berupa bahan pangan tinggi kandungan. 
c. Sumber lemak

$\checkmark$ Merupakan sumber energy yang vital untuk pertumbuhan jaringan plasenta dan janin

$\checkmark$ Lemak disimpan sebagai cadangan tenaga : persalinan dan postpartum

$\checkmark$ Membantu proses pembentuka ASI

$\checkmark$ Asam lemak tak jenuh : omega 3 dan omega 6 penting untuk proses tumbuh kembang sel saraf dan sel otak janin.

d. Sumber karbohidrat

$\checkmark$ Merupakan sumber tambahan energy yang dibutuhka bagi pertumbuhan dan perkembangan janin selama dalam kandungan

$\checkmark$ TM I untuk pembentukan sel darah merah

$\checkmark$ TM II dan III untuk persiapan tenaga ibu dalam proses persalinan

e. Sumber vitamin

$\checkmark$ Vitamin A

- Berperan dalam pergantian sel baru pada semua jaringan tubuh dan sel saraf, pembentukan tulang gigi, mencegah cacat bawaan, system kekebalan tubuh ibu hamil

- Kira-kira $300 \mathrm{RE} /$ hari dari sebelum hamil

- Vitamin B : B1 (Tiamin), B2(Ribovlafin), B3 (Niasin), B6 (Piridoksin), B9 (asam Folat), B12 (Kobalamin)

$\checkmark$ Vitamin C

- Berfungsi penyerapan Fe : mencegah anemia

- Memperkuat pembuluh darah: mencegah perdarahan 
- Mengurangi sakit saat bekerja, mengaktifkan kerja sel darah putih

- Meningkatkan system kekebalan tubuh, memperbaiki jaringan tubuh yang rusak

- Ibu hamil dianjurkan menambah asupan vitamin C 10 $\mathrm{mg} / \mathrm{hari}$

$\checkmark$ Vitamin D

- Diperlukan untuk penyerapan kalsium

- Vitamin D dapat diperoleh dari pancaran sinar matahari

$\checkmark$ Vitamin E

- Kebutuhan ibu hamil 15 mg (22,5 IU)/hari

- Berfungsi untuk menjaga struktur dan fungsi komponen sel tubuh ibu dan janin, membantu pembentukan sel darah merah sebagai anti oksidan, melindungi sel tubuh dari kerusakan

f. Sumber mineral

$\checkmark$ Kalsium : untuk pembentukan tulang dan gigi. Kebutuhan kalsium ibu hamil adalah sebesar 500 mg sehari

$\checkmark$ Seng

$\checkmark$ Yodium

$\checkmark$ Zat besi : pemberian tablet fe secara rutin untuk membangun cadangan besi, sintesa sel darah merah. Setiap tablet Fe mengandung FeSO4 320 mg (zat besi $30 \mathrm{mg}$ ), minimal 90 tablet selama kehamilan.

$\checkmark$ Serat 
Proporsi kenaikan berat badan selama hamil sebagai berikut :

- Kenaikan berat badan pada TM I lebih kuran 1 kg. Kenaikan berat badan ini hampir seluruhnya merupakan kenaikan berat badan ibu

- Kenikan berat badan pada trimester II adalah $3 \mathrm{~kg}$ atau 0,3 $\mathrm{kg} /$ minggu. Sebesar $60 \%$ kenaikan berat badan karena pertumbuhan jaringan pada ibu.

- Kenaikan berat badan pada TM III adalah $6 \mathrm{~kg}$ atau 0,3-0,5 $\mathrm{kg} /$ minggu. Timbunan lemak pada ibu lebih kurang $3 \mathrm{~kg}$

\section{Gaya hidup}

a. Mitos atau kepercayaan.

Ada beberapa mitos tertentu yang membahayakan kehamilan da nada yang mendukung terhadap pemeliharaan kesehatan selama hamil. Mitos yang mendukung asuhan dapat diperbolehkan sedangkan yang membahayakan dalam asuhan kehamilan dicegah dengan memberikan konseling dan pendidikan kesehatan yang tepat pada ibu hamil.

b. Kebiasaan minum jamu.

Minum jamu merupakan kebiasaan yang berisiko bagi wanita hamil karena efek minum jamu dapat membayakan tumbuh kembang janin seperti menimbulkan kecacatan, abortus, BBLR,partus prematur,kelainan ginjal asfiksia neonatorum.

c. Aktivitas seksual

Berdasarkan konsep evidence based bahwa ibu hamil tidak harus menghentikan aktivitas seksual ataupun secara khusus mengurangi aktivitas seksual, 
4. Substance abuse

Adalah perilaku yang merugikan atau membahayakan bagi ibu hamil termasuk penyalahgunaan atau penggunaan obat atau zat-zat tertentu yang membahayakan ibu hamil.

a. Penggunaan obat-obatan selama hamil

b. Merokok

c. Alcohol dan kafein

d. Sinar rontgen atau radiasi

Pengaruh sinar radiasi terhadap kehamian terutama adalah pada TM I. karena TM I merupakan dasar pembentukan organ termasuk organ vital otak, sumsum tulang belakang,jantung,ginjal dan pernapasan, sehingga paparan sinar X pada umur kehamilan akan menimbulkan risiko kecacatan janin,abortus dan persalinan premature.

5. Hamil diluar nikah/tidak diinginkan

Jika kehamilan tidak diharapkan maka secara otomatis ibu akan sangat membenci kehamilannnya sehingga tidak ada keinginan dari ibu untuk melakukan hal-hal positif. Pada kehamilan diluar nikah bisa dipastikan bahwa pasangan masih belum siap dalam hal ekonomi selain itu kurang siap untuk merawat bayinya juga perlu diwaspadai agar tidak terjadi postpartum blue.

6. Partner abuse

Partner abuse merupakan kekerasan selama kehamilan oleh pasangan. Kekerasan dapat terjadi baik secara fisik, psikis ataupun seksual sehingga dapat terjadi rasa nyeri dan trauma.

\section{Faktor Psikologis}

1. Stressor internal 
Stressor Internal meliputi kecemasan, ketegangan, ketakutan, penyakit, cacat, tidak percaya diri, perubahan penampilan, perubahan peran sebagai orang tua, takut terhadap kehamilan, persalinan dan kehilangan pekerjaan.

Pemicu stressor internal adalah karena factor dari ibu sendiri. Adanya beban psikologis yang ditanggung oleh ibu dapat menyebabkan gangguan perkembangan bayi yang terlihat ketika bayi lahir.

2. Stressor eksternal

Pemicu stressor eksternal berasal dari luar diri ibu seperti status social, mal adaptasi , relationship, kasih saying,support mental, broken home, respon negative dari lingkungan dan masih banyak kasus yang lainnya.

3. Dukungan keluarga

Setiap tahap usia kehamilan ibu akan mengalami banyak perubahan baik yang bersifat fisik maupun psikologis. Ibu harus melakukan adaptasi pada setiap terbesar terjadi karena dalam rangka melakukan adaptasi terhadap kondisi tertentu

4. Kekerasan yang dilakukan oleh pasangan(substance abuse).

Kekerasan yang dialami oleh ibu hamil dimasa kecil akan sangat membekas dan sangat mempengaruhi kepribadiannya. Ini perlu diperhatikan karena pada klien yang mengalami riwayat ini, tenaga kesehatan harus lebih maksimal dalam menempatkan diri sebagai teman atau pendamping yang bisa dijadikan tempat bersandar bagi klien dalam masalah kesehatan. Klien dengan riwayat ini biasanya tumbuh dengan kepribadian yang tertutup. 


\section{Faktor Lingkungan,Sosial Budaya Dan Ekonomi}

1. Kebiasaan,adat istiadat

Ada beberapa kebiasaan adat istiadat yang merugikan kesehatan ibu hamil. Tenaga kesehatan harus mampu menyikapi hal ini secara bijaksana, jangan sampai menyinggung kearifan local yang sudah berlaku di daerah tersebut. Penyampaian mengenai pengaruh adat bisa melalui berbagai cara, misalnya melalui media massa, pendekatan tokoh masyarakat dan penyuluhan yang menggunakan media efektif.namun, tenaga kesehatan juga tidak boleh mengesampingkan adanya kebiasaan yang sebenarnya mengutungkan bagi kesehatan, tidak ada salahnya memberikan respon yang positif dalam rangka menjalin hubungan yang sinergis dengan masyarakat.

2. Fasilitas kesehatan

Adanya fasilitas kesehatan yang memadai akan sangat menentukan kualitas pelayanan kepada ibu hamil. Deteksi dini terhadap kemungkinan adanya penyulit akan lebih cepat, sehingga langkah antisipasi bisa lebih cepat diambil. Fasilitas kesehatan sangat menentukan atau berpengaruh terhadap upaya penurunan angka kematian ibu. (AKI)

3. Ekonomi

Tingkat social ekonomi terbukti sangat berpengaruh terhadap kondisi kesehatan fisik dan psikologis ibu hamil. Pada ibu hamil dengan tingkat social ekonomi yang baik, otomatis akan mendapatkan kesejahteraan fisik dan psikologis yang baik pula. Status gizi juga akan meningkat karena nutrisi yang didapatkan 
berkualitas. Selain itu,ibu akan terbebani secara psikologis mengenai biaya persalinan dan pemenuhan kebutuhan sehari-hari setelah bayinya lahir. Ibu akan lebih focus untuk mempersiapkan fisik dan mentalnya sebagai seorang ibu. Sementara pada ibu hamil dengan kondisi ekonomi yang lemah, akan mendapatkan banyak kesulitan terutama mengenai pemenuhan kebutuhan primer. 


\section{BAB V \\ KEBUTUHAN DASAR IBU HAMIL \\ SESUAI DENGAN TAHAP PERKEMBANGANNYA}

\section{A. Pendahuluan}

1. Deskripsi Singkat

Pokok bahasan ini akan membahas kebutuhan dasar ibu hamil yang meliputi oksigen, nutrisi, personal hygiene, pakaian, eliminasi, seksual, mobilisasi, body mekanik, senam hamil, istirahat-tidur, imunisasi, traveling, persiapan laktasi, persiapan persalinan dan kelahiran bayi, memantau kesejahteraan janin, ketidaknymanan dan cara mengatasi, pekerjaan dan tanda bahaya kehamilan.

2. Tujuan Instruksional Khusus (TUK)

Setelah mengikuti mata kuliah ini mahasiswa diharapkan mampu memahami dan menjelaskan tentang kebutuhan dasar ibu hamil secara rinci. .

\section{B. Kebutuhan Fisik Ibu Hamil Trimester I II dan III}

1. Oksigen

Meningkatnya jumlah progesterone selama kehamilan mempengaruhi pusat pernapasan, $\mathrm{CO} 2$ menurun dan $\mathrm{O} 2$ meningkat. O2 meningkat akan bermanfaat bagi janin. Kehamilan menyebabkan hiperventilasi, dimana keadaan Oksigen menurun. Pada TM III janin membesar dan menekan diafragma, menekan vena cava inferior yang menyebabkan nafas pendek-pendek

2. Nutrisi

a. Kalori 
Jumlah kalori yang diperukan ibu hamil setiap harinya adalah 2500 kalori. Jumlah kalori yang berlebih dapat menyebabkan obesitas dan ini merupakan factor prediposisi atas terjadinya preeklamsia. Total pertambahan berat badan sebaiknya tidak melebihi 10-12 kg selama hamil

b. Protein

Jumlah protein yang diperlukan oleh ibu hamil adalah 85 gram per hari. Sumber protein tersebut bisa diperoleh dari tumbuhtumbuhan (kacang-kacangan) atau hewani (ikan,ayam keju,susu, telur). Defisiensi protein dapat menyebabkan kelahiran premature, anemia dan odema.

c. Kalsium

Kebutuhan kalsium ibu hamil adalah $1,5 \mathrm{~kg}$ per hari. Kalsium dibutuhkan untuk pertumbuhan janin, terutama bagi pengembangan otot dan rangka. Sumber kalsium yang mudah diperoleh adalah susu, keju, yougurt dan kalsium karbonat. Defisiensi kalsium dapat mengakibatkan riketsia pada bayi atau osteomalasia

d. Zat besi

Diperlukan asupan zat besi bagi ibu hamil dengan jumlah $30 \mathrm{mg}$ per hari terutama setelah Trimester kedua. Bila tidak ditemukan anemia pemberian besi /mingu telah cukup. Zat besi yang diberikan bisa berupa ferrous gluconate, ferrous fumarate. Kekurangan zat besi pada ibu hamil dapat menyebabkan anemia defisiensi zat besi. 
e. Asam folat

Jumlah asam folat yang dibutuhkan ibu hamil sebesar 400 mikro gram per hari. Kekurangan asam folat dapat menyebabkan anemia megaloblastik pada ibu hamil.

f. Air

Air diperlukan tetapi sering dilupakan pada saat pengkajian. Air berfungsi untuk membantu system pencernaan makanan dan membantu proses transportasi. Selama hamil terjadi perubahan nutrisi dan cairan pada membrane sel. Air menjaga keseimbangan sel, darah, getah bening dan dan cairan vital tubuh lainnya. Air menjaga keseimbangan suhu tubuh karena itu dianjurkan untuk minum 6-8 gelas. (1500-2000 ml) air, suhu dan jus tiap 24 jam.

Sebaiknya membatasi minuman yang mengandung kafein seperti teh, cokelat,kopi,dan minuman yang mengandung pemanis buatan(sakarin) karena bahan ini mempunyai reaksi silang terhadap plasenta.

Makanan Seimbang Ibu Hamil Dalam Sehari

\begin{tabular}{|l|l|}
\hline Waktu Makan & Menu sedang yang dapat disajikan \\
\hline 07.00 & $\begin{array}{l}\text { Nasi } \\
\text { Sayur Kacang Panjang +daging } \\
\text { Telur ceplok (mata sapi) }\end{array}$ \\
\hline 10.00 & $\begin{array}{l}\text { Bubur kacang hijau } \\
\text { Susu dan pisang goring }\end{array}$ \\
\hline 12.00 & $\begin{array}{l}\text { Nasi } \\
\text { Gado-gado } \\
\text { Ayam goring } \\
\text { Salad buah ,papaya }+ \text { tomat }\end{array}$ \\
\hline 16.00 & Lemper dan air jeruk \\
\hline
\end{tabular}




\begin{tabular}{|l|l|}
\hline & $\begin{array}{l}\text { Nasi } \\
\text { Cah sawi dan daging }\end{array}$ \\
\hline 18.00 & $\begin{array}{l}\text { Ikan bumbu acar } \\
\text { Pisang raja }\end{array}$ \\
\hline 20.00 & Pisang kukus \\
\hline
\end{tabular}

3. Personal hygiene (kebersihan Pribadi)

Kebersihan tubuh harus terjaga selama kehamilan. Perubahan anatomic pada perut, area genitalia/lipat paha, dan payudara menyebabkan lipatan-lipatan kulit menjadi lebih lembabdan mudah terinvestasi oleh mikroogranisme. Sebaiknya gunakan pancuran atau gayung pada saat mandi, tidak dianjurkan berendam dalam bathub dan melakukan vaginal doueche.

Bagian tubuh lain yang sangat membutuhkan perawatan kebersihan adalah daerah vital karena saat hamil biasanya terjadi pengeluaran secret vagina yang berlebih. Selain mandi, mengganti celana dalam secara ruitn minimal sehari dua kali sangat dianjurkan.

4. Pakaian

Hal yang perlu diperhatikan untuk pakaian ibu hamil :

a. Pakaian harus longgar, bersih, dan tidak ada ikatan yang ketat didaerah perut

b. Bahan pakaian usahakan yang mudah menyerap keringat

c. Pakailah bra yang menyokong payudara

d. Memakai sepatu dengan hak rendah

e. Pakaian dalam harus selalu bersih

5. Eliminasi 
Keluhan yang sering muncul pada ibu hamil berkaitan dengan eliminasi adalah konstipasi dan sering BAK. Konstipasi terjadi karena adanya pengaruh hormon progesterone yang mempunyai efek rileks terhadap otot polos, salah satunya otot usus. Selain itu, desakan usus oleh pembesaran janin juga menyebabkan bertambahnya konstipasi. Tindakan pencegahan yang dapat dilakukan adalah dengan mengonsumsi makanan tinggi serat dan banyak minum air putih, terutama ketika lambung dalam keadaan kosong dapat merangsang gerak peristaltic usus. Jka ibu sudah mengalami dorongan, segeralah untuk buang air besar agar tidak terjadi konstipasi.

Sering buang air kecil merupakan keluhan yang umum dirasakan oleh ibu hamil,terutama pada TM I dan III. Hal tersebut adalah kondisi yang fisiologi. Ini terjadi karena pada awal kehamilan terjadi pembesaran uterus yang mendesak kantong kemih sehingga kapasitasya berkurang. Sedangkan pada TM III terjadi pembesaran janin yang juga menyebabkan desakan pada kantong kemih. Tindakan mengurangi asupan cairan untuk mengurangi keluhan ini sangat tidak dianjurkan karena akan menyebabkan dehidrasi.

6. Seksual

Hubungan seksual selama kehamilan tidak dilarang selama tidak ada riwayat penyakit seperti berikut ini :

a. Sering abortus dan kelahiran premature

b. Perdarahan pervaginam

c. Koitus harus dilakukan dengan hati-hati terutama pada minggu pertama kehamilan 
d. Bila ketuban sudah pecah, koitus dilarang karena dapat menyebabkan infeksi janin intra uteri.

7. Mobilisasi, body mekanik.

Perubahan tubuh yang paling jelas adalah tulang punggung bertambah lordosis karena tumpuan tubuh bergeser lebih kebelakang dibandingkan sikap tubuh ketika tidak hamil. Keluhan yang sering muncul dari perubahan ini adalah rasa pegal di punggung dan kram kaki ketika tidur malam. Untuk mencegah dan mengurangi keluhan ini, dibutuhkan sikap tubuh yang baik.

a. Pakailah sepatu dengan hak yang rendah/tanpa hak dan jangan terlalu sempit

b.Posisi tubuh saat mengangkat beban yaitu dalam keadaan tegak lurus dan pastikan beban terfokus pada lengan

c. Tidur dengan posisi kaki ditinggalkan

d. Duduk dengan posisi punggung tegak

e. Hindari duduk atau berdiri terlalu lama (ganti posisi secara bergantian untuk mengurangi ketegangan otot).

8. Exercise/senam hamil

Senam hamil bukan merupakan suatu keharusan. Namun dengan melakkan senam hamil akan banyak memberi manfaat dalam membantu kelancaran proses persalinan antara lain dapat melatih pernapasan, relaksasi, menguatkan, otot-otot panggul dan perut serta melatih cara mengejan yang benar.

Tujuan senam hamil yaitu memberi dorongan serta melatih jasmani dan rohani ibu secara bertahap agar ibu mampu menghadapi 
persalinan dengan tenag sehingga proses persalinan dapat berjalan lancar dan mudah.

Manfaat senam hamil secara terukur yaitu :

a. Memperbaiki sirkulasi darah

b. Mengurangi pembengkakan

c. Memperbaiki keseimbangan otot

d. Mengurangi risiko gangguan gastrointestinal termasuk sembelit

e. Mengurangi kram/kehang kaki

f. Menguatkan otot perut

g. Mempercepat proses penyembuhan setelah melahirkan.

Senam hamil pada kehamilan normal dilakukan atas nasihat dari dokter/bidan, dan dapat dimulai pada kehamilan kurang dari 16-38 minggu. Ibu hamil bisa mengikuti kelas senam hamil yang disediakan difasilitas kesehatan dengan instruktur yang bersertifikat. Pelaksanaan senam sedikitnya seminggu sekali dan menggunakan pakaian yang sesuai dan longgar. Lakukan selalu pemanasan dan pendinginan setiap kali senam. Intensitas senam harus disesuaikan dengan kondisi tubuh. Bila dilantai, gunakan kasur atau matras saat melakukan senam. Jangan mendadak berdiri saat usai senam tetapi lakukan secara perlahan untuk menghindari pusing.

Beberapa gerakan senam hamil yang dianjurkan adalah sebagai berikut :

a. Gerakan pengencengan abdomen dengan teknik tidur telentang atau miring, lutut ditekuk, tangan diperut. Saat mengeluarkan napas tarik otot-otot abdomen hingga paru-paru kempis 
b. Gerakan pemiringan panggul. Tidur telentang, lutut ditekuk. Gulingkan panggul dengan meratakan punggung bawah kelantai sambil meniadakan rongga. Susutkan otot-otot abdomen pada saat mengeluarkan napas dan kencangkan bokong. Tuhan selama tiga hitungan yang panjang kemudian lepaskan.

c. Goyang panggul. Latihan ketiga adalah variasi dari latihan kedua. Posisi merangkak, tarik masuk perut dan bokong, tekan dengan punggung bagian bawah sambil membuat gerakan punggung kucing yang bundar. Jangan biarkan tulang punggung mengendur. Miringkan panggul ke samping bolak balik, ini adalah variasi yang dikenal dengan sebutan mengibasibaskan ekor.

d. Teknik geraka keempat adalah senm Kegel untuk dasar panggul. Lakukan minimal 100 kali sehari. Untuk menghubungkan set otot ini, lakukan gerakan seolah-olah anda sedang buang air kecil kemudian menahannya sekuat mungkin atau mengentikan alirannya ditengah-tengah. Cara lain yang bisa dilakukan yaitu dengan membayangkan bahwa dasar panggul anda adalah sebuah elevator. Secara perlahan anda naik ke lantai dua kemudian ke lantai tiga dan seterusnya lain turun kembali.

e. Gerakan menekuk. Pada latihan selanjutnya ada tiga gerakan yaitu sebagai berikut

- Tidur telentang,lutut dinaikkan 
- Panggul dimiringkan kebelakanh samnil memegang kedua sisinya. Dekatkan dagu ke dada, hembuskan napas, bungkukkan ke depan kira-kira $20 \mathrm{~cm}$ atau $45^{\circ}$. tahan dalam posisi tersebut sambil terus bernapas. Perlahan kembali ke posisi semula.

- Lekukkan kaki secara diagonal, ini merupakan variasi lain. Gerakkan ini dilakukan terutama jika ada pemisahan dari otot-otot rectum. Caranya sama seperti terutama gerakan sebelumnya tetapi pada lekukan kedepan, tegakkan miring dengan lengan terbentang kearah lutut yang berlawanan.

f. Bridging atau mempertemukan (untuk postur,abdomen dan kenyamanan). Latihan ini bertujuan untuk kenyamanan dan postur tubuh dalam keadaan baik. Langkah-langkah dalam melakukan teknik tersebut adalah sebagai berikut :

- Tidur telentang dengan kaki diatas bangku yang rendah, diujung dinding perut atau diatas meja.

- Susutkan dinding perut, secara perlahan naikkan pinggul dari lantai sehingga badan dan kaki berada dalam satu garis lurus. Jangan melengkungkan badan kebelakang dan ingat untuk bernapas.

- Variasi senam yang bisa dilakukan adalah lutut menekuk dan kaki diatas lantai, dengan urutan satu lutut menekuk dan lainnya lurus sejajar dengan paha tidak lebih tinggi, kemudian hembuskan napas saat anda mengangkat kaki.

g. Gerakan kaki menekuk dan meregang. Teknik pada latihan ini adalah kaki dinaikkan atau kaki pada lutut. Tekukkan 
pergelangan, sedapat mungkin naikkan jari kaki, kemudian arahkan kebawah, sambil menekukkan kaki. Kemudian putar pergelangan dengan lingkaran yang besar dan perlahan, mulamula ke satu arah kemudian kea rah yang berlawanan.

h. Gerakan peregangan otot betis. Teknik latihan ini adalah dengan posisi berdiri, sandarkan tubuh kedepan ke arah dinding dengan satu kaki dibelakang,kaki rata dilantai. Secara perlahan bongkokan lutu kedepan, bernapas perlahan saat otot betis meregang.

i. Gerakan bahu memutar dan lengan menentang. Teknik latihan ini dilakukan dengan duduk, angkat tangan, tekuk siku, lalu letakkan tangan dibahu. Angkat lengan dan putarkan lengan dengan lingkaran kedua arah. Kemudian angkat lengkat lurus tinggi diatas kepala dan secara bergantian angkat masingmasing semakin tinggi dan seakin tinggi (seakan memetik) buah apel dari pohon yang tinggi. Latihan ini juga bisa dilakukan sambil berdiri.

\section{Istrahat / tidur}

Dengan adanya perubahan fisik pada ibu hamil, salah satunya beban berat pada perut, terjadi perubahan sikap tubuh. Tidak jarang ibu akan mengalami kelelahan. Oleh karena itu istrahat dan tidur sangat penting bagi ibu hamil.

Ibu hamil dianjurkan untuk merencanakan periode istirahat, terutama saat hamil tua. Posisi berbaring miring dianjurkan untuk meningkatkan perfusi uterin dan oksigenasi fetoplasental. Selama periode istrahat yang singkat, seorang perempuan bisa mengambil 
posisi telentang kaki disandarkan pada tinggi dinding untuk meningkatkan aliran vena dari kaki dan mengurangi edema kaki serta varises vena.

Relaksasi adalah membebaskan pikiran dan beban dari ketegangan yang dengan sengaja diupayakan dan dipraktikan. Kemampuan relaksasi secara disengaja dan sadar dapat dimanfaatkan sebagai pedoman untuk mengurangi ketidaknyamanan yang normal sehubungan dengan kehamilan. Selain itu, relaksasi juga mengurangi stress sehingga persepsi nyeri tidak mengganggu dan ibu masih mampu melahirkan anak.

Untuk memperoleh relaksasi sempurna, ada beberapa syarat yang harus dilakukan selama berada dalam posisi relaksasi, yaitu :

a. Tekuk semua persendian dan pejamkan mata

b. Lemaskan seluruh otot-otot tubuh termasuk otot-otot wajah

c. Lakukan pernapasan secara teratus dan berirama

d. Pusatkan pikiran pada irama pernapasan atau pada hal-hal yang menyenangkan

e. Apabila pada saat itu keadaan menyilaukan atau gaduh tutup mata dengan saputangan dan tutup telinga dengan bantal.

f. Pilih posisi relaksasi yang menurut anda paling menyenangkan.

Waktu terbaik untuk melakukan relaksasi adalah tiap hari setelah makan siang, pada awal istrahat sore serta malam sewaktu tidur. Ada beberapa posisi relaksasi yang dapat dilakukan sewaktu dalam keadaan istrahat atau selama proses persalinan.

a. Posisi relaksasi dengan telentang 
Berbaring telentang, kedua tungkai kaki lurus dan terbuka sedikit, kedua lengan rileks disamping. Dibawah lutut dan kepala diberi lantai. Pejamkan mata, lemaskan seluruh tubuh, tenang dan lakukan pernapasan yang teratur dan berirama.

b. Posisi relaksasi dengan berbaring miring Berbaring miring, kedua lutut dan kedua lengan ditekuk, dibawah kepala diberi bantal agar tidak menggantung. Pejamkan mata tenang dan atur pernapasan dengan teratur dan berirama

c. Posisi relaksasi dalam keadaan berbaring telentang

Kedua lutut ditekuk, berbaring telentang,kedua lutut ditekuk, kedua lengan disamping telinga, tutuplah mata dan tenang. Posisi ini dapat dilakukan selama akhir kala I

d.Posisi relaksasi dengan duduk

Duduk membungkuk, kedua lengan diatas sandaran kursi atau diatas tempat tidur. Jika duduk,menghadaplah ke tempat tidur. Kedua kaki tidak boleh menggantung. Posisi ini dapat dilakukan selama kala I sebelum naik ketempat persalinan.

Hal-hal yang dianjurkan apabila ibu hamil bepergian adalah sebagai berikut :

a. Hindari pergi kesuatu tempat yang ramai, sesak, panas serta berdiri terlalu lama ditempat tersebut karena akan menimbulkan sesak napas sampai akhirnya jatuh pingsan (sincope).

b. Apabila bepergian selama kehamilan, duduk dalam jangka waktu lama harus dihindari karena dapat menyebabkan 
peningkatan risiko bekuan darah vena dalam dan tromboflebitis selama kehamilan.

c. Perempuan hamil boleh mengendarai mobil maksimal 6 jam dalam sehari dan harus berhenti selama 2 jam.

d. Duduk dalam jangka waktu lama di mobil atau pesawat terbang.

e. Sabuk pengaman sebaiknya selalu dipakai, sabuk tersebut diletakkan dibawah perut ketika kehamilan sudah besar.

10. Imunisasi

Imunisasi selama kehamilan sangat penting dilakukan untuk mencegah penyakit yang bisa menyebabkan kematian ibu dan janin. Jenis imunisasi yang diberikan adalah tetanus toxoid (TT) yang dapat mencegah penyakit tetanus. Imunisasi pada ibu hamil harus terlebih dahulu ditentukan status kekebalan/imunisasinya.

Jadwal pemberian imunisasi tetanus toksoid

\begin{tabular}{|l|l|l|}
\hline Imunisasi & \multicolumn{1}{|c|}{ Interval } & Perlindungan \\
\hline TT1 & Selama kunjungan I & - \\
TT II & 4 minggu setelah TT I & 3 tahun \\
TT III & 6 bulan setelah TT II & 5 tahun \\
TT IV & 1 tahun setelah TT III & 10 tahun \\
TT V & 1 tahun setelah TT IV & $\begin{array}{l}25 \text { tahun -seumur } \\
\text { hidup }\end{array}$ \\
\hline
\end{tabular}

11. Traveling (perjalanan)

Perjalanan ini ada beberapa tips untuk ibu hamil yang akan melakukan perjalanan :

a. Selalu berkonsultasi dengan dokter sebelum melakukan perjalanan atau bepergian, terutama jarak jauh atau international

b. Jangan bepergian dengan perut kosong, apalagi jika sedang mengalami morning sicknes (mual-muntah) 
c. Bawalah beberapa cemilan untuk mencegah mual. Anda tidak pernah tahu kapan merasa lapar saat hamil

d. Bawalah segala yang anda butuhkan dalam tas kecil sehingga akan mudah mengambilnya.

e. Bawalah minuman atau jus

f. Jika berencana bepergian dengan pesawat terbang, periksa dahulu beberapa perusahaan penerbangan karena mereka mempunyai peraturan khusus untuk perempuan hamil, terutama bila kehamilan sudah mencapai 7 bulan. Tanyakan apakah mereka memerlukan suart keterangan dokter sebagai ijin bepergian.

\section{Persiapan laktasi}

Payudara perlu dipersiapkan sejak sebelum bayi lahir sehingga dapat segera berfungsi dengan baik pada saat diperlukan. Pengurutan payudara untuk mengeluarkan sekresi dan membuka duktus sinus laktiferus, sebaiknya dilakukan secara hati-hati dan benar karena pengurutan keliru bisa dapat menimbulkan kontraksi pada Rahim sehingga terjadi kondisi seperti pada uji kesejahteraan janin menggunakan uterotonika. Basuhlah lembut setiap hari pada areola dan putting susu akan dapat mengurangi retak dan lecet. Untuk sekresi yang mongering pada putting susu, lakukan pembersihan dengan menggunakan campuran gliserin dan alcohol. Karena payudara menegang, sensitive dan menjadi lebih besar sebaiknya gunakan penopang payudara yang sesuai.

13. Persiapan persalinan dan kelahiran bayi

Persiapan persalinan adalah rencana tidnakan yang dibuat oleh ibu anggota keluarga dan bidan. Rencana ini tidak harus dalam 
bentuk tertulis dan biasanya memang tidak tertulis. Rencana ini lebih hanya sekedar diskusi untuk memastikan bahwa ibu menerima asuhan yang ia perlukan. Dengan adanya rencana persalinan akan mengurangi kebingungan dan menerima asuhan yang sesuai dan tepat waktu

\section{Komponen Penting Rencana Persalinan}

\section{Membuat Rencana Persalinan}

Hal-hal mengenai pembuatan rencana persalinan adalah sebagai berikut :

1. Tempat persalinan

a. Pemilihan tempat persalinan ditentukan oleh nilai risiko kehamilan dan jenis persalinan yang direncanakan. Persalinan berisiko rendah dapat dilakukan di puskesmas, Polindes atau rumah bersalin sedangkan persalinan berisiko tinggi harus dilakukan di rumah sakit yang memiliki fasilitas kamar operasi, transfuse darah dan perawatan bayi risiko tinggi.

b. Diluar negeri (misalnya di Amerika dan Belanda), persalinan dapat dilakukan di rumah karena memiliki kelebihan dibandingkan persalinan di rumah sakit. Suasana rumah membuat ibu lebih nyaman sehingga proses persalinan lebih lancer dan peran serta suami tampak nyata dirasakan. Walaupun demikian persalinan di rumah memerlukan dukungan infrastrusktur yang baik, serta kesiapan tenaga penolong untuk menghadapi segala 
kemungkinan yang terjadi pada saat persalinan maupun pascapersalinan.

2. Memilih tenga kesehatan terlatih

a. Tenaga kesehatan yang di perbolehkan menolong persalinan adalah dokter umum, bidan serta dokter kebidanan dan kandungan. Di Negara kita masih banyak persalinan yang di tolong oleh dukun bersalin baik yang terlatih maupun yang tidak terlatih. Hal ini masih menjadi kendala dan merupakan salah satu sebab tingginya angka kematian bayi.

b. Pemilihan tenaga penolong persalinan ditentukan oleh pasien, nilai risiko kehamilan dan jenis persalinan yang akan direncanakan bagi masing-masing pasien.

c. Pemilihan pasien berdasarkan risiko dimaksudkan agar penanganan kasus lebih terarah dan ditangani oleh tenaga yang kompeten. Pada saat persalinan, penanganan kasus dilakukan lebih cermat lagi dengan memperhatikan karakteristik kasus. Sebaiknya semua kasus dianggap memiliki risiko tinggi karena tidak ada satu cara pun yang dapat meramalkan bahwa persalinan tesebut pasti berjalan normal sehingga setiap penolong persalinan akan selalu berhati-hati dan mempersiapkan segala sesuatunya untuk mengatasi penyulit yang mungkin terjadi.

d. Selain itu, factor ekonomi, agama, social dan budaya kadang-kadang juga mempengaruhi pemilihan tenaga penolong persalinan. 
- Membuat rencana untuk pengambilan keputusan jika terjadi kegawatdaruratan pada saat pengambil keputusan utama tidak ada

- Mempersiapkan system transportasi jika terjadi kegawatdaruratan.

1)Banyak ibu yang meninggal karena mengalami komplikasi yang serius selama kehamilan, persalinan atau pasca persalinan dan tidak mempunyai jangkaun transportai yang dapat memberikan asuhan yang kompeten untuk mengani masalah mereka.

2)Setiap keluarga seharusnya mempunyai suatu rencana transportasi untuk ibu jika ia mengalami komplikasi dan perlu segera di rujuk ke tingkat asuhan yang lebih tinggi.

Rencana persalinan perlu dipersiapkan lebih dini dalam kehamilan dan harus terdiri atas elemen-elemen dibawah ini :

1. Dimana ibu akan bersalin (desa,fasilitas kesehatan,rumah sakit)

2. Bagaimana cara menjangkau tingkat asuhan yang lebih lanjut jika terjadi kegawatdaruratan

3. Ke fasilitas kesehatan mana ibu akan dirujuk

4. Bagaimana cara mendapatkan dana jika terjadi kegawatdaruratan

5. Bagaimana cara mencari donor darah

6. Membuat rencana/pola menabung 
Mempersipkan peralatan yang diperlukan untuk persalinan. Beberapa hal yang dipersiapkan untuk persalinan adalah sebagai berikut :

a. Biaya

Pendanaan yang memadai perlu direncanakan jauh sebelum masa persalinan tiba. Dana bisa didapatkan dengan cara menabung, dapat melalui arisan, tabungan ibu bersalin (tabulin)

b. Penentuan tempat serta penolong persalinan

c. Anggota keluarga yang dijadikan sebagai pengambil keputusan jika terjadi komplikasi yang membutuhkan rujukan

d. Baju ibu dan bayi serta perlengakapan lainnya

e. Surat-surat fasilitas kesehatan (misalnya ASKES, BPJS, KIS, JKN, jaminan kesehatan dari tempat kerja,kartu sehat )

f. Pembagian peran ketika ibu berada di RS (ibu dan mertua, yang menjaga anak lainnya jika bukan persalinan yang pertama)

\section{Memantau kesejateraan janin}

Kesejahteraan janin dalam kandungan perlu dipantau secara terus menerus agar bila ada gangguan akan bisa segera terdeteksi dan ditangani. Salah satu indicator kesejateraan janin yang dapat dipantau sendiri oleh ibu adalah gerakannya dalam 24 jam. Gerakan janin dalam 24 jam minimal sebanyak 10 kali . Kesejahteraan janin dalam kandungan perlu dipantau secara terus menerus agar bila ada gangguan akan bisa segera terdeteksi dan ditangani. Salah satu indicator kesejateraan janin yang dapat dipantau sendiri oleh ibu adalah gerakannya dalam 24 jam. Gerakan janin dalam 24 jam minimal sebanyak 10 kali . Gerakan ini dirasakan dan dihitung oleh 
ibu sendiri yang dikenal dengan menghitung gerakan janin dipantau melalui sebuah metode yang disebut Non-Stres Test (NST), dengan cara elektroda ditempelkan diperut ibu, yang dihubungkan dengan monitor sehingga setiap ada gerakan janin akan muncul suatu grafik yang tergambar jelas di layar monitor.

15. Ketidaknyamanan dan cara mengatasi

Dalam proses kehamilan terjadi perubahan system dalam tubuh ibu, yang semuanya membutuhkan adaptasi,baik fisik maupun psikologis. Dalam proses adaptasi tersebut, tidak jarang ibu merasakan ketidaknyamanan. Meski ini adalah fisiologi normal tetap perlu diberikan pencegahan dan perawatan. Beberapa ketidaknyamanan dan cara mengatasinya adalah sebagai berikut :

\begin{tabular}{|c|c|c|}
\hline No & Ketidaknyamanan & Cara mengatasi \\
\hline 1 & $\begin{array}{l}\text { Sering buang air kecil } \\
\text { Trimester I dan III }\end{array}$ & $\begin{array}{l}\text { a. Penjelasan mengenai sebab } \\
\text { terjadinya } \\
\text { b. Kosongkan saat ada dorongan } \\
\text { untuk kencing } \\
\text { c. Perbanyak minum saat siang hari } \\
\text { d. Jangan kurangi minum untuk } \\
\text { mencegah nokturia kecuali jika } \\
\text { nocturia sangat mengganggu tidur } \\
\text { dimalam hari } \\
\text { e. Batasi minum kopi,the dan soda } \\
\text { f. Jelakan tentang bahaya infeksi } \\
\text { saluran kemih dengan menjaga } \\
\text { posisi tidur yaitu berbaring miring } \\
\text { ke kiri dan kaki ditinggalkan untuk } \\
\text { mencegah diuresis }\end{array}$ \\
\hline & Striae Gravidarum & a. Gunakan emolien topical atau \\
\hline
\end{tabular}




\begin{tabular}{|l|l|l|}
\hline $\begin{array}{l}\text { Tampak jelas pada } \\
\text { bulan 6-7 }\end{array}$ & $\begin{array}{l}\text { anti prauritik jika ada } \\
\text { indikasinya } \\
\text { b. Gunakan baju longgar yang } \\
\text { dapat menopang payudara dan } \\
\text { abdomen }\end{array}$ \\
\hline Hemmoroid & $\begin{array}{l}\text { a. Hindari konstipasi } \\
\text { b. Gunakan kompres es atau air } \\
\text { hangat }\end{array}$ \\
\hline c. Makan makanan yang berserat \\
dan banyak minum
\end{tabular}




\begin{tabular}{|c|c|}
\hline & $\begin{array}{l}\text { c. Minum cairan dingin atau } \\
\text { hangat terutama saat perut } \\
\text { kosong } \\
\text { d. Istrahat cukup } \\
\text { e. Senam hamil } \\
\text { f. Membiasakan buang air besar } \\
\text { g. Buang air besar segera setelah } \\
\text { ada dorongan. }\end{array}$ \\
\hline $\begin{array}{l}\text { Kram pada kaki setelah } \\
\text { usia kehamilan } 24 \\
\text { minggu }\end{array}$ & $\begin{array}{l}\text { a. Kurangi konsumsi susu } \\
\text { (kandungan fosfornya tinggi) } \\
\text { b. Latihan dorsofleksi pada kaki } \\
\text { dan meregangkan otot yang } \\
\text { terkena } \\
\text { c. Gunakan penghangat untuk otot }\end{array}$ \\
\hline $\begin{array}{l}\text { Mengidam (pica). } \\
\text { Trimester I }\end{array}$ & $\begin{array}{l}\text { a. Tidak perlu dikhawatirkan } \\
\text { selama diet memenuhi } \\
\text { kebutuhan } \\
\text { b. Jelaskan tentang bahaya } \\
\text { makanan yang tidak bisa } \\
\text { diterima, mencakup gizi yang } \\
\text { diperlukan serta memuaskan } \\
\text { rasa mengidam atau kesukaan } \\
\text { menurut kultur. }\end{array}$ \\
\hline $\begin{array}{l}\text { Napas sesak } \\
\text { Trimester II dan III }\end{array}$ & $\begin{array}{l}\text { a. Jelaskan penyebab fisiologinya } \\
\text { b. Dorong agar secara sengaja } \\
\text { mengatur laju dan dalamnya } \\
\text { pernapasan pada kecepatan } \\
\text { normal yang terjadi. } \\
\text { c. Merentangkan tangan diatas } \\
\text { kepala serta menarik napas } \\
\text { panjang } \\
\text { d. Mendorong postur tubuh yang } \\
\text { baik, melakukan pernapasan }\end{array}$ \\
\hline
\end{tabular}




\begin{tabular}{|c|c|}
\hline & interkostal \\
\hline $\begin{array}{l}\text { Nyeri Ligamentum } \\
\text { rotundum }\end{array}$ & $\begin{array}{l}\text { a. Berikan penjelasan mengenai } \\
\text { penyebab nyeri } \\
\text { b. Tekuk lutut ke arah abdomen } \\
\text { c. Mandi air hangat } \\
\text { d. Gunakan bantalan pemanas pada } \\
\text { area yang terasa sakit hanya jika } \\
\text { tidak terdapat kontra indikasi } \\
\text { e. Gunakan sebuah bantal untuk } \\
\text { menopang uterus dan bental } \\
\text { lainnya letakkan di antara lutut } \\
\text { sewaktu dalam posisi berbaring } \\
\text { miring. }\end{array}$ \\
\hline $\begin{array}{l}\text { Berdebar-debar } \\
\text { (palpitasi jantung ) } \\
\text { Mulai akhir trimester I }\end{array}$ & $\begin{array}{l}\text { Jelaskan bahwa hal ini normal pada } \\
\text { kehamilan. }\end{array}$ \\
\hline $\begin{array}{l}\text { Panas perut. } \\
\text { Mulai bertambah sejak } \\
\text { trimester II } \text { dan } \\
\text { bertambah } \\
\begin{array}{l}\text { semakin dengan } \\
\text { kehamilan. Hilangnya }\end{array} \\
\text { pada waktu persalinan }\end{array}$ & $\begin{array}{l}\text { a. Makan sedikit-sedikit tapi sering } \\
\text { b. Hindari makan berlemak dan } \\
\text { berbumbu tajam } \\
\text { c. Hindari rokok,asap } \\
\text { rokok,alcohol dan cokelt } \\
\text { d. Hindari berbaring setelah makan } \\
\text { e. Hindari minum air putih saat } \\
\text { makan } \\
\text { f. Kunyah permen karet } \\
\text { g. Tidur dengan kaki ditinggikan }\end{array}$ \\
\hline Perut kembung & $\begin{array}{l}\text { a. Hindari makanan yang } \\
\text { mengandung gas } \\
\text { b. Mengunyah makanan secara } \\
\text { sempurna } \\
\text { c. Lakukan senam secara teratur } \\
\text { d. Pertahankan kebiasaan buang air } \\
\text { besar secara teratur }\end{array}$ \\
\hline
\end{tabular}




\begin{tabular}{|c|c|}
\hline $\begin{array}{l}\text { Pusing atau sincope } \\
\text { Trimester II dan III }\end{array}$ & $\begin{array}{l}\text { a. Bangun secara perlahan dari } \\
\text { posisi istrahat } \\
\text { b. Hindari berdiri terlalu lama } \\
\text { dalam lingkaran yang hangat } \\
\text { dan sesak } \\
\text { c. Hindari berbaring dalam posisi } \\
\text { telentang }\end{array}$ \\
\hline $\begin{array}{l}\text { Mual dan muntah } \\
\text { Trimester I }\end{array}$ & $\begin{array}{l}\text { a. Hindari bau atau factor } \\
\text { penyebabnya } \\
\text { b. Makan biscuit kering atau roti } \\
\text { bakar sesaat sebelum bangun } \\
\text { c. Makan sedikit tapi sering } \\
\text { d. Duduk tegak setiap kali selesai } \\
\text { makan } \\
\text { e. Hindari makanan yang } \\
\text { berminyak atau berbumbu } \\
\text { f. Istrahat sesuai kebutuhan }\end{array}$ \\
\hline $\begin{array}{l}\text { Sakit punggung atas } \\
\text { dan bawah }\end{array}$ & $\begin{array}{l}\text { a. Gunakan posisi tubuh yang baik } \\
\text { b. Gunakan bra yang menopang } \\
\text { dengan ukuran yang tepat } \\
\text { c. Gunakan kasur yang keras } \\
\text { d. Gunakan bantal ketika tidur } \\
\text { untuk meluruskan punggung }\end{array}$ \\
\hline $\begin{array}{l}\text { Varuses pada kaki } \\
\text { Trimester II dan III }\end{array}$ & $\begin{array}{l}\text { a. Tinggikan kaki sewaktu } \\
\text { berbaring } \\
\text { b. Jaga agar kaki tidak bersilangan } \\
\text { c. Hindari berdiri atau duduk } \\
\text { terlalu lama } \\
\text { d. Senam untuk melancarkan } \\
\text { peredaraan darah } \\
\text { e. Hindari pakaian atau korset yang } \\
\text { ketat. }\end{array}$ \\
\hline
\end{tabular}


16. Tanda bahaya kehamilan

a. Perdarahan per Vaginam

Perdarahan pervaginam dalam kehamilan jarang yang normal/fisiologis. Pada awal kehamilan, ibu mungkin akan mengalami perdarahan sedikit/spotting disekitar waktu pertama terlambat haidnya. Perdarahan ini adalah perdarahan implantasi dan hal tersebut normal terjadi. Pada waktu yang lain dalam kehamilan perdarahan ringan mungkin pertanda dari serviks yang rapuh (erosi). Perdarahan semacam ini mungkin suatu tanda infeksi yang tidak membahayakan nyawa hamil dan janinnya.

Perdarahan pada masa kehamilan yang patologis dibagi menjadi dua yaitu sebagai berikut :

1. Perdarahan pada awal masa kehamilan

Yaitu perdarahan yang terjadi pada masa kehamilan kurang dari 22 minggu. Perdarahan pervaginam dikatakan tidak normal bila ada tanda-tanda berikut :

a. Keluar darah merah

b. Perdarahan yang banyak

c. Perdarahan dengan nyeri

Perdarahan semacam ini perlu dicurigai terjadinya abortus, kehamilan ektopik dan kehamilan molahidatidosa

2. Perdarahan pada masa kehamilan lanjut

Yaitu perdarahan yang terjadi pada kehamilan 22 minggu sampai sebelum persalinan.

Perdarahan tidak normal bila terdapat tanda-tanda berikut ini :

a. Keluar darah merah segar atau kehitaman dengan bekuan 
b. Perdarahan banyak kadang-kadang / tidak terus-menerus

c. Perdarahan disertai rasa nyeri

Perdarahan semacam ini bisa berarti plasenta previa, solusio plasenta dan rupture uteri. Selain itu perlu dicurigai adanya gangguan pembekuan darah.

Diagnosis perdarahan pada kehamilan muda

\begin{tabular}{|c|c|c|c|c|}
\hline Perdarahan & Serviks & Uterus & Gejala/tanda & diagnosis \\
\hline \multirow[t]{3}{*}{$\begin{array}{l}\text { Bercak } \\
\text { hingga } \\
\text { sedang }\end{array}$} & \multirow[t]{2}{*}{ Tertutup } & $\begin{array}{l}\text { Sesuai } \\
\text { dengan } \\
\text { usia gestasi }\end{array}$ & $\begin{array}{l}\text { Kram perut } \\
\text { Uteruslunak }\end{array}$ & $\begin{array}{l}\text { Abortus } \\
\text { imminens }\end{array}$ \\
\hline & & $\begin{array}{l}\text { Serviks } \\
\text { membesar } \\
\text { dari normal }\end{array}$ & $\begin{array}{l}\text { Pingsan } \\
\text { Nyeri perut } \\
\text { bawah } \\
\text { Nyeri goyang } \\
\text { portio } \\
\text { Cairan bebas } \\
\text { Intaabdomen }\end{array}$ & $\begin{array}{l}\text { Kehamilan } \\
\text { Ektopik } \\
\text { Terganggu } \\
\text { (KET) }\end{array}$ \\
\hline & $\begin{array}{l}\text { Tertutup } \\
\text { /terbuka }\end{array}$ & $\begin{array}{l}\text { Lebih kecil } \\
\text { dari gestasi }\end{array}$ & \begin{tabular}{|ll}
\multicolumn{2}{|l}{ Sedikit/tanpa } \\
nyeri & perut \\
bawah & \\
Riwayat & \\
ekspulsi & hasil \\
konsepsi &
\end{tabular} & $\begin{array}{l}\text { Abortus } \\
\text { komplit }\end{array}$ \\
\hline \multirow[t]{3}{*}{$\begin{array}{l}\text { Sedang } \\
\text { hingga } \\
\text { banyak }\end{array}$} & \multirow[t]{2}{*}{ Terbuka } & \multirow[t]{2}{*}{$\begin{array}{l}\text { Sesuai usia } \\
\text { kehamilan }\end{array}$} & $\begin{array}{l}\text { Kram / nyeri } \\
\text { perut bawah } \\
\text { Belumterjadi } \\
\text { ekspulsi hasil } \\
\text { konsepsi }\end{array}$ & $\begin{array}{l}\text { Abortus } \\
\text { insipiens }\end{array}$ \\
\hline & & & $\begin{array}{l}\text { Kram / nyeri } \\
\text { perut bawah } \\
\text { Ekspulsi } \\
\text { sebagian hasil } \\
\text { konsepsi } \\
\end{array}$ & $\begin{array}{l}\text { Abortus } \\
\text { inkomplit }\end{array}$ \\
\hline & Terbuka & $\begin{array}{l}\text { Lunak dan } \\
\text { lebih besar }\end{array}$ & $\begin{array}{l}\text { Mual/muntah } \\
\text { Kram perut }\end{array}$ & $\begin{array}{l}\text { Abortus } \\
\text { mola }\end{array}$ \\
\hline
\end{tabular}




\begin{tabular}{|l|l|l|}
\hline & $\begin{array}{l}\text { dari usia } \\
\text { kehamilan }\end{array}$ & $\begin{array}{l}\text { bawah } \\
\text { Sindrom mirip } \\
\text { preeklamsia } \\
\text { Tak ada janin, } \\
\text { keluar jaringan } \\
\text { seperti anggur }\end{array}$ \\
\hline
\end{tabular}

Diangnosa perdarahan antepartum

\begin{tabular}{|c|c|c|c|}
\hline $\begin{array}{l}\text { Gejala dan tanda } \\
\text { utama }\end{array}$ & $\begin{array}{l}\text { Factor } \\
\text { predisposisi }\end{array}$ & Penyakit lain & Diagnose \\
\hline $\begin{array}{lr}\text { - Perdarahan } & \text { tanpa } \\
\text { nyeri. } & \text { Usia } \\
\text { gestasi } & >22 \\
\text { minggu } & \\
\text { - Darah segar atau } & \text { kehitaman } \\
\text { dengan bekuan } \\
\text { - Perdarahan dapat } \\
\text { terjadir setelah } \\
\text { miksi atau } \\
\text { defekasi, } \\
\text { aktivitas fisik, } \\
\text { kontraksi Braxton } \\
\text { Hicks atau koitus }\end{array}$ & Grande Multipara & $\begin{array}{l}\text { o Syok } \\
\text { o Perdarahan } \\
\text { setelah koitus } \\
\text { o Tidak ada } \\
\text { kontraksi } \\
\text { uterus } \\
\text { o Bagian } \\
\text { terendah janin } \\
\text { tidak masuk } \\
\text { PAP } \\
\text { O Kondisi janin } \\
\text { normal atau } \\
\text { terjadi gawat } \\
\text { janin }\end{array}$ & $\begin{array}{l}\text { Plasenta } \\
\text { Previa }\end{array}$ \\
\hline $\begin{array}{ll}\text { - Perdarahan } & \\
\text { dengan nyeri } \\
\text { intermiten/menet } \\
\text { ap } \\
\text { - Warna daerah } \\
\end{array}$ & $\begin{array}{l}\text { - Hipertensi } \\
\text { - Versi luar } \\
\text { - Trauma }\end{array}$ & 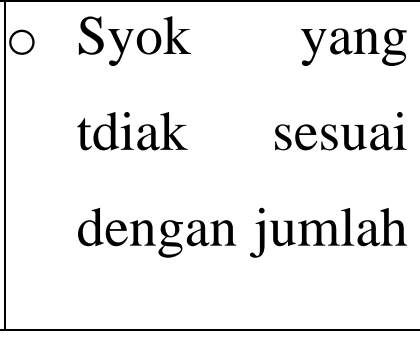 & $\begin{array}{l}\text { Solusio } \\
\text { plasenta }\end{array}$ \\
\hline
\end{tabular}




\begin{tabular}{|c|c|c|c|}
\hline \begin{tabular}{|lr} 
kehitaman & dan \\
cair, & tetapi \\
mungkin & ada \\
bekuan & jika \\
solusio & relative \\
biru & \\
- Jika & ostium \\
terbuka & terjadi \\
perdarahan & \\
berwarna & merah \\
segar. &
\end{tabular} & $\begin{array}{l}\text { abdomen } \\
\text { - Polihidroamnio } \\
\text { n } \\
\text { - Gemeli } \\
\text { - Defisiensi gizi }\end{array}$ & $\begin{array}{l}\text { daerah yang } \\
\text { keluar } \\
\text { o Anemia berat } \\
\text { Melemah atau } \\
\text { hilangnya } \\
\text { gerak janin } \\
\text { Gawat janin } \\
\text { atau hilangnya } \\
\text { denyut janin } \\
\text { Uterus tegang } \\
\text { dan nyeri }\end{array}$ & \\
\hline $\begin{array}{l}\text { - Perdarahan } \\
\text { intraabdominal } \\
\text { dan atau vaginal } \\
\text { - Nyeri hebat } \\
\text { sebelum } \\
\text { perdarahan dan } \\
\text { syok, yang } \\
\text { kemudian hilang } \\
\text { setelah regangan } \\
\text { hebat pada perut } \\
\text { bawah }\end{array}$ & $\begin{array}{l}\text { - Riwayat Sc } \\
\text { - Partus lama atau } \\
\text { kasep } \\
\text { - Disptoporsi } \\
\text { kepala } \\
\text { - Kelainan } \\
\text { letak/presentasi } \\
\text { - Persalinan } \\
\text { traumatic }\end{array}$ & $\begin{array}{l}\text { o Syok atau } \\
\text { takikardia } \\
\text { o Adanya cairan } \\
\text { bebas } \\
\text { aintrabdominal } \\
\text { o Hilangnya } \\
\text { gerak dan DJJ } \\
\text { O Bentuk uterus } \\
\text { abnormal atau } \\
\text { konturnya } \\
\text { tidak jelas } \\
\text { Nyeri } \\
\text { raba/tekan } \\
\text { dinding perut }\end{array}$ & $\begin{array}{l}\text { Ruptur } \\
\text { Uteri }\end{array}$ \\
\hline
\end{tabular}




\begin{tabular}{|c|c|c|c|}
\hline & & $\begin{array}{l}\text { dan bagian } \\
\text { janin mudah } \\
\text { dipalpasi. }\end{array}$ & \\
\hline 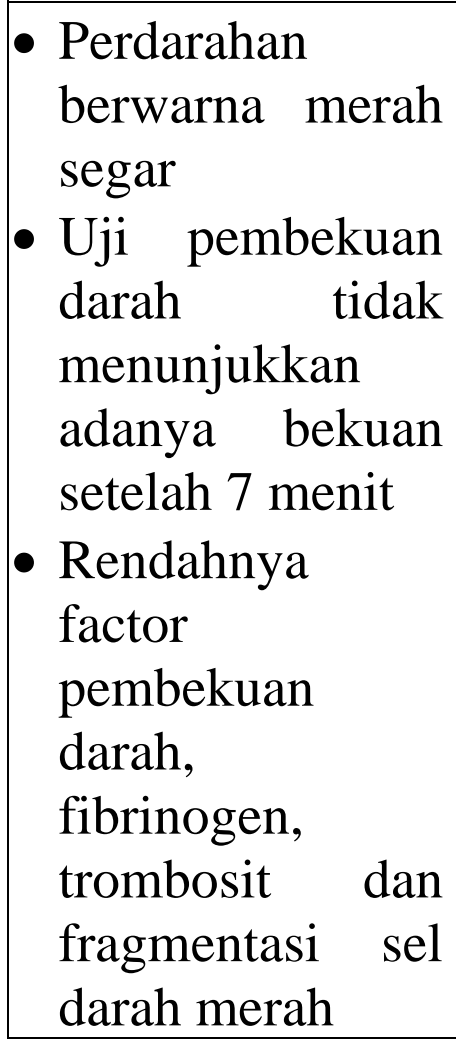 & $\begin{array}{l}\text { - Solusio plasenta } \\
\text { - Janin mati } \\
\text { dalam Rahim } \\
\text { - Eklamsia } \\
\text { - Emboli air } \\
\text { ketuban }\end{array}$ & $\begin{array}{l}\text { o Perdarahan } \\
\text { gusi } \\
\text { Gambaran } \\
\text { memar bawah } \\
\text { kulit } \\
\text { O Perdarahan } \\
\text { dari tempat } \\
\text { suntikan dan } \\
\text { jarum infus }\end{array}$ & $\begin{array}{l}\text { Gangguan } \\
\text { pembekuan } \\
\text { darah }\end{array}$ \\
\hline
\end{tabular}

b. Sakit kepala yang hebat

Sakit kepala yang hebat dapat terjadi selama kehamilan dan sering kali merupkan ketidaknyamanan yang normal dalam kehamilan. Sakit kepala yang menunjukkan suatu masalah yang serius adalah sebagai berikut :

1. Sakit kepala hebat

2. Sakit kepala menetap

3. Tidak hilang dengan istrahat

Terkadang dengan sakit kepala yang hebat tersebut, ibu mungkin menemukan bahwa penglihatannya menjadi kabur atau 
berbayang. Sakit kepala yang hebat dalam kehamilannya adalah gejala dari preeklamsia

Hal ini disebabkan terjadinya edema pada otak dan meningkatnya retensi otak yang mempengaruhi system saraf pusat yang dapat menimbulkan kelainan serebral (nyeri kepala,kejang) dan gangguan penglihatan.

c. Penglihatan kabur

Masalah Penglihatan Kabur. Penglihatan ibu dapat berubah dalam kehamilan. Perubahan ringan (minor) adalah normal. Masalah visual yang mengidentifikasikan keadaan yang mengancam jiwa adalah perubahan visual mendadak misalnya penglihatan kabur atau berbayang, melihat bintik-bintik (spot) dan berkunang-kunang.

Selain itu, adanya skotoma, diplopia dan ambiliopia merupakan tanda-tanda yang menunjukkan adanya preeklamsia berat yang mengarah pada eklamsia. Hal ini disebabkan adanya perubahan peredaraan darah dalam pusat penglihatan di korteks serebri atau dalam retina (edema retina dan spasme dalam pembuluh darah). Perubahan penglihatan ini mungkin juga disertai dengan sakit kepala yang hebat. Diagnosis nyeri kepala, gangguan penglihatan kejang atau koma dan hipertensi.

d. Bengkak pada muka dan tangan

Edema adalah penimbunan cairan secara umum dan berlebihan dalam jaringan tubuh dan biasanya dapat diketahui dari kenaikan berat badan serta pembengkakan kaki, jari tangan dan muka. Edema pretibial yang ringan sering ditemukan pada 
kehamilan biasa sehingga tidak seberapa penting untuk penentuan diagnosis preeklamsia. Selain itu, kenaikan BB $1 / 2 \mathrm{~kg}$ setiap minggunya dalam kehamilan masih dianggap normal tetapi bila kenaikan $1 \mathrm{~kg}$ seminggu beberapa kali mkan perlu kewaspadaan teradap timbulnya preeklamsia.

Hampir separuh dari ibu-ibuakan mengawali bengkak yang normal pada kaki yang biasanya hilang setelah beristrahat atau meninggikan kaki. Bengkak dapat menunjukkan adanya masalah apabila ditandai dengan tanda-tanda berikut ini :

1. Jika muncul pada muka dan tangan

2. Bengkak tidak hilang setelah beristrahat

Bengkak disertai dengan keluhan fisik lainnya seperti sakit kepala yang hebat, pandangan mata kabur. Hal ini dapat merupakan pertanda anemia gagal jantung atau preeklamsia.

e. Nyeri perut yang hebat

Nyeri abdomen yang tidak berhubungan dengan persalinan normal adalah tidak normal. Nyeri abdomen yang mungkin menunjukkan masalah yang mengancam keselamatan jiwa adalah yang hebat, menetap dan tidak hilang setelah beristrahat. Hal ini bisa berarti apendisitis,kehamilan ektopik,aborsi, penyakit radang panggul, persalinan preterm, gastritis, abrupsio plasenta, infeksi saluran kemih atau infeksi.

f. Gerakan bayi yang berkurang

Gerakan janin adalah suatu hal yang biasa terjadi pada kehamilan yaitu pada usia kehamilan 20-24 minggu. Ibu mulai 
merasakan gerak bayinya selama bulan ke-5 atau ke-6, beberapa ibu dapat merasakan gerakan bayinya lebih awal.

Gerakan janin tersebut dipengaruhi oleh berbagai hal yaitu umur kehamilan,transport glukosa, stimulus pada suara, kebiasaan janin, ibu yang merokok dan penggunaan obat-obatan oleh ibu hamil. Bayi harus bergerak paling sedikit 3 ali dalam periode 3 jam. Gerakan janin akan lebih mudah terasa jika ibu berbaring atau beristirahat serta jika ibu makan dan minum dengan baik.

Hal yang paling penting bahwa ibu hamil perlu waspada terhadap jumlah gerakan janin ibu hamil perlu melaporkan jika terjadi penurunan gerakan janin terhenti.

Menilai gerakan janin yang berkurang dapat dilakukan dengan metode perhitungan Gerakan janin oleh Cardiff Count to ten.

a. Perhitungan sekali dalam sehari

b. Buat standar perhitungan pada waktu yang sama contoh tiap 8 jam pagi atau tanyakan kepaa wanita untuk memilih waktu yang dipunyai dan ketika janin biasanya aktif.

c. Catat berapa lama yang dibutuhkan untuk mencapai 10 gerakan

d. Harus ada sedikitnya 10 gerakan yang teridentifikasi selama 10 jam.

e. Jika kurang dari 10 gerakan dalam 10 jam atau jika terjadi peningkatan waktu kurang dari 10 gerakan atau tidak ada gerakan selama 10 jam, maka uji NST harus dilakukan secepatnya. 


\section{Cara mengidentifikasi tanda-tanda kehamilan adalah sebagai berikut :}

1. Identifikasi perdarahan per vaginam pada ibu hamil

a. Tanyakan pada ibu hamil mengenai karakteristik perdarahan, kapan mulainya, seberapa banyak, apa warnanya dan adakah gumpalan

b. Tanyakan pada ibu hamil apakah ia merasakan nyeri/sakit ketika mengalami perdarahan

c. Periksa tekanan darah,suhu,nadi dan DJJ

d. Lakukan pemeriksaan ekternal (luar), rasakan apakah perut bagian bawah lembut pada perabaan, lakukan pemeriksaan speculum (jika memungkinkan).

e. Jangan lakukan pemeriksaan dalam untuk perdarahan trimester ketiga.

2. Identifikasi sakit kepala yang hebat pada ibu hamil

a. Tanyakan pada ibu hamil jika ia mengalami edema pada muka/tangan atau masalah visual

b. Periksa tekanan darah,protein urine, reflex dan edema/bengkak

c. Periksa suhu dan jika tinggi, pikirkan untuk melakukan pemeriksaan darah untuk mengetahui adanya malaria.

d. Identifikasi masalah penglihatan pada ibu hamil

e. Periksa tekanan darah,protein urine,reflex dan edema

3. Identifikasi bengkak pada muka dan tangan ibu hamil

a. Tanyakan pada ibu apakah ia mengalami sakit kepala atau masalah visual 

b. Periksa adanya pembengkakan
c. Ukur tekanan darah dan protein urine ibu

4. Identifikasi nyeri perut yang hebat

a. Tanyakan pada ibu tentang karakteristik dan kapan nyeri terjadi seberapa hebat kapan mulai dirasakan.

b. Tanyakan pada ibu apakah ia mempunyai tanda/gejala lain yang dapat mambantu bidan menegangkan diagnosis seperti adanya perdarahan,demam,diare .

c. Ukur tekanan darah, suhu,nadi.

d. Periksa protein urine

5. Identifikasi gerakan bayi yang berkurang

a. Tanyakan pada ibu kapan terakhir bayinya bergerak

b. Dengarkan denyut jantung janin.

g. Kejang

h. Ketuban pecah dini

Dinamakan ketuban pecah sebelum waktunya apabila terjadi sebelum persalinan yang disebabkan karena berkurangnya kekuatan membran/ peningkatan tekanan uteri yang juga dapat disebabkan adanya infeksi yang dapat berasal dari vagina dan serviks yang dapat dinilai dari cairan ketuban di vagina. Pecahnya selaput ketuban dapat terjadi pada kehamilan 37 minggu preterm maupun kehamilan aterm.

\section{Kebutuhan Psikologis Ibu Hamil Trimester I,II,III}

Selama hamil, kebanyakan perempuan mengalami perubahan psikologis dan emosional. Seringkali kita mendengar seorang perempuan mengatakan betapa bahagianya dia karena akan menjadi 
seorang ibu dan dia telah memilihkan sebuah nama untuk bayi yang akan dilahirkannya. Namun tidak jarang ada perempuan yang merasa khawatir kalau selalu terjadi masalah dalam kehamilannya, khawatir kalau ada kemungkinan bayinya tidak normal. Sebagai seorang bidan, harus menyadari adanya perubahan-perubahan pada perempuan hamil agar mampu memberikan dukungan dan memperhatikan keprihatinannya, kekhawatirannya dan pernyataan-pernyataannya.

\section{Dukungan Keluarga}

a. Ayah-ibu kandung maupun mertus sangat mendukung kehamilan

b. Ayah-ibu kandung maupun mertua sering berkunjung dalam periode ini

c. Seluruh keluarga berdoa untuk keselamatan ibu dan bayi

d. Walaupun ayah-ibu kandung maupun mertua ada diaderah lain, sangat didambakan dukungan melalui telepon, surat atau doa dari jauh

e. Selain itu, ritual tradisional dalam periode ini seperti upacara 7 bulanan pada beberapa orang mempunyai arti tersendiri yang tidak boleh diabaikan.

\section{Dukungan dari tenaga kesehatan}

a. Aktif-melalui kelas antenatal

b. Pasif-dengan memberi kesempatan pada mereka yang mengalami masalah untuk berkonsultasi

c. Tenaga kesehatan harus mampu mengenali keadaan yang ada disekitar ibu hamil/pasca bersalin yaitu bapak (suami ibu bersalin), kakak (saudara kandung dari calon bayi/sibling) serta factor penunjang. 


\section{Rasa aman dan nyaman Selama kehamilan}

Peran keluarga, khususnya suami sangat diperlukan bagi seorang perempuan hamil. Keterlibatan dan dukungan yang diberikan suami guna kehamilan akan mempererat hubungan antara ayah anak dan suami istri. Dukungan yang diperoleh oleh ibu hamil akan membuatnya lebih tenang dan nyaman dalam kehamilan yang sehat. Dukungan yang dapat diberikan oleh suami misalnya dengan mengantar ibu memeriksakan kehamilan, memenuhi keinginan ibu hamil mengidam, mengingatka minum tablet zat besi, maupun membantu ibu melakukan kegiatan rumah tangga selama ibu hamil. Walau suami melakukan hal kecil, tindakan tersebut mempunyai makna yang berarti dalam meningkatkan kesehatan psikologis ibu hamil kea rah yang lebih baik.

\section{Persiapan menjadi orang tua}

Kehamilan dan peran sebagai orang tua dapat dianggap sebagai masa transisiatau peralihan. Terlihat adanya peralihan yang sangat besar akibat kelahiran dan peran yang baru serta ketidakpastian yang terjadi sampai peran yang baru ini dapat disatukan dengan anggota keluarga yang baru.

\section{Persiapan saudara kandung}

a. Sibling (kakak)

1. Respon kaka katas kelahiran seorang bayi laki-laki atau perempuan bergantung pada usia dan tingkat perkembangan.

2. Biasanya balita kurang sadar akan adanya kelahiran.

3. Mereka mungkin melihat pendatang baru sebagai saingan atau mereka takut akan kehilangan kasih saying orang tua 
4. Tingkah laku negative mungkin muncul dan merupakan petunjuk derajat stress pada kakak

5. Tingkah laku negative ini mungkin berupa masalah tidur, peningkatan usaha untuk menarik perhatian, kembali ke pola tingkah laku kekanank-kanakan seperti mengompol atau mengisap jempol.

6. Beberapa anak mungkin menunjukkan tingkah laku bermusuhan terhadap ibu, terutama bila ibu menggendong bayi atau memberi makan

7. Tingkah laku ini merupakan manifestasi rasa iri dan frustasi yang dirasakan kakak bila mereka melihat perhatian ibu diberikan kepada orang lain

8. Orang tua harus mencari kesempatan-kesempatan untuk menegaskan kembali kasih saying mereka kakak yang sedang rapuh ini.

9. Anak pra sekolah mungkin akan lebih banyak melihat dari pada menyentuh

10. Sebagian besar akan menghabiskan waktu dekat dengan bayi dan berbicara kepada ibu tentang bayi ini.

11. Lingkungan yang rileks dan biasa tanpa dibatasi waktu akan mempermudah interaksi anak-anak yang muda dengan bayi.

12. Kakak harus diberikan perhatian khusus oleh orang tua, penunjang dan bidan yang sepadan dengan yang diberikan kepada bayi baru lahir.

b. Adaptasi kakak

1. Balita 
a) Bagaimana cara kakak menyesuaikan diri dengan kelahiran bayi akan sangat bergantung pada usia dan tingkat perkembangan anak-anak.

b) Anak-anak yang masih sangat muda, 2 tahun atau kurang, tidak menyadari perubahan pada ibunya yang sedang hamil dan tidak mengerti bahwa akan lahir seorang adik laki-laki atau perempuan karena balita belum mempunyai persepri waktu.

c) Banyak orang tua yang menangguhkan pemberitahuan sampai dekat dengan saat kelahiran

d) Meski sulit mempersiapkan anak yang masih sangat muda untuk menyongsong kelahiran bayi, seorang bidan dapat memberikan saran yang membantu.

e) Pertama, segala perubahan dalam susunan tidur bersama harus dibuat beberapa minggu sebelum kelahiran, supaya balita tersebut tidak merasa disingkirkan oleh bayi yang baru lahir.

f) Kedua, orang tua dapat mempersiapkan keluarga dan kawankawan mereka untuk bertanya pada sibalita apakah dia iri dan menyesali adanya adik, bagaimana apabila si balita harus berbagi waktu dan perhatian dengan sibayi.

g) Sangat penting untuk diyakinkan berulang kali terutama bagi orang tua mengenai kasih saying mereka kepada si balita.

h) Hanya apabila si balita merasa aman terhadap kasih saying orang tuanya, baru dapat diharapkan seorang anak berumur 2 tahun bersedia menyongsong keadatngan orang lain. 
i) Dapat diajarkan kepada orang tua untuk menerima perasaan kuat/hebat yang diperlihatkan balita seperti marah,iri atau kesal tanpa menghakimi dan selalu memperkuat kasih sayang pada anak.

2. Anak yang lebih tua

a) Anak yang lebih tua, usia 3-12 tahun, lebih sadar akan perubahan-perubahan tubuh ibunya dan mungkin menyadari akan terjadinya kelahiran bayi.

b) Anak-anak ini mungkin akan tertarik untuk memperhatikan perut ibu, dan merasakan pergerakan janin. Mereka akan senang mendengarkan denyut jantung janin dan mungkin mempunyai beberapa pertanyaan tentang cara bayi dikeluarkan dari perut.

c) Merka umumnya mengerti bahwa bayi kemungkinan adik laki-laki atau perempuan dan sangat menunggu kehadiran bayi.

d) Namun mereka mungkin mengharapka bayi yang lahir langsung sudah bisa diajak bermain dan sering kaget melihat betapa kecil dan tak berdayanya si bayi.

e) Anak-anak yang telah sekolah akan mendapat keuntungan bila di ikutsertakan dalam persiapan menyongsong bayi

f) Mereka seringkali senang mengukur besar dan perkembangan janin lalu mencatatnya di kalender

g) Mereka tertarik untuk mempersipakan tempat tidur bayi dan mengumpulkan barang-barang keperluan bayi 
h) Anak-anak ini harus diajak untuk merasakan pergerakan janin dan banyak diantara mereka yang mendekat ke perut ibu dan berbicara pada janin.

i) Anak-anak yang lebih tua juga mendapat rasa tenteram dan menikmati waktu bersama orang tua.

3. Remaja

a) Respon para remaja juga bergantung pada tingkat perkembangan mereka

b) Ada remaja yang malu karena kehamilan, sebab berarti ada hubungan seksual antara orang tua mereka

c) Mereka mungkin jijik melihat perubahan fisik ibu

d) Banyak remaja yang sangat larut dalam perkembangan mereka sendiri, biasanya berupa pengenduran ikatan kepada orang tua dan menghadapi perkembangan suksualitas mereka sendiri.

e) Mereka mungkin tidak peduli terhadap kehamilan, kecuali bila mengangganggu kegiatan mereka. Namun ada remaja yang justru menjadi sangat terlibat dan ingin membantu berbagai persiapan untuk bayi. 


\section{BAB VI \\ ASUHAN KEHAMILAN}

\section{A. Pendahuluan}

\section{Deskripsi Singkat}

Pokok bahasan ini akan membahas asuhan kehamilan kunjungan awal, kunjungan ulang, asuhan kebidanan pada setiap kunjungan. .

2. Tujuan Instruksional Khusus (TUK)

Setelah mengikuti mata kuliah ini mahasiswa diharapkan mampu memberikan asuhan kebidanan selama kehamilanyang meliputi kunjungan awal, ulang dan komprehensif.

\section{B. Asuhan Kehamilan Kunjungan Awal}

1. Tujuan Asuhan Antenatal

Tujuan utama asuhan antenatal adalah untuk memastikan hasil yang sehat dan positif bagi ibu maupun bayinya dengan cara-cara sebagai berikut

a. Memantau kemajuan kehamilan untuk memastikan kesehatan ibu dan tumbuh kembang bayi

b. Meningkatkan dan mempertahankan kesehatan fisik, mental serta social ibu dan bayi

c. Mengenali secara dini adanya ketidaknormalan atau komplikasi yang mungkin terjadi selama kehamilan.

d. Mempersiapkan peran ibu dan keluarga dalam menerima kelahiran bayi.

2. Tujuan Kunjungan 
a. Mengumpulkan informasi mengenai ibu hamil untuk membantu bidan dan membangun hubungan kepercayaan dengan ibu tersebut

b. Mendeteksi komplikasi yang mungkin terjadi

c. Menggunakan data untuk menghitung usia kehamilan dan tanggal persalinan

d. Merencanakan asuhan khusus yang dibutuhkan ibu.

3. Pengkajian Data Ibu Hamil/Anamnesis

a. Maksud dari anamnesis adalah mendeteksi komplikasi dan menyiapkan kelahiran dengan mempelajari keadaan kehamilan dan kelahiran terdahulu serta kesehatan umum data kondisi social ekonomi

b. Ketika melakukan anamnesis diperlukan keterampilan berkomunikasi yang baik karena cara seorang bidan melakukan komunikasi dengan ibu menentukkan informasi apa dan berapa banyak yang dapat diperoleh dari ibu tersebut.

4. Isi Riwayat pada Kunjungan Antenatal Pertama

a. Informasi biodata

Identitas ibu dan suami (nama, umur, pekerjaan, agama, suku, alamat). Informasi yang dimaksud berisi identitas umum, perhatian pada usia ibu, status perkawinan dan tingkat pendidikan. Usia reproduksi sehat dan aman adalah antara 20-30 tahun. Pada kehamilan usia remaja, apalagi kehamilan diluar nikah kemungkinan ada unsur penolakan psikologis yang tinggi. Tidak jarang pasien meminta aborsi. Usia muda juga factor kehamilan risiko tinggi untuk memungkinkan adanya komplikasi 
obstetric seperti preklamsia, ketuban pecah dini, persalinan preterm dan abortus.

b. Keluhan utama

Sadar/tidak akan kemungkinan hamil, apakah semata-semata ingin periksa hamil atau ada keluhan/ masalah lain yang dirasakan.

c. Riwayat kehamilan sekarang meliputi :

1) HPHT dan apakah siklus menstruasi normal

2) Gerak janin (kapan mulai dirasakan dan apakah ada perubahan yang terjadi

3) Masalah dan tanda-tanda bahaya (termasuk rabun senja)

4) Keluhan-keluhan lazim pada kehamilan

5) Penggunaan obat-obatan(termasuk jamu-jamuan)

6) Kekhawatiran lain yang dirasakan

Pada kehamilan sekarng membantu anda untuk menentukan umur kehamilan dengan tepat. Setelah mengetahui umur kehamilan ibu,dapat memberikan konseling tentang keluhan kehamilan yang biasa terjadi dan dapat mendeteksi adanya komplikasi dengan lebih baik.

1. Riwayat kebidanan yang lalu meliputi :

a. Jumlah kehamilan, anak yang lahir hidup, persalinan yang aterm, persalinan yang premature, keguguran atau kegagalan kehamilan, persalinan dengan tindakan (forcep atau SC).

b. Riwayat perdarahan pada kehamilan,persalinan,atau nifas sebelumnya. 
c. Hipertensi disebabkan kehamilan sekarang atau kehamilan sebelumnya

d. Berat bayi sebelumnya $<2500$ gram atau $>4000$ gram.

e. Masalah-masalah lain yang dialami.

Riwayat kebidanan yang lalu membantu anda mengelola asuhan pada kehamilan ini (konseling khusus, tes, tindak lanjut dan rencana persalinan.

Contoh I :

Seorang wanita yang memiliki riwayat perdarahan pascasalin diperlukan adanya hal berikut :

a. Pencegahan anemia

b. Melahirkan dengan tenaga terlatih yang terampil dalam penatalaksanaan

c. Memilih cairan infus, oksitosin dan metergin yang tersedia dalam persalinan

d. Perencanaan sama transportasi jika dibutuhkan kegawatdaruratan

e. Donor darah yang telah diketahui golongan darahnya.

Contoh II.

Seorang wanita yang memiliki riwayat hipertensi pada kehamilan yang lalu, membutuhkan hal-hal berikut :

a. Konseling mengenai tanda bahaya eklamsia seperti pandangan kabur, nyeri ulu hati, sakit kepala yang hebat, edema pada wajah dan tangan.

b. Penentuan tekanan darah,reflex dan protein urine diteliti 
c. Perencanaan sarana transportasi jika dibutuhkan kegawatdaruratan

2. Riwayat kesehatan termasuk penyakit-penyakit yang didapat dahulu dan sekarang

a. Masalah kardiovaskuler

b. Hipertensi

c. Diabetes

d. Malaria

e. PMS

Riwayat kesehatan yang lalu dan sekarang membantu anda mengidentifikasi kondisi kesehatan yang dapat mempengaruhi kehamilan atau bayi baru lahir

3. Riwayat social-ekonomi meliputi hl-hal sebagai berikut:

a. Status perkawinan

b. Respons orang tua dan keluarga terhadap kematian

c. Riwayat KB

d. Dukungan keluarga

e. Pengambil keputusan dalam keluarga

f. Kebiasaan makan dan gizi yang di konsumsi merokok dan minum obat atau alcohol

g. Beban kerja dan kegiatan sehari-hari

h. Kebiasaan hidup sehat meliputi kebiasaan merokok dan minum obat atau alcohol

i. Tempat melahirkan dan penolong yang diinginkan 
Riwayat social-ekonomi ibu dapat membantu untuk mengetahui system dukungan terhadap ibu dan pengambilan keputusan dalam keluarga sehingga anda dapat membantu ibu merencanakan persalinannya yang lebih baik.

\section{Menghitung Perkiraan Tanggal Persalinan}

\section{Metode Kalender}

Rumus Naegle hari pertama haid terakhir $+7-3$ bulan = tanggal persalinan

Rumus Neagle hanya dapat dipakai apabila haid ibu teratur. Rumus ini tidak dapat digunakan terdapat hal-hal berikut :

1. Ibu mempunyai riwayat haid tidak teratur dan tidak haid (amenorrhea)

2. Ibu sudah hamil saat masih menyusui dan belum pernah haid lagi sesudah melahirkan

3. Ibu hamil setelah berhenti mengonsumsi pil KB dan belum haid lagi

Kalau salah satu dari situasi diatas terjadi, perkiraan tanggal persalinan dilakukan secara klinis (misalnya dengan melihat besarnya uterus atau dengan menggunakan ultrasound.

Contoh penggunaan Rumus Naegle :

Mulai dari hari pertama haid terakhir dan tambahkan 7 hari. Kemudian hitung kebelakang 3 bulan (perhatikan baik-baik, gunakan jari tangan dan/ atau tuliskan kerta untuk memudahkanny).

HPHT : 5 Mei 2017

TP : :12 Februari 2018 
5. Pemeriksaan Fisik dan Tes Laboratorium

Tujuan dari pemeriksaan fisik dan tes laboratorium adalah untuk mendeteksi komplikasi-komplikasi kehamilan. Bukti diseluruh dunia menunjukkan bahwa pemeriksaan fisik dan tes laboratorium selama kunjungan antenatal harus difokuskan pada pemeriksaan-pemeriksaan yang didukung oleh riset ilmiah. Dengan kata lain, bidan harus melakukan pemeriksaan yang nyata agar dapat menurunkan angka kemtian ibu dan neonates.

1. Pemeriksaan fisik umum :

a. Tinggi badan

b. Berat badan

c. Tanda-tanda vital (TD,suhu,nadi)

2. Kepala dan leher

a. Edema di wajah

b. Icterus pada mata

c. Bibir pucat

d. Leher meliputi pembengkakan saluran limfe atau pembengkakan kelenjar tiroid dan vena jugularis

3. Tangan dan kaki
a. Edema di jari tangan
b. Kuku jari pucat
c. Varises vena
d. Reflex -refleks

4. Payudara

a. Ukuran,kesimetrisan 

b. Putting payudara menonjol/masuk
c. Keluarnya kolostrum atau cairan lain
d. Retraksi, disipling
e. Massa
f. Noudul aksila

5. Abdomen

a. Luka bekas operasi

b. TFU (jika $>12$ minggu)

c. Letak,presentasi,posisi dan penurunan kepala (kalau >36 minggu).

Inspeksi : membesar/tidak (pada kehamilan muda pembesaran abdomen mungkin belum nyata)

Palpasi : tentukan tinggi fundus uteri (pada kehamilan muda dilakukan dengan palpasi bimanual dalam, ukuran uterus baru dapat diperkirakan saat kehamilan sudah lebih besar. Tinggi fundus dapat diukur dengan pita ukuran sentimeter (jarak antara fundus uteru dengan tepi atas simpisis os pubis).

Pemeriksaan palpasi leopold dilakukan dengan sistematika berikut :

a. Leopold I

Menentukan tinggi fundus uteri dan meraba bagian janin yang berada di fundus engan kedua telapak tangan.

\section{b. Leopold II}

Kedua telapak tangan menekan uterus dari kiri-kanan, jari kea rah kepala pasien, mencari sisi bagian besar (biasanya punggung) janin, atau mungkin bagian keras bulat (kepala) janin. 


\section{c. Leopold III}

Satu tangan meraba bagian janin apa yang terletak di bawah (diatas simfisis) sementara tangan lainnya menahan fundus untuk fiksasi.

\section{d. Leopold IV}

Kedua tangan menekan bagian bawah uterus dari kiri-kanan,jari kearah kaki pasien, untuk konfirmasi bagian terendah janin dan menentukan apakah bagian tersebut sudah masuk/melepasi pintu atas panggul (biasanya dinyataka dengan satuan X/5).

Jika memungkinkan dalam palpasi diperkirakan juga taksiran berat janin (meskipun kemungkinan kesalaha juga masih cukup besar). Pada kehamilan aterm,perkiraan berat janin dapat menggunakan rumus Johnson-Tossec yaitu Tinggi fundus (cm)(12x155 gram)

\section{e. DJJ (bila $>18$ minggu)}

Auskultasi : dengan stetoskop kayu Laenec atau alat Doppler yang di tempelkan di daerah punggung janin, dihitung frekuensi pada 5 detik pertama,ketiga,dan kelima kemudian di jumlah dan dikalikan 4 untuk memperoleh frekuensi satu menit. Sebenarnya pemeriksaan auskultasi yang ideal adalah denyut jantung janin dihitung seluruhnya selama satu menit. Batas frekuensi denyut jantung janin normal adalah 120-160 x/menit. Takikardi menunjukkan adanya reaksi kompensasi terhadap bebab stress pada janin (fetal stress) sementara bradikardi menunjukkan kegagalan kompensasi beban/stress pada janin (fetal distress/gawat janin). 


\section{TRIMESTER I}

1.Pemeriksaan dilakukan sampai usia kehamilan 13 minggu

2.Informasi yang dikumpulkan meliputi riwayat kesehatan dan pengkajian fisik ibu

a. Auskutltasi DJJ

Dapat digunakan alat ultrasound stetoskope/Doppler. Djj bisa terdengar dengan alat ini antara usia kehamilan 10-12 minggu. Normal frekuensi DJJ adala 120-160x/menit dan harus dibedakan dengan denyut nadi ibu.

b. USG

Adalah suatu pemeriksaan yang menggunakan gelombang ultrasonic untuk mendapatkan gambaran dari janin,plasenta dan uterus.

Secara umum USG digunakan untuk menilai :

- Taksiran usia kehamilan

- Lokasi plasenta

- Pengawasan pertumbuhan dan pergerakan janin

- Deteksi kehamilan ganda

- Identifikasi kelaian bawaan

- Menilai keadaan/ukuran panggul dalam.

Selama trimester I,USG dapat digunakan untuk :

- Mengkaji usia kehamilan

- Mengevaluasi diagnosis perdarahan pervaginam

- Memastikan dugaan kehamilan kembar

- Mengevaluasi pertumbuhan janin

- Mengevaluasi masa pelvik 
Kandung kemih yang oenuh akan meningkatkan kepekaan ultraosnik, terutama pada usia kehamilan 20 minggi atau kurang. Kandung kemih yang penuh akan dapat mengangkat uterus keuar dari rongga panggul, sehingga didapatkan gambar yang baik. Selama pemeriksaan pasien telentang \pm 30 menit. Jeli akan dioleskan disekeliling permukaan kulit perut sebagai media konduktif bagi ultrasound, disamping untuk mengurangi gesekan dari transduktif bagi ultrasound disamping untuk mengurangi gesekan dari transduser digerakgerakkab di permukaan kulit.

\section{TRIMESTER II}

Pengukuran TFU dapat dilakukan dengan :

1. Menggunakan meteran menurut Mc.Donalds

Dianggap akurat bila dilakukan setelah usia kehamilan 20 minggu. TFU dinyatakan dengan Centimeter $(\mathrm{cm})$. bila usia kehamilan di bawah 20 minggu digunakan dengan cara palpasi leopold I.

Cara pengukuran TFU dengan $\mathrm{cm}$ bisa pula membantu pengukuran perkiraan beat janin dengan rumus dari Johson Tausak :

\section{(TFU(dalam cm)-12)x155=TBJ dalam gram.}

2. Bila TFU lebih besar dari usia kehamilan,bisa berarti :
a. Kehamilan ganda
b. Polihihdroamnion
c. Makrosomia janin
d. Mol hydatidosa

3. Bila TFU lebih kecil dari usia kehamilan, kemungkinan terdapat :

a. Gangguan pertumbuhan janin

b. Kelainan bawaan 
c. Oligohydroamnion

Selama kehamilan trimester II, pengkajian DJJ dilakukan dengan stetoscope monocular/stetoscope Laenec.

Teknik Pemeriksaan:

1. Tentukan letak/posisi janin menggunakan teknik palpasi menurut Leopold II dan III

2. Tempelkan stetoscope pada lokasi dimana diperkirakan terletak punggung atau dada janin

3. Bedakan DJJ dan denyut nadi ibu dengan cara meraba nadi dipergelangan tangan ibu.

4. Hitung DJJ,kemudian jumlahkan dan dikalikan 4,didapatkan frekuensi DJJ per menit

Pada primigravida, gerakjanin dirasakan pertama kali oleh ibu pada usia kehamilan 18-20 minggu, sedang pada multigravida dapat dirasakan lebih awal yaitu usia 16 minggu.

USG digunakan selama kehamilan trimester II untuk :

1. Mengkaji usia kehamilan

2. Mendiagnosa kehamilan ganda

3. Mengkaji pertumbuhan janin

4. Mengidentifikasi struktur abnormal janin

5. Mengkaji lokasi plasenta.

\section{TRIMESTER III}

1. Sebaiknya ibu hamil mengamati geraan janin setiap hari setelah usia kehamilan 28 minggu dengan cara setiap hari ibu diminta untuk berbaring miring dan meraba perutnya untuk merasakan gerakan janin. Hitung berapa gerakan yang terjadi. 
2. Pada umunya 10 gerakan terjadi dalam jangka waktu 20 menit hingga 2 jam. Bila melebihi jangka waktu 3 jam maka harus dicatat dan diadakan pengawasan lebih cermat terhadap DJJ.

3. Informasi yang diberikan pada ibu hamil :

Pergerakan janin akan bertambah setelah makan

Pergerakan ibu dapat membuat pergerakan janin lebih aktif

$>$ Janin yang normal akan tidru selama kurang lebih 20 menit

$>$ Selama 2-3 minggu sebelum lahir,aktivitas normal janin berkurang

Selama trimester III, USG digunakan untuk mengetahui posisi janin dan taksiran ukuran/berat janin. Lingkar perut dan panjang femur merupakan patokan dalam menaksir berat janin dan interval pertumbuhan.

\section{Asuhan Kehamilan Kunjungan Ulang}

Daftar berikut meliputi komponen-komponen utama kunjungan ulang antenatal. Pengkajian yang sedang berjalan dari poin-poin tersebut dan asuhan dari setiap masalah yang ditemukan tampaknya memengaruhi hasil-hasil pemeriksaan ibu dan anak.

1. Riwayat kehamilan sekarang

a. Menanyakan tentang gerakan janin dalam 24 jam terakhir

b. Mendapatkan informasi tentang setiap masalah atau tanda bahaya yang mungkin dialami klien sejak kunjungan terakhirnya

c. Mendapatkan informasi tentang keluhan-keluhan lazim/yang biasa dialmai ibu hamil

d. Menanyakan apakah klien mempunyai pertanyaan atau kekhawatiran lain yang timbul sejak kunjungan terakhirnya 
e. Menanyakan bagaimana perasaan klien sejak kunjungan terakhirnya

f. Mendapatkan riwayat kehamilan ibu dan mendengarkan dengan teliti apa yang diceritakan ibu

g. Selama pengambilan riwayat, bidan tetap membina hubungan saling percaya dengan ibu dan keluarga

2. Pemeriksaan fisik

a. Berat badan

b. Tekanan darah

c. Pemeriksaan tekanan darah

d. Mengukur tinggi fundus uteri dengan tang (>12 minggu) atau dengan pita ukur (>22 minggu).

e. Melakukan palpasi abdomen untuk mendeteksi adanya kehamilan ganda (jka >28 minggu)

f. Maneuver Leopold untuk mendeteksi kelainan letak,presentasi posisi,da penurunan kepala janin (setelah >36 minggu)

g. Mengukur DJJ (dengan fetoskop kalau <18 minggu)

h. Melakukan pemeriksaan fisik seperlunya saja.

3. Pemeriksaan laboratorium

Pemeriksaan proteinuria

Hasil penelitian menunjukkan bahwa penapisan rutin proteinuria merupakan cara efektif dalam mendeteksi preeklamsia, suatu keadaan yang membayakan jiwa.

4. Pemberian suplemen,imunisasi dan konseling

a. Memberikan zat besi 90 tablet mulai minggu ke-20 
b. Memberikan imunisasi TT 0,5 cc jika sebelumnya telah mendapatkannya

c. Gizi : peningkatan konsumsi makanan hingga 300 kalori per hari, mengonsumsi bahan makanan yang mengandung protein,zat besi,minuman cukup cairan (menu seimbang)

d. Perubahan fisiologis tambah berat badan perubahan pada payudara, tingkat tenaga yang menurun rasa panas,varises,hubungan suami istri boleh dilanjutkan selama kehamilan (dianjurkan memakai kondom)

e. Menjelaskan pada ibu mengenai ketidaknyaman normal yang dialaminya

f. Menanyakan pada ibu mengenai status nutrisi,suplemen zat besi dan tetanus toxoid

g. Sesuai dengan usia kehamilan,ajarkanlah ibu mengenai pemberian ASI termasuk didalamnya menjelaskan cara perawatan payudara terutama bagi ibu yang mempunyai putting susu yang rata/masuk kedalam dilakukan dua kali sehari selama 5 menit, latihan (exercise) olahraga ringan,istirahat dan pertumbuhan janin.

h. Menjaga kebersihan diri terutama lipatan kulit (ketiak bawah buah dada,daerah genitalia) dengan cara dibersihkan dengan air dan dikeringkan.

i. Mendiskusikan rencana persiapan kelahiran?kegawatdaruratan

j. Mengajari ibu jika mengenai tanda bahaya pastikan ibu memahami apa yang dilakukan jika menemukan tanda bahaya diantaranya seperti :

- Perdarahan pervaginam 
- Sakit kepala lebih dari biasanya

- Gangguan penglihatan

- Pembengkakan pada wajah / tangan

- Nyeri abdomen (epigastrik)

- Janin tidak bergerak sebanyak biasanya.

k. Petunjuk dini untuk mencegah keterlambatan dalam mengambil keputusan dan upaya rujukan saat terjadi komplikasi. Nasihat ibu hamil, suaminya,ibu atau anggota keluarga lainnya untuk mengidentifikasi sumber transportasi serta menyisihkan cukup dana untuk menutup biaya perawatan kegawatdaruratan.

1. Jadwalkan kunjungan ulang berikutnya.

5. Pendokumentasian

Mendokumentasikan hasil kunjungan pada catatan SOAP dan mendokumentasikan hasil pemeriksaan dalam kartu/buku ibu hamil.

\section{Jadwal Kunjungan Ulang}

1. Kunjungan I (16 minggu 0 bertujuan untuk hal-hal berikut ini :

a. Penapisan dan pengobatan anemia

b. Perencanaan persalinan

c. Pencegahan komplikasi akibat kehamilan dan pengobatan

2. Kunjungan II (24-28 minggu) dana kunjungan III (32 minggu ) bertujuan untuk hal-hal berikut ini :

a. Pengenalan komplikasi akibat kehamilan dan pengobatannya

b. Penapisan preeklamsia,gemeli,infeksi alat reproduksi dan saluran perkemihan

c. Mengulang perencanaan persalinan

3. Kunjungan IV (36 minggu) sampai lahir 

a. Sama seperti kunjungan II dan III
b. Mengenali adanya kelainan letak dan presentasi
c. Memantau rencana persalinan
d. Mengenali tanda-tanda persalinan. 


\section{BAB VII}

\section{DETEKSI DINI TERHADAP KOMPLIKASI IBU DAN JANIN}

\section{A. Pendahuluan}

\section{Deskripsi Singkat}

Mata kuliah ini akan membahas tentang tanda-tanda dini bahaya/komplikasi ibu dan janin masa kehamilan muda dan kehamilan lanjut.

2. Tujuan Instruksional Khusus

Diharapkan setelah mengikuti mata kuliah ini mahasiswa mampu mengenali secara dini bahaya/komplikasi ibu dan janin.

\section{B. Tanda-Tanda Dini Bahaya/Komplikasi Ibu Dan Janin Masa Kehamilan Muda}

1. Perdarahan Pervaginam

a. Abortus Imminens

1) Tanda dan gejala : perdarahan vagina: merah segar atau coklat, jumlah perdarahan sedikit, dapat terjadi terus menerus untuk beberapa hari sampai 2 minggu, kram abdomen bagian bawah atau sakit punggung normal

2) Manajemen

Trimester I dengan sedikit perdarahan, tanpa disertai kram.

a) Tirah baring tidak terlalu bermanfaat; aktivitas normal dapat dilanjutkan kembali kecuali wanita merasa tidak nyaman atau lebih memilih untuk istirahat.

b) Istirahatkan panggul (tidak berhubungan seksual, tidak melakukan irigasi, atau memasukkan sesuatu ke vagina). 
c) Tidak melakukan aktivitas seksual yang menimbulkan orgasme

d) Segera beritahu bidan jika terdapat :

Perdarahan meningkat

Kram dan nyeri pinggang meningkat

Semburan cairan dari vagina

Demam atau gejala mirip flu

e) Periksakan pada hari berikutnya di rumah sakit

f) Evaluasi tanda-tanda vital

g) Pemeriksaan dengan speculum-merupakan skrining vaginitis dan servisitis; observasi bukaan serviks, tonjolan kantong ketuban, bekuan darah, atau bagian-bagian janin

h) Pemeriksaan bimanual-ukuranuterus, dilatasi, nyeri tekan, effacement, serta kondisi ketuban. Dapatkan nilai hemoglobin dan hematokrit, jenis dan Rh (jika belum ada)

i) Jika pemeriksaan negative, dapat dilakukan pemeriksaan ultrasuara untuk menentukan kelangsungan hidup janin, tanggal kelahiran, dan jika mungkin untuk menenangkan wanita. Jika pemeriksaan fisik dan ultrasuara negatif, tenangkan wanita, kaji ulang gejala bahaya dan pertahankan nilai normal

j) Konsultasi ke dokter jika terjadi perdarahan hebat, kram meningkat, atau hasil pemeriksaan fisik dan ultrasuara menunjukan hasil abnormal

b. Abortus Insipiens

1) Pengertian 
Keguguran membakat ini tidak dapat dihentikan, karena setiap saat dapat terjadi ancaman perdarahan dan pengeluaran hasil konsepsi.

2) Tanda dan gejala

a) Perdarahan lebih banyak

b)Perut mules (sakit) lebih hebat

c) Pada pemeriksaan dijumpai perdarahan lebih banyak, kanalis servikalis terbuka dan jaringan/hasil konsepsi dapat teraba

3) Penanganan

Jika usia kehamilan kurang dari 16 minggu

a)Lakukan evakuasi uterus dengan Aspirasi Vakum Manual (AVM). Jika evakuasi tidak dapat segera dilakukan:

b)Berikan ergometrin 0,2 mg I.M (dapat diulang sesudah 15 menit jika perlu) atau misoprostol $400 \mathrm{mcg}$ per oral (dapat diulang sesudah 4 jam jika perlu)

c) Segera lakukan persiapan untuk pengeluaran hasil konsepsi dari uterus.

Jika usia kehamilan lebih dari 16 minggu

a) Tunggu ekspulsi spontan hasil konsepsi, kemudian evakuasi sisa-sisa hasil konsepsi

b)Jika perlu, lakukan infus 20 unit oksitosin dalam $500 \mathrm{ml}$ cairan I.V (garam fisiologik atau larutan Ringer Laktat) dengan kecepatan 40 tetes per menit untuk membantu ekspulsi hasil konsepsi 
c) Pastikan untuk tetap memantau kondisi ibu setelah penanganan

c. Abortus Inkomplit

1) Pengertian

Ditandai dengan dikeluarkannya sebagian hasil konsepsi dari uterus.

2) Gejala klinis

a) Perdarahan berlangsung terus

b)Perdarahan mendadak

c) Disertai infeksi dengan suhu tinggi

d)Dapat terjadi degenerasi ganas (korio karsinoma)

e) Pada pemeriksaan dijumpai gambaran: Kanalis servikalis terbuka, Dapat diraba jaringan dalam rahim atau dikanalis servikalis, Kanalis servikalis tertutup dan perdarahan berlangsung terus, Dengan pemeriksaan sonde perdarahan bertambah

3) Penanganan

a) Jika perdarahan tidak terlalu banyak dan kehamilan kurang dari 16 minggu, evakuasi dapat dilakukan secara digital atau dengan cunam ovum untuk mengeluarkan hasil konsepsi yang keluar melalui serviks. Jika perdarahan berhenti, beri ergometrin 0,2 mg I.M atau misoprostol 400 mcg per oral

b)Jika perdarahan banyak atau terus berlangsung dan usia kehamilan kurang dari 16 minggu, evakuasi sisa hasil konsepsi dengan: Aspirasi Vakum Manual (AVM), kuret 
tajam sebaiknya hanya dilakukan jika aspirasi vakum manual tidak tersedia.

c) Jika evakuasi belum dapat dilakukan segera, beri ergometrin 0,2 mg I.M (diulangi setelah 15 menit jika perlu) atau misoprostol $400 \mathrm{mcg}$ per oral (dapat diulangi setelah 4 jam jika perlu).

d)Jika kehamilan lebih dari 16 minggu: Berikan infus oksitosin 20 unit dalam $500 \mathrm{ml}$ cairan I.V (garam fisiologik atau Ringer Laktat) dengan kecepatan 40 tetes/menit sampai terjadi ekspulsi hasil konsepsi. Jika perlu berikan misoprostol 200 mcg pervaginam setiap 4 jam sampai terjadi ekspulsi hasil konsepsi (maksimal $800 \mathrm{mcg}$ ). Evakuasi sisa hasil konsepsi yang tertinggal dalam uterus. Pastikan untuk tetap memantau kondisi ibu setelah penanganan.

d. Abortus Komplit

1) Pengertian

Seluruh hasil konsepsi telah dikeluarkan, sehingga tidak memerlukan tindakan. Gambaran klinisnya adalah uterus mengecil, perdarahan sedikit, dan kanalis telah tertutup.

2) Penanganan:

a) Tidak perlu evakuasi lagi

b)Observasi untuk melihat adanya perdarahan banyak

c) Pastikan untuk tetap memantau kondisi ibu setelah penanganan 
d)Apabila terdapat anemia sedang, berikan tablet sulfas ferrosus $600 \mathrm{mg} / \mathrm{hari}$ selama $2 \mathrm{minggu}$, jika anemia berat berikan transfusi darah

e) Konseling asuhan pascakeguguran dan pemantauan lanjut

e. Mola Hidatidosa

1) Pengertian

Adalah jonjot-jonjot korion yang tumbuh berganda berupa gelembung-gelembung kecil yang mengandung banyak cairan sehingga menyerupai buah anggur, atau mata ikan. Kehamilan mola merupakan proliferasi abnormal dari vili khorialis.

2) Etiologi

Penyebab mola belum diketahui dengan pasti, faktor-faktor yang dapat menyebabkannya antara lain:

a)Faktor ovum, ovum memang sudah patologik sehingga mati, tetapi terlambat dikeluarkan.

b)Imunoselektif dari trofoblas

c) Keadaan sosek rendah

d)Paritas tinggi

e) Kekurangan protein

f) Infeksi virus dan faktor kromosom yang belum jelas

3) Diagnosis dan gejala

Anamnesa/keluhan:

a)Terdapat gejal-gejala hamil muda yang kadang-kadang lebih nyata dari kehamilan biasa Kadangkala ada tanda toksemia gravidarum 
b)Terdapat perdarahan yang sedikit atau banyak, tidak teratur, warna tengguli tua atau kecoklatan seperti bumbu rujak

c) Pembesaran uterus tidak sesuai (lebih besar) dengan tua kehamilan seharusnya

d)Keluar janringan mola seperti buah anggur atau mata ikan yang merupakan diagnosa pasti.

e) Inspeksi : Muka dan kadang-kadang badan kelihatan pucat kekuning-kuningan (mola face). Bila gelembung mola keluar akan terlihat dengan jelas.

f) Palpasi : Uterus membesar tidak sesuai dengan tuanya kehamilan, teraba lembek. Tidak teraba bagian-bagian janin dan balotemen, juga gerakan janin. Adanya fenomena harmonica; darah dan gelembung mola keluar, dan fundus uteri turun: lalu naik lagi karena terkumpulnya darah baru

g)Auskultasi : Tidak terdengar bunyi denyut jantung janin, Terdengar bising dan bunyi khas. Reaksi Kehamilan, karena kadar HCG yang tinggi maka uji biologic dan uji imunologik (Galli Mainini dan planotest) akan positif setelah pengenceran (titrasi) :

h)Galli Mainini 1/300 (+), maka suspek mola hidatidosa

Galli Mainini 1/200 (+), maka kemungkinan mola hidatidosa atau hamil kembar. Bahkan pada mola atau koriokarsinoma, uji biologik atau imunologik cairan serebro-spinal dapat menjadi positif.

i) Pemeriksaan dalam 
Pastikan besarnya rahim, rahim terasa lembek, tidak ada bagian-bagian janin, terdapat perdarahan dan jaringan dalam kanalis servikalis dan vagina, serta evaluasi keadaan serviks.

Uji sonde, sonde dimasukkan pelan-pelan dan hati-hati ke dalam kanalis servikalis dan kavum uteri, bila tidak ada tahanan, sonde diputar setelah ditarik sedikit, bila tetap tidak ada tahanan, kemungkinan mola.

Foto rontgen abdomen, tidak terlihat tulang-tulang janin (pada kehamilan 3-4 bulan).

Arteriogram khusus pelvis

Ultrasonografi, pada mola akan kelihatan bayangan badai salju dan tidak terlihat janin.

4) Penanganan awal:

Jika diagnosis kehamilan mola telah ditegakkan, lakukan evakuasi uterus:

Segera lakukan evakuasi jaringan mola dan sementara proses evakuasi berlangsung berikan infus 10 unit oksitosin dalam $500 \mathrm{ml}$ cairan I.V ( $\mathrm{NaCl}$ atau Ringer Laktat) dengan kecepatan 40-60 tetes per menit (sebagai tindakan preventif terhadap perdarahan hebat dan efektifitas kontraksi terhadap pengosongan uterus secara cepat)

5) Penanganan selanjutnya:

Pasien dianjurkan untuk menggunakan kontrasepsi hormonal atau tubektomi bila ingin menghentikan fertilitas. Lakukan pemantauan setiap 8 minggu selama minimal 1 tahun pasca 
evakuasi dengan menggunakan tes kehamilan dengan urin karena adanya risiko timbulnya penyakit trofoblas yang menetap atau khoriokarsinoma. Jika tes kehamilan dengan urin tidak negatif setelah 8 minggu atau menjadi positif kembali dalam 1 tahun pertama, rujuk ke pusat kesehatan tersier untuk pemantaun dan penanganan lebih lanjut.

f. Kehamilan Ektopik

1) Pengertian

Perjalanan hasil konsepsi dapat terganggu dalam perjalanan sehingga tersangkut dalam lumen tuba. Tuba falopii tidak mempunyai kemampuan untuk berkembang dan menampung pertumbuhan janin sehingga setiap saat kehamilan yang terjadi terancam pecah.

Kehamilan ektopik adalah kehamilan dengan implantasi terjadi di luar rongga uterus. Tuba falopii merupakan tempat tersering untuk terjadinya implantasi kehamilan ektopik (lebih besar dari 90\%).

2) Diagnosis banding

a) Abortus iminens

b)Penyakit radang panggul baik akut maupun kronis

c) Kista ovarium (terpuntir atau ruptur) dan apendisitis akut

3) Tanda dan gejala kehamilan ektopik

Tanda dan gejalanya sangatlah bervariasi bergantung pada pecah atau tidaknya kehamilan tersebut. Alat penting yang dapat digunakan untuk mendiagnosis kehamilan ektopik yang pecah adalah tes kehamilan dari serum dikombinasi dengan 
ultrasonografi. Jika diperoleh hasil darah yang tidak membeku, segera mulai penanganan.

2. Hipertensi Dalam Kehamilan

Terdapat tiga kategori besar kelainan hipertensi yang disebabkan oleh kehamilan pregnancy induced hypertension. Klasifikasi umum kelainan hipertensi sebagai komplikasi adalah sebagai berikut :

\section{a. Pregnancy - Induced Hypertension}

1) Hanya hipertensi tanpa disertai proteinuria atau edema patologik (beberapa kepustakaan menyebutkan sebagai transient hypertension, peningkatan tekanan darah selama kehamilan atau 24 jam pertama pascapersalinan tanpa adanya komplikasi lainnya).

2) Preeklamsia-hipertensi disertai proteinuria dan/atau edema patologik biasanya terjadi setelah minggu ke-20 (atau lebih awal pada adanya kasus penyakit trofoblast seperti mola atau hidrops). Terbagi atas preeklamsia ringan dan berat.

3) Eklamsia-hipertensi disertai proteinuria dan/atau edema patologik dan konvulsi/kejang dan atau koma. Preeklamsia/eklamsia sering disebut juga toxemia gravidarum.

\section{b. Pregnancy-aggravated Hypertension}

Hipertensi yang telah ada diluar kehamilan yang diperberat dengan adanya kehamilan.

1) Superimposed preeklamsia

2) Superimposed eklamsia

\section{c. Coincidental Hypertension}


Penelitian berbagai factor risiko terhadap hipertensi pada kehamilan/preeklamsia/eklamsia menghasilkan hal-hal sebagai berikut :

1) Usia

Insiden tinggi pada primigravida muda, meningkat pada primigravida tua. Pada wanita berusia kurang dari 25 tahun insiden > 3 kali lipat. Pada wanita hamil berusia dari 35 tahun dapat terjadi hipertensi laten

2) Paritas

a. Angka kejadian tinggi pada primigravida,muda maupun tua b. Primigravida tua risiko lebih tinggi untuk preeklamsia berat

3) Ras/golongan etnik

Bias (mungkin ada perbedaan perlakuan/akses terhadap berbagai etnik di banyak Negara)

4) Factor keturunan

Jika ada riwayat preeklamsia/eklamsia pada ibu/nenek penderita,factor risiko meningkat sampai $\pm 25 \%$

5) Factor gen

Diduga adanya suatu sifat resesif yang ditentukan oleh genotip ibu dan janin

6) Diet/gizi

Tidak ada hubungan bermakna antara diet tertentu (WHO). Penelitian lain menyebutkan bahwa kalsium berhubungan dengan angka kejadian yang tinggi. Angka kejadian lebih tinggi pada ibu hamil yang obesitas

7) Iklim/musim 
Didaerah tropis insiden lebih tinggi

8) Tingkah laku/sosioekonomi

Kebiasaan merokok : insiden pada ibu perokok lebih rendah,namun merokok selama hamil memiliki risiko kematian janin dan pertumbuhan janin terhambat yang jauh lebih tinggi. Aktivitas fisik selama hamil sitarahat baring yang cukup selama hamil mengurangi kemungkinan/insiden hipertensi dalam kehamilan.

9) Hiperplasentosis

Proteinuria dan hipertensi gravidarum lebih tinggi kemungkinnya pada kehamilan kembar, dizigotik lebih tinggi daripada monozigot. Hidropes fetalis berhubungan mencapai sekitar $50 \%$ kasus.

Diabetes mellitus : angka kejadian yang ada kemungkinan patofisiologinya bukan preklamsia murni, melainkan disertai kelainan ginjal/vascular primer akibat diabetesnya.

Molahidatidosa : diduga akibat trofoblast berlebihan berperan menyebabkan preeklamsia. Pada kasus mola, hipertensi dan proteinuria terjadi lebih dini /pada usia kehamilan muda, ternyata hasil pemeriksaan patologi ginjal juga sesuai dengan pada preeklamsia.

\section{d. Patofisiologi Preeklamsia}

Sampai sekarang etiologi preeklamsia belum diketahui. Membicarakan patofisiologinya tidak lebih dari mengumpulkan temuan-temuan fenomena yang beragam. Namun pengetahuan tentang temuan yang beragam inilah kunci utama suksesnya 
penanganan preeklamsia sehingga preeklamsia/eklamsia disebut seagai the disease of many theories in obstetrics.

1) Perubahan Kardiovaskuler

a) Turunnya tekanan darah pada kehamilan normal dikarenakan vasodilatasi perifer. Vasodilatasi perifer terjadi karena adanya penurunan tonus otot polos arterial akibat meningkatnya kadar progesterone dalam sirkulasi.

b) Menurunnya kadar vasokontriksi (adrenail/ noradrenalin/ angiotensin II).

c) Menurunnya respons dinding vascular terhadap vasokontriktor akibat produksi vasodilatator/prostanoid yang juga tinggi (PGE2/PGI2).

d) Menurunnya aktivitas susunan saraf simpatis vasomotor. Pada trimester ke tiga akan terjadi peningkatan tekanan darah yang normal ke takanan darah sebelum hamil.

e) Setikar 1/3 pasien preeklamsia terjadi pembalikan ritme diurnal dan tekanan darah naik pada malam hari. Selain itu,juga terdapat perubahan lama siklus diurnal menjadi 20 jam perhari, dengan penurunan selama tidur, yang mungkin disebabkan perubahan di pusat pengatur tekanan darah atau pada reflex baroreseptor.

2) Regulasi Volume Darah

Pengendalian garam dan homeostatis juga meningkat pada preeklamsia. Kemampuan mengeluarkan natrium terganggu, tetapi derajatnya bervariasi. Pada keadaan berat mungkin juga tidak ditemukan edema (suatu preeklamsia 
kering). Jika ada edema interstiasial volume plasma lebih rendah dibandingkan wanita hamil normal, dan dengan demikian terjadi hemokonsentrasi. Porsi curah jantung untuk perfusi perifer relative turun.

Perfusi plasenta melakukan adaptasi terhadap perubahanperubahan ini,maka pemakaian diuretic adalah tidak sesuai karean justru akan memperburuk hipovolemia. Plasenta juga menghasilkan renin, diduga berfungsi cadangan untuk mengatur tonus dan permeabilitas vascular local demi mempertahankan sirkulasi fetomaternal. Perubahan metabolism steroid tidak jelas. Kadar aldosterone turun,kadar progesterone tidak berubah.

Kelainan fungsi pembekuan darah ditunjukkan dengan penurunan AT III. Rata-rata volume darah pada penderita preeklamsia lebih rendah sampai $500 \mathrm{ml}$ disbanding wanita hamil normal.

3) Fungsi Organ -organ Lain :

\section{a) Otak}

Pada hamil normal, perfusi serebri tidak berubah, namun pada preeklamsia terjadi spasme pembuluh darah otak dan penurunan perfusi dan suplai oksigen otak sampai $20 \%$. Spasme dapat menyebabkan hipertensi serebral yang merupakan factor penting terjadinya perdarahan otak dan kejang/eklamsia. 
b) Hati

Terjadi peningkatan aktivitas enzim-enzim hati pada preeklamsia yang berhubungan dengan beratnya penyakit

c) Ginjal

Pada preeklamsia arus darah efektif ginjal berkurang \pm $20 \%$,filtrasi glomerulus berkurang $\pm 30 \%$. Pada kasus berat terjadi oliguria,uremia sampai nekrosis tubular akut dan nekrosis korteks renalis. Ureum-kreatinin meningkat jauh di atas normal. Terjadi juga peningkatan pengeluaran protein(syndrome nefrotik pada kehamilan).

4) Sirkulasi Uterus, Koriodesidua dan Plasenta

Perubahan araus darah di uterus,koriodesidua dan plasenta adalah patofisiologi yang terpenting pada preeklamsia. Hal ini merupakan factor yang menentukan hasil akhir kehamilan.

a) Terjadinya iskemia uteroplasenter menyebabkan ketidakseimbangan antara massa plasenta yang meningkat dengan aliran perfusi darah sirkulasi yang berkurang.

b) Hipoperfusi uterus menjadi rangsangan produksi renin di uteroplasenter yang mengakibatkan vasokontriksi vaskuler daerah itu. Renin juga meningkatkan kepekaan vascular terhadap zat-zat vasokontriksi lain (angiotensin,aldosterone) sehingga terjadi tonus pembuluh darah yang lebih tinggi.

c) Oleh karena gangguan sirkulasi uteroplasenter ini terjadi penurunan suplai oksigen dan nutrisi ke janin. Akibtanya 
bervariasi dari gangguan pertumbuhan janin sampai hipoksia dan kematian janin.

\section{e. Diagnosis Preeklamsia}

Diagnosis preeklamsia ditegakkan berdasarkan hal-hal berikut ini :

1. Penigkatan tekanan daraha yang lebih besar atau sama dengan 140/90 mmHg

2. Peningkatan tekanan sistolik $? 30 \mathrm{mmHg}$ atau diastolic $>15$ $\mathrm{mmHg}$

3. Peningkatan mean arterial pressure (MAP) $>20 \mathrm{mmHg}$ atau $>105$ MMhg

4. Proteinuria signifikan, $300 \mathrm{mg} / 24$ jam atau $>1 \mathrm{~g} / \mathrm{ml}$

5. Diukur pada dua kali pemeriksaan dengan jarak waktu 6 jam

6. Edema umum atau peningkatan berat badan berlebihan

7. Tekanan darah di ukur setelah pasien istrahat 30 menit (ideal). Tekanan darah sistolik adalah saat terdengar bunyi Koroktoff I,tekanan darah diastolic pada Koroktkoff IV.

\section{f. Kriteria Diagnostik Preeklamsia Berat}

1. Tekanan darah sistolik $>160 \mathrm{mmHg}$ atau diastolic $>110$ mmHG

2. Proteinuria $=5$ atau $(3+)$ pada tes celup strip

3. Oliguria,diuresis $<400 \mathrm{ml}$ dalam 24 jam

4. Sakit kepala hebat dan gangguan penglihatan

5. Nyeri epigastrium atau kuadran kanan atas abdomen atau ada icterus

6. Edema paru atau sianosis 
7. Trombositopenia

8. Pertumbuhan janin terhambat

\section{g. Penatalaksanaan Preeklamsia}

Prinsip penatalaksanaan preeklamsia adalah sebagai berikut

1. Melindungi ibu dari efek peningkatan tekanan darah

2. Mencegah progresivitas penyakit menjadi eklamsia

3. Mengatasi atau menurunkan risiko janin (solusio plasenta,pertumbuhan janin terhambat,hipoksia sampai kematian janin)

4. Melahirkan janin dengan cara yang paling aman dan cepat sesegara mungkin setelah matur atau imatur jika diketahui bahwa risiko janin atau ibu akan lebih berat jika persalinan di tunda lebih lama.

Penatalaksanaan preeklamsia ringan adalah sebagai berikut :

1. Dapat dikatakan tidak mempunyai risiko bagi ibu maupun janin

2. Tidak perlu segera diberikan obat antihipertensi atau obat lainnya, tidak perlu dirawat kecuali tekanan darah meningkat terus (batas aman 140-150/90-100 $\mathrm{mmHg}$ )

3. Istirahat yang cukup (berbaring/tirah baring minimal 4 jam pada siang hari dan minimal 8 jam pada malam hari ).

4. Pemberian luminal 1-2 × $30 \mathrm{mg} /$ hari bila tidak bisa tidur

5. Pemberian asam asetilsalisilat (aspirin) 1x80 mg/hari.

6. Bila tekanan darah tidak turun, dianjurkan dirawat dan diberi obat antihipertensi metildopa 3x $125 \mathrm{mg} / \mathrm{hari}$ (maksimal $1500 \mathrm{mg} / \mathrm{hari})$ atau nifedipin $3-8 \quad \mathrm{x}-5-10 \mathrm{mg} / \mathrm{hari}$, atau 
nifedipin retard 2-3 x $20 \mathrm{mg} / \mathrm{hari}$, atau pindolol 1-3 $\mathrm{mg} / \mathrm{hari}$ (maksimal $30 \mathrm{mg} /$ hari).

7. Tidak perlu diet rendah garam dan diuretic

8. Jika maturitas janin masis lama, lanjutkan kehamilan dan periksa tiap 1 minggu

9. Indikasi rawat jika ada perburukan, tekanan darah dan tidak turun setelah 2 minggu rawat jalan, peningkatan berat badan melebihi $1 \mathrm{~kg} /$ minggu 2 kali bertururt-turut atau pasien menunjukkan tanda-tanda preeklamsia berat. Berikan juga obat antihipertensi.

10.Jika dalam perawatan tidak ada perbaikan, lakukan tatalaksana sebagai preeklamsia berat. Jika ada perbaikan lakukan rawat jalan.

11.Pengakhiran kehamilan : dirunggu sampai usia 40 minggu kecuali ditemukan pertumbuhan janin terhambat, gawat janin, solusio palsenta eklamsia atau indikasi terminasi lainnya. Minimal usia 38 minggu, janin sudah dinayatakn matur

12.Persalinan pada preeklamsia ringan dapat dilakukan spontan atau dengan bantuan ekstraksi untuk mempercepat kala II.

\section{Nyeri Perut Bagian Bawah}

Nyeri perut pada kehamilan 22 minggu atau kurang. Hal ini mungkin gejala utama kehamilan ektopik atau abortus.

a. Kista Ovarium

Anamnesa : nyeri perut dan perdarahan ringan

Pemeriksaan Fisik : teraba massa Tumor

b. Apendisistis 
Anamnesa : nyeri perut bagian bawah, demam, nyeri lepas, mual muntah dan anoreksia

Pemeriksaan Fisik : Perut membengkak dan nyeri di atas Mcburney

c. Sistisis

Anamnesa : dysuria, Sering berkemih, Nyeri perut

Pemeriksaan fisik : nyeri retro/suprapubik

d. Pielonefritis akut

Anamnesa ; dysuria, Demam tinggi/menggigil/ sering miksi dan nyeri perut

Deteksi dini dalam pelayanan antenatal adalaha untuk mengarah pada penemuan ibu hamil beresiko agar dapat ditangani secara memadai sehingga kesakitan atau kematoan dapat dicegah. Untuk pengenalan tanda-tanda kehamilan yang memiliki tanda bahaya dan komplikasi kehamilan banyak poster dan leaflet disebarkan kepada masyarakat khususnya ibu-ibu hamil yang berkunjung dalam pelayanan antenatal maupun pada kegiatan kunjungan rumah dalam pemantauan kesehatan masyarakat.

Deteksi dini resiko kehamilan adalah usaha menemukan seawall mungkin adaanya kelainan, komplikasi dan penyulit kehamilan serta menyiapkan ibu untuk persalinan normal.

\section{Tanda-Tanda Bahaya pada Kehamilan Lanjut}

Perdarahan antepartum dibatasi pada perdarahan dari jalan lahir setelah usia kehamilan 22 minggu (meskipun psikologi yang sama dapat juga terjadi pada kehamilan selama 22 minggu ). Batasan waktu menurut kepustakaan lain bervariasi, ada yang mengtakan 24-28 
minggu (trimester ketiga). Perdarahan yang berbahaya karena cepat dan banyak yaitu perdarahan yang berasal dari kelainan/gangguan pada plasenta. Perdarahan yang bukan dari plasenta (misalnya serviks), relative lebih tidak berbahaya. Diagnosis banding yang dipakai adalah perdarahan karena sebab obstetric atau bukan karena sebab obstetric .

Klasifikasi etiologi perdarahan pada Trimester III

\begin{tabular}{|c|c|c|}
\hline \multirow{2}{*}{ Risiko } & \multicolumn{2}{|l|}{ Penyebab } \\
\hline & Obstetric & Non obstetri \\
\hline Tinggi & $\begin{array}{l}\text { Plasenta Previa } \\
\text { Abruption plasenta } \\
\text { Vasa previa dengan perdarahan } \\
\text { fetal }\end{array}$ & 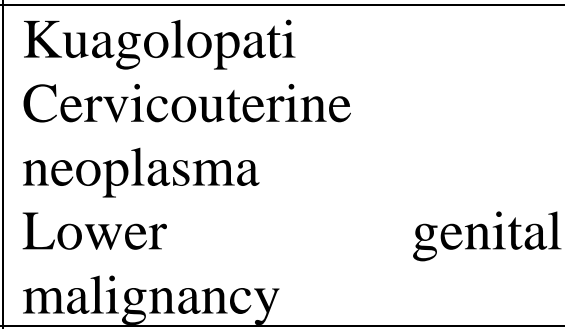 \\
\hline Sedang & $\begin{array}{l}\text { Circumvalatte plasenta } \\
\text { Marginal sinus rupture }\end{array}$ & $\begin{array}{l}\text { Varises vagina } \\
\text { Laserasi vagina }\end{array}$ \\
\hline Rendah & $\begin{array}{l}\text { Cervical mucous extrusion (the } \\
\text { bloodyshow) }\end{array}$ & $\begin{array}{l}\text { Cervicitis } \\
\text { Eversion,erosion polyps }\end{array}$ \\
\hline
\end{tabular}

\section{Plasenta Previa}

Plasenta previa adalah keadaan letak plasenta yang abnormal yaitu pada segmen bawah uterus sehingga dapat menutupi sebagain atau seluruh jalan lahir (pada keadaan normal,plasenta terletak dibagian fundus atau segmen atas uterus).

Plasenta previa terbagai atas hal-hal berikut :

a. Plasenta previa totalis : jika seluruh pembukaan jalan lahir tertutup jaringan plasenta

b. Plasenta previa parsialis : jika sebagain pembukaan jalan lahir tertutup jaringan plasenta

c. Plasenta previa marginalis : jika tepi plasenta berada tepat pada tepi pembukaan jalan lahir 
d. Plasenta letak rendah : jika plasenta terletak pada segmen bawah uterus tetapi tidak sampai menutupi permukaan jalan lahir.

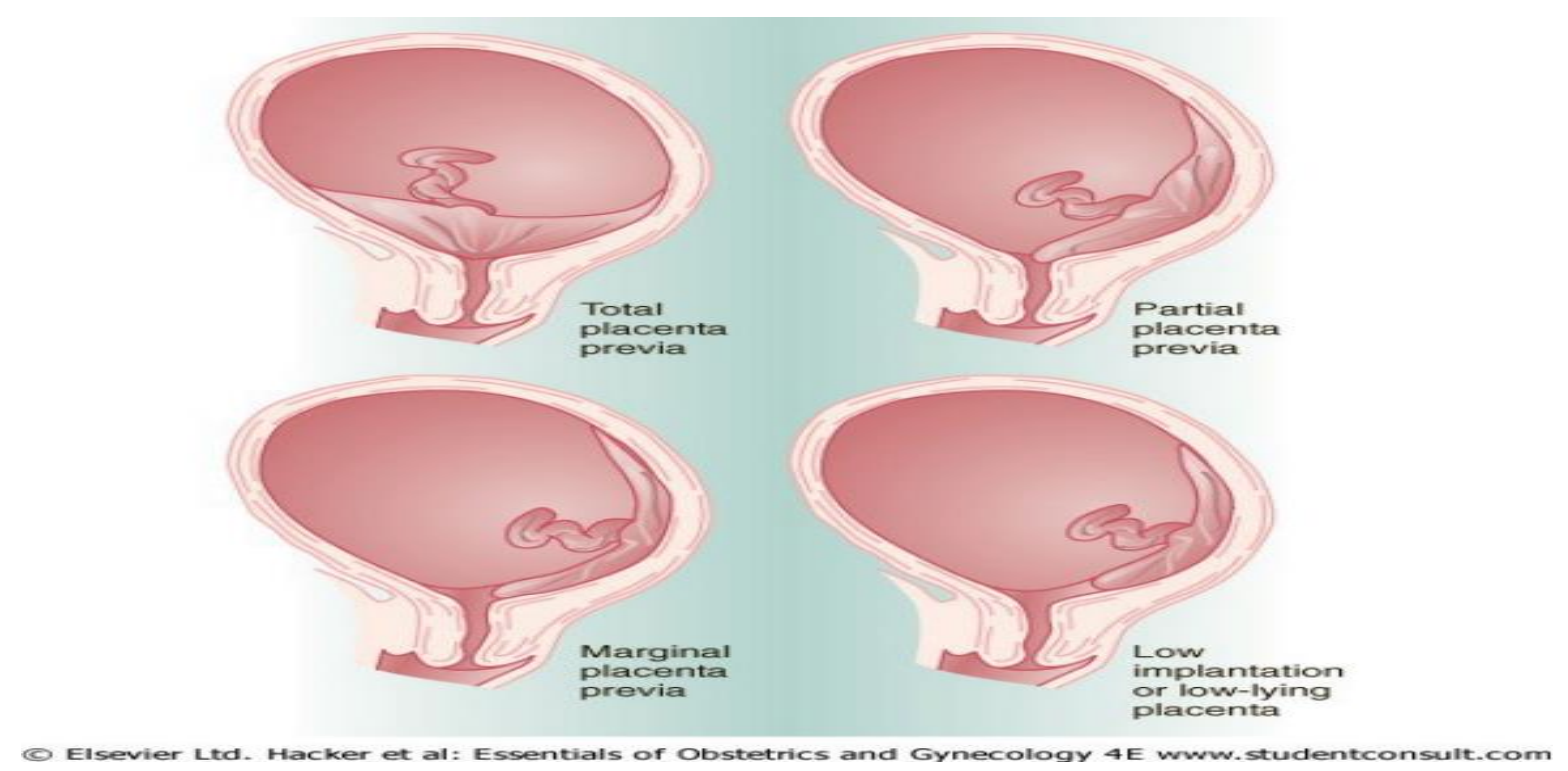

\section{Etiologi}

Belum ada etiologi jelas yang dapat menjelaskan penyebab dari terjadinya plasenta previa. Diperkirakan karena adanya gangguan distribusi vaskularisasi uterus atau atrofi desidua, misalnya akibat perdarahan persalinan sebelumnya. Jika ada massa tumor di korpus/segmen atau uterus (misalnya mioma), kemungkinan plasenta juga akan berimplantasi di bawah,tetapi belum jelas hubungannya.

Tanda dan gejala dari plasenta previa adalah sebagai berikut :

a. Perdarahan terbawah janin belum masuk panggul

b. Adanya kelainan letak janin

c. Bagian terbawah janin belum masuk panggul

d. Tidak disertai gejala nyeri (tanda khas plasenta previa )

e. Pada pemeriksaan jalan lahir teraba jaringan plasenta (lunak) 
f. Dapat disertai gawat janin sampai kematian janin tergantung beratnya.

\section{Diagnosis}

Anamneses : riwayat perdarahan, tidak nyeri, darah merah segar Pemeriksaan obstetric: keadaan umum/tanda vital ibu mungkin dapat baik sampai buruk,tergantung beratnya perdarahan Pemeriksaan obstetric : bagian terbawah janin biasanya belum masuk pintu atas panggul. Inspekulo tampak dara dari ostium Pemeriksaan penunjang : konfirmasi USG jika mungkin

\section{Penatalaksanaan}

a. Penatalaksanaan pasif. Pada perdarahan PERTAMA, prinsipnya, jika usia kehamilan belum optimal, kehamilan masih dapat dipertahankan karena perdarahan pertama umumnya tidak berat dan dapat berhenti dengan sendirinya. Pasien harus dirawat dengan istirahat baring total di rumah sakit, dengan persiapan transfuse darah dan operasi sewaktu-waktu. Akan tetapi jika pada perdarahan pertama itu telah dilakukan pemeriksaan dalam/vaginal touch, kemungkinan besar akan terjadi perdarahan yang lebih berat sehingga harus diterminasi.

b. Pilihan persalinan : tergantung dari letak/derajat plasenta previa, kemudian umum ibu dan keadaan janin. Pada plasenta previa totalis/parsialis sebaiknya dilakukan SC. Pada perdarahan yang berat dengan keadaan ibu dan janin yang buruk, juga harus dilakukan SC segera. 
c. Jika persalinan yang dipilih adalah pervaginam, misalnya pada kasus plasenta previa marginalis atau plasenta letak rendah, dilakukan pemecahan selaput ketuban (amniotomi). Diharapkan penurunan janin akan dapat menekan plasenta dan menghentikan perdarahan. Akan tetapi penekanan terhadap plasent juga berarti supresi terhadap sirkulasi feto-maternal, yang jika berlangsung lama dapat menyebabkan kematian janin. Tampaknya SC tetap menjadi alternative terbaik. Persalinan pervaginam hanya dilakukan pada keadaan dimana SC tidak mungkin dilakukan tetapi dengan pemahaman bahwa prognosis keselamatan janin pada persalinan pervaginam adalah buruk.

\section{Solusio Plasenta}

Solusio Plasenta adalah lepasnya plasenta (placental abruption) dari tempat implantasinya pada korpus uteri sebelum bayi lahir. Dapat terjadi pada setiap saat dalam kehamilan. Terlepasnya plasenta dapat sebagian (parsialis) atau seluruhnya (totalis) atau hanya rupture tepinya (rupture sinus marginalis).

Tanda dan gejala terjadinya solusio plasenta adalah sebagai berikut :

a. Perdarahan pervaginam berwarna merah kehitaman

b. Mungkin juga tidak tampak perdarahan karena darah tidak keluar melalui ostium, tetapi menumpuk di retroplasenta. Selain itu, jika ada perdarahan yang keluar, jumlah perdarahan yang tampak bukan merupakan gambaran sesungguhnya jumlah perdarahan yang terjadi. 
c. Rasa nyeri/mules yang terus-menerus karena uterus berkontraksi dan tegang

d. Dapat disertai gawat janin sampai kematian janin.

Diagnosis solusio plasenta dibuat berdasarkan hal-hal berikut ini :

a. Anamnesis riwayat perdarahan per vaginam (tidak menggambarkan beratnya solusio, hati-hati karena mungkin juga tidak ada tanda perdarahan), nyeri dan mules terus menerus (menjadi tanda.kecurigaan utama), gerakan janin dirasakan berkurang atau menghilang.

b. Pemeriksaan fisik : keadaan umum dapat baik sampai buruk (syok), uterus tegang terus menerus, nyeri tekan pada uterus serta denyut jantung janin bradikardia atau menghilang

c. Jika memungkinkan periksa konfirmasi USG perhatikan perdarahan retroplasenta.

Penatalaksanaan solusio plasenta adalah sebagai berikut :

PRINSIP : mencegah kematian ibu, menghentikan sumber perdarahan, jika janin masih hidup, mempertahankan dan mengusahakan janin lahir hdup .

a. Optimalisasi keadaan umum ibu : transfuse darah, infus

b. Terminasi kehamila : persalinan segera, pervaginam atau bila perlu per abdominal (SC). Diharapkan dapat menyelamatkan nyawa janin dan dengan lahirnya plasenta, diharapkan dapat menghentikan perdarahan. Namun jika diputuskan dilakukan SC, maka tidak perlu menunggu sampai darah tersedia karena tindakan terbaik sesungguhnya adalah menghentikan perdarahan. 
c. Untuk mengurangi tekanan intrauterine yang dapat menyebabkan nekrosis ginjal (reflex utero-renal), selaput ketuban segera dipecahkan, meskipun belum tentu persalinan akan dilakukan pervaginam.

Prognosis

Prognosis ibu tergantung dari hal-hal sebagai beriktu

a. Luas daerah plasenta yang mengalami solusio

b. Jumlah perdarahan

c. Derajat gangguan hemostatis yang terjadi

d. Ada tidaknya factor pemberat lain (preeklamsia, infeksi )

e. Waktu antara terjadinya solusio plasenta dengan pengeluaran isi uterus.

Prognosis bayi tergantung dari hal-hal berikut ini

a. Keadaan pada saat ditegakkan diagnosis solusio sebagian besar janin meninggal dalam waktu yang sangat cepat

b. Jika janin masih hidup tergantung waktu antara terjadinya solusio dengan pengeluaran/persalinan

c. Ada tidaknya fasilitas/kemampuan resusitasi dan perawatan intensif yang baik pascapersalinan.

\section{Tanda- tanda dini bahaya/komplikasi ibu da janin masa kehamilan lanjut}

Komplikasi pada ibu dan janin masa kehamilan lanjut :

1. Perdarahan pervaginam

2. Sakit kepala yang hebat

3. Penglihatan kabur

4. Bengkak di wajah dan jari tangan 
5. Keluar cairan pervaginma

6. Sakit kepala yang hebat

7. Gerakan janin tidak terasa

8. Nyeri perut yang hebat 


\section{BAB VIII \\ PENDOKUMENTASIAN ASUHAN KEHAMILAN}

\section{A. Pendahuluan}

1. Deskripsi Singkat

Pada sesi perkuliahan ini membahas tentang pendokumentasian asuhan kebidanan meliputi model-model dokumentasi asuhan, prinsip dokumentasi dan aspek legal dokumentasi. Pembahasan ini menguraikan secara jelas tentang macam-macam asuhan kebidanan yang pada umumnya dipakai dalam mendokumentasikan hasil asuhan kebidanan yang diberikan pada pasien/klien.

2. Tujuan Instruksional Khusus

Setelah menyelesaikan materi ini, mahasiswa mampu melakukan pendokumentasian asuhan.

\section{B. Konsep Dokumentasi}

1. Pengertian

Dokumentasi adalah suatu proses pencatatan, penyimpanan informasi data, fakta yang bermakna dalam pelaksanaan kegiatan.

Dokumentasi kebidanan adalah suatu sistem pencatatan dan pelaporan informasi tentang kondisi dan perkembangan kesehatan pasiendan semua kegiatan yang dilakukan oleh petugas kesehatan.

2. Tujuan dan Manfaat Pendokumentasian

Dokumentasi merupakan aspek penting dalam melaksanakan asuhan kebidanan. Semua instansi kesehtan memilih dokumentasi pasien yang dirawat walaupun bentuk formulir masing-masing 
intasnsi berbeda. Tujuan dokumentasi asuhan pada pasien/klien adalah :

a. Menjamin tertibnya administrasi dalam rangka upaya peningkatan pelayanan di instansi pelayanan

b. Sebagai bahan untuk mempertanggungjawabkan tindakan yang dilakukan pada psien/klien

c. Bila terjadi gugatan hukum maka dokumentasi kebidanan dapat membantu

Manfaat dokumentasi asuhan pada pasien/klien dapat dirasakan oleh pasien, dokter, perawat, bidan, riset dan tenaga kesehatan lainnya.

\section{Model-Model Dokumentasi Asuhan}

1. SOR (Source Orientasi Record)

Model ini menempatkan catatan atas disiplin orang atau sumber yang mengelola pencatatan. Bagian penerimaan klien mempunyai lembar isian tersendiri, dokter menggunakan lembar untuk mencatat intruksi, lembaran riwayat penyakit dan perkembangan penyakit, perawat menggunakan catatan masing-masing.

Catatan beriorentasi pada sumber terdiri dari dari lima komponen yaitu :

a. Lembar order dokter

b. Lembar riwayat medik/penyakit

c. Catatan perawatan

d. Catatan dan laporan kasus

Keuntungan penggunaan SOR :

a. Menyajikan data yang secara berurutan dan mudah diidentifikasi 
b. Memudahkan perawat untuk secara bebas mengetahui bagaimana informasi akan dicatat

c. Format dapat menyederhanakn proses pencatatan masalah kejadian, perubahan, intervensi dan respon klien atau hasil Kerugian penggunaan SOR :

a. Potensial terjadinya pengumpulan data yang terfragmentasi karena tidak berdasarkan urutan waktu

b. Kadang-kadang mengalami kesulitan untuk mencari data sebelumnya tanpa harus mengulang pada awal

c. Superficial pencatatan tanpa data yang jelas

d. Memerlukan pegkajian data dari berbagai sumber untuk menentukan masalah dan tindakan yang akan dilakukan pada klien

e. Waktu pemberian asuhan memerlukan waktu yang banyak

f. Data yang berurutan mungkin menyulitkan dalam interprtasi/analisa

g. Perkembangan klien susah dimonitor

2. POR (Problem Orientasi record)

Model ini memusatkan data tentang klien didokumentasikan dan disusun menurut masalah klien. Sistem dokumentasi jenis ini mengintegrasikan semua data mengenai masalah yang dikumpulkan oleh dokter, perawat, bidan atau tenaga kesehatan lain yang terlibat dalam pemberian pelayanan kepada klien.

Model dokumentasi ini terdiri dari empat komponen yaitu :
a. Data dasar
b. Daftar masalah 
c. Evaluasi dan penyelesaian masalah secara jelas dicatat

d. Daftar awal rencana asuhan

e. Catatan perkembangan (progres notes)

Keuntungan penggunaan POR :

a. Lebih menekankan pada masalah klien

b. Pencatatan tentang kontinuitas dari asuhan

c. Data disusun berdasarkan masalah yang spesifik

d. Daftar masalah akan membantu mengingatkan petugas untuk perhatian

e. Daftar yang perlu diintervensi, dijabarkan dalam rencana tindakan Kerugian penggunaan POR :

a. Penekanan hanya pada masalah, penyakit dan ketidakmampuan sehingga mendekatkan pada pengobatan

b. Kemungkinan adanya kesulitan jika daftar masalah belum dilakukan timbul masalah baru

c. Dapat menimbulkan pengulangan yang tidak perlu

3. CBE (Chatting By Exception)

Adalah sistem dokumentasi yang hanya mencatat secara naratif dari hasil atau penemuan yang menyimpang adri keadaan normal atau standar.

Keuntungan penggunaan $\mathrm{CBE}$ :

a. Mengurangi penggunaan waktu untuk mencatat sehingga banyak waktu yang digunakan untuk melaksanakan asuhan

b. Tersusunnya standar minimal untuk pengkajian dan intevensi

c. Data yang tidak normal nampak jelas

d. Data yang normal secara mudah dapat ditandai dan dipahami 
e. Data normal atau respon diharapkan tidak mengganggu informasi lain

f. Menghemat waktu karena catatan rutin dan observasi tidak perlu dilakukan

g. Pencatatan duplikasi dapat dikurangi

h. Data klien dicatat pada format secepatnya

i. Informasi terbaru dapat diletakkan pada tempat tidur klien

j. Jumlah halaman lebih sedikit digunakan dalam dokumentasi

k. Rencana tindakan disimpan sebagai catatan yang permanen Kerugian penggunaan CBE :

a. Pencatatan seacara narasi, sangat singkat, dan sangat tergantung dengan cheklist

b. Kemungkinan ada pencatatan yang masih kosong atau tidak

c. Pencatatan rutin sering diabaikan

d. Adanya pencatatan kejadian yang tidak semuanya didokumentasi

4. PIE (Problem Intervention and Evaivaffin)

Keuntungan penggunaan PIE :

a. Rencana tindakan dan catatan perkembangan dapat dihubungkan

b. Memungkinkan pemberian asuhan yang kontinue karena secara jelas

c. Perkembangan klien mulai dari masuk sampai pulang dapat dengan mudah digambarkan

d. Dapat diadaptasi untuk catatan yang otomatis

Kerugian penggunaan PIE :

a. Tidak dapat digunakan untuk pencatatan semua disiplin ilmu 
b. Pembatasan rencana tindakan yang tidak diaplikasikan untuk beberapa situasi keperawatan kebidanan.

\section{Manajemen Varney}

Merupakan metode pemecahan masalah kesehatan ibu dan anak yang khusus dilakukan oleh bidan didalam memberikan asuhan kebidanan kepada individu, keluarga, kelompok dan masyarakat. Dalam proses penatalakasanaan asuhan menurut Varney ada 7 langkah meliputi :

\section{Langkah I : Tahapan Pengumpulan Data Dasar}

Pada langkah pertama ini di lakukan pengkajian dengan mengumpulkan semua data / informasi yang akurat dan lengkap dari semua sumber yang berkaitan dengan kondisi klien. Untuk memperoleh data di lakukan dengan cara yaitu :

a. Anamnese. Dilakukan untuk mendapatkan biodata, riwayat menstruasi, riwayat kesehatan, riwayat kehamilan, persalinan dan nifas, bio-psiko-sosial-spritual, serta pengetahauan kilen.

b. Pemeriksaan fisik. Sesuai dengan kebutuhan dan pemeriksaan tanda- tanda vital, meliputi :

1) Pemeriksaan khusus (inspeksi, palpasi, auskultasi dan perkusi).

2) Pemeriksaan penunjang (laboratorium, dan catatan terbaru serta catatan sebelumnya).

\section{Langkah II : Intersprestasi Data Dasar}

Pada langkah ini di lakukan identifikasi yang benar terhadap diagnosa atau masalah dan kebutuhan klien berdasarkan interprestasi yang benar atas dasar data-data yang telah di kumpulkan. 
Diangnosa kebidanan adalah suatu kesimpulan yang di tegakkan oleh bidan berdasarkan data subjektif dan data objektif sesuai wewenang, lingkup praktek kebidanan.

Masalah kebidanan adalah suatu kesimpulan yang ditegakkan oleh bidan berdasarkan data subjektif dan data objektif tentang halhal yang berkaitan dengan pengalaman klien yang ditemukan dari hasil pengkajian atau yang menyertai diagnosa.

Kebutuhan adalah hal-hal yang di butuhkan oleh klien dan belum teridentifikasih dalam diagnosa dan masalah yang di dapatkan dengan melakukan analisa data.

3. Langkah III : Mengidentifikasi Diagnosa Atau Masalah Potensial dan Mengantisipasinya.

Pada langkah ini kita mengidentifikasi masalah atau diagnosa potensial lain berdasarkan rangkaian masalah dan diagnosa yang telah di identifikasi. Langkah ini membutuhkan antisipasi, bila memungkinkan di lakukan pencegahan. Bidan diharapkan dapat waspada dan bersiap-siap mencegah diagnosis atau masalah potensial ini menjadi benar-benar terjadi. Langkah ini penting sekali dalam melakukan asuhan yang aman.

Pada langkah ketiga ini bidan di tuntut untuk mempu mengantisipasi masalah potensial tidak hanya merumuskan masalah potensial yang akan terjadi tetapi juga merumuskan tindakan antisipasi agar masalah atau diagnosis potensial tidak terjadi. Sehingga langkah ini benar merupakan langkah yang bersifat antisipasi yang rasional atau logis. Kaji ulang apakah diagnosis atau masalah potensial yang diidentifikasih sudah tepat. 
4.Langkah IV : Mengidentifikasi \& Menetapkan Kebutuhan yang Memerlukan Penanganan Segera Untuk Melakukan Konsultasi, Kolaborasi Dengan Tenaga Kesehatan Lain Berdasarkan Kondisi Klien.

Bidan mengidentifikasi perlunya bidan atau dokter melakukan konsultasi atau penaganan segera bersama anggota tim kesehatan lain sesuai dengan kondisi klien. Langkah ke empat mencerminkan kesinambungan proses manejemen kebidanan. Kegiatan bidan pada tahap ini adalah konsultasi, kolaborasi, dan melakukan rujukan.

5. Langkah V : Menyusun Rencana Asuhan Yang Menyeluruh

Pada langkah ini di lakukan perencanaan yang menyeluruh, di tentukan langkah-langkah sebelumnya. Langkah ini merupakan kelanjutan manajeman terhadap diagnosa masalah yang telah diidentifikasih atau di antisipasi, pada langkah ini informasi/ data dasar yang tidak lengkap dapat di lengkapi.

6. Langkah VI : Melaksanakan Langsung Asuhan Dengan Efisien Dan Aman

Pada langkah ke enam rencana asuhan menyeluruh seperti yang telah di uraiakan pada langkah ke lima dilaksanakan secara efisien dan aman. Perencanaan ini bisa di lakukan seluruhnya oleh bidan atau sebagian lagi oleh klien atau anggota tim kesehatan lainnya. Walau bidan tidak melakukannya sendiri, ia tetap memikul tanggung jawab untuk mengarahkan pelaksanaanya, misalnya memastikan langkah-langkah tersebut benar-benar terlaksana.

Dalam situasi dimana bidan berkolaborasi dengan dokter untuk menangani klien yang mengalami komplikasih, maka keterlibatan 
manajemen asuhan bagi klien adalah tetap bertanggung jawab terhadap telaksananya rencana asuhan bersama yang menyeluruh tersebut. Manajemen yang efisien akan menyangkut waktu dan biaya serta meningkatkan mutu dan asuhan klien. Kaji ulang apakah semua rencana asuhan telah di laksanakan.

\section{Langkah VII : Mengevaluasi}

Pada langkah ini di lakukan keefektifan dari asuhan yang sudah di berikan meliputi pemenuhan kebutuhan akan bantuan apakah benar-benar telah terpenuhi sesuai dengan kebutuhan sebagaimana telah di identifikasih di dalam masalah dan diagnosa. Rencana tersebut dapat dianggap efektif jika memang benar efektif dalam pelaksanaanya.

Ada kemungkinan bahwa sebagian rencana tersebut efektif sedangkan sebagian belum efektif mengingat bahwa proses manajemen asuhan ini merupakan suatu kegiatan yang berkesinambungan maka perlu mengulang kembali dari awal setiap asuahan yang tidak efektif melalui manajemen untuk mengidentifikasi mengapa proses manajemen tidak efektif serta melakukan penyesuaian terhadap rencana asuhan tersebut.

\section{E. SOAP}

Tujuh langkah Varney di saringkan menjdi 4 langkah, yaitu SOAP (Subjektif, Objektif, Analisa dan Penatalaksanaan). SOAP di saringkan dari proses pemikiran penatalaksaan kebidanan sebagai perkembangan catatan kemajuan keadaan klien.

1.S : Subjektif 
Mengambarkan pendokumentasian hasil pengumpulan data klien melalui anamnesis sebagai langkah I Varne

\section{O : Objektif}

Mengambarkan pendokumentasian hasil pengumpulan data dari pemeriksaan umum, pemeriksaan fisik, dan pemeriksaan penunjang sebagai langkah I Varney.

3. A : Analisa

Mengambarkan pendokumentasian hasil analisa yaitu ibu hamil dengan hiperemesis gravidarum 2, 3, 4 Varney.

\section{P : Penatalaksaaan}

Penatalaksanaan mencatat seluruh perencanaan dan penatalaksanaan yang telah di lakukan seperti tindakan antisipasi, tindakan segera, tindakan secara komprehensif, penyuluhan, dukungan, kolaborasi, evaluasi/follow up dari rujukan sebagai langkah 5, 6, dan 7 Varney

Dalam rangka mengevaluasi perkembangan/kemajuan klien dapat dilakukan dengan cara pengamatan (observasi) interaksi antara bidan dank lien serta keluarga dan anggota tim yang lain (wawancara). Manajemen kebidanan merupakan metode/bentuk pendekatan yang digunakan bidan dalam memberikan asuhan kebidanan di mana bidan harus membuat suatu catatan perkembangan dari kondisi pasien untuk dapat memecahkan masalah. Catatamn perkembangan terkadang dalam bentuk kertas polos tanpa kolom. Catatan ini kemudian lebih dikenal dengan metode SOAP (IER) yang berfungsi sebagai panduan untuk menampilkan informasi tentang pasien atau juga disebut sebagai SOAP 
notes yang kemudian di modifikasi secara individual menjadi metode SOAPIE,SOAPIER, SOAPIED.

SOAP adalah cara mencatat informasi tentang pasien yang berhubungan dengan masalah pasien yang terdapat pada catatan kebidanan. Konsep SOAP adalah sebagai berikut:

S catatan yang berhubungan dengan masalah dari sudut pandang pasien. Ekspresi pasien mengenai kekhawatiran dan keluhannya dicatat sebagai kutipan langsung atu ringkasan yang berhubungan dengan diagnosis (data subjektif). Pada orang yang bisu dibagian data dibelakang S dan diberi tanad "Nol" atau "X", sedangkan pada bayi atau anak kecil data subjektif ini dapat diperoleh dari orang tua. Dapat subjektif ini dapat digunakan untuk menguatkan diagnosis yang akan dibuat.

O Data ini memberi bukti gejala klinis pasien dan fakta yang berhubungan dengan diagnosis. Data fisiologis, hasil observasi yang jujur, informasi kajian teknologi (hasil laboratorium, sinar X,rekaman CTG, USG) dapat digolongkan penting dari diagnosis yang akan ditegakkan.

A Analisis atau assessment pengakajian yaitu masalah atau diagnosis yang ditegakkan berdasarkan data atau informasi subjektif dan objektif yang dikumpulkan dan disimpulkan. Oleh karena keadaan pasien terus berubah dan selalu ada informasi baru baik subjektif dan objektif serta sering diungkapkan secara terpisah-pisah, maka proses pengkajian adalah sesuatu yang penting dalam mengikuti perkembangan pasien dan menjamin suatu perubahan baru cepat 


\begin{tabular}{|l|l|}
\hline & $\begin{array}{l}\text { diketahui dan dapat diikuti sehingga dapat diambil tindakan yang } \\
\text { tepat. }\end{array}$ \\
\hline $\mathrm{P}$ & $\begin{array}{l}\text { Plan/Planning/Perencanaan atau Penatalaksanaan yaitu membuat } \\
\text { rencana tindakan saat itu atau yang akan dating ini untuk } \\
\text { mengusahakan mencapai kondisi pasien sebaik mungkin atau } \\
\text { menjaga/mempertahankan kesejahteraannya. Proses ini termasuk } \\
\text { kriteria tujuan tertentu dari kebutuhan pasien yang harus dicapai } \\
\text { dalam batas waktu tertentu. Tindakan yang diambil harus } \\
\text { membantu pasien mancapai kemajuan dalam kesehatan dan/atau } \\
\text { proses persalinannya serta harus mendukung rencana dokter apabila } \\
\text { rencana tindakan tersebut dalam manajemen kolaborasi atau } \\
\text { rujukan. }\end{array}$ \\
\hline
\end{tabular}

\section{SOAPIE}

S.O.A.P sama dengan diatas, ditambah dengan :

I : Intervensi /implementasi yaitu pelaksanaan rencana tindakan untuk mengatasi masalah, keluhan atau mencapai tujuan pasien (persalinan). Tindakan ini harus disetujui oleh pasien kecuali bila tidak dilaksanakan akan membahayakn keselamatan pasien. Oleh karena itu, pilihan pilihan pasien harus sebanyak mungkin menjadi bagian dari proses ini. Apabila kondisi pasien berubah, intervensi mugnkin juga harus berubah atau disesuaikan

E : Evaluasi yaitu tafsiran dari efek tentang tindakan yang telah diambil. Hal ini penting untuk menilai keefktifan asuhan yang diberikan. Analisis dari hasil yang dicapai focus dari penilaian kecepatan tindakan. Apabila kriteria tujuan tidak tercapai, proses 
evaluasi dapat menjadi dasar untuk mengembangkan tindakan alternative sehingga dapat mencapai tujuan.

\section{SOAPIER}

S.O.A.P.I.E sama dengan diatas, ditambah dengan :

$\mathbf{R}$; Revisi atau perbaikan, dimana komponen evaluasi dapat menjadi suatu petunjuk perlunya perbaikan dari perubahan dan tindakan atau menunjukkan perubahan dari rencana awal atau perlunya suatu kolaborasi baru atau rujukan.

\section{SOAPIED}

S.O.A.P.I.E sama dengan diatas ditambah dengan

D : Dokumenteasi.

\section{F. Prinsip Dokumentasi}

Beberapa prinsip etik yang berhubungan dengan pendokumentasian asuhan sebagai berikut :

1. Autonomy

Merupakan suatu hal dimna kita menghargai hak-hak orang, memberikan hak-hak mereka untuk membuat pertimbangan dan pilihan tindakan. Prinsip autonomy mendasari secara legal terhadap informed consent sebelum memerintahkan, penolakan ataupun pengobatan privacy dan rahasia dalam akses untuk catatan.

2. Beneficence

Merupakan tugas hubungan sesama yang baik untuk saling menolong mereka dan membuat mereka lebih interes agar tidak terjadi kesalahan.

3. Justice 
Memberikan penyaluran kebenaran terhadap manfaat dan pokokpokok komunitas.

4. Fidelity

Merupakan kesetiaan dimana termasuk masalah-masalah yang sebenarnya. Kepercayaan dan pemeliharaan sumpah. Prinsip ini mendasari respek dalam hubungan dengan petugas-pasien.

5. Reliability

Yaitu kemampuan mengapresiasikan data yang ada, contoh :

a. Bidan dapat mencatat apa yang bisa dicatat

b. Bidan akan mengatur apa yang bisa di ukur

Untuk mengapresiasikan data yang ada, seorang bidan harus melakukan tindakan-tindakan secara terstruktur dan sistematis sehingga dapat memperoleh informasi yang sejelas-jelasnya mengenai keadaan/kondisi pasien, serta tindakan-tindakan medis yang telah dilakukan perencanaan tindakan medis selanjutnya.

6. Validity

Yaitu keakuratan. Bidan menjelaskan sesuai dengan keadaan yang sebenarnya. Keakuran data dapat diperoleh apabila seorang tenaga medis berpedoman pada prinsip-prinsip berikut ini :

a. Akurasi

Yaitu mendeteksi nilai atau sumber data yang ada

b. Presesi

Yaitu pengukuran data kembali harus sama dengan pengukuran data sebelumnya

c. Validitas eksternal 
Yaitu sampel harus sesuai dengan karakteristik data populasi yang kita teliti

d. Validitas internal

Yaitu kemampuan dan keahlian orang yang melakukan tugas, serta sensitivitas dari data diagnostic/alat lanoratorium.

\section{G. Aspek Legal Dokumentasi}

Panduan legal sebagai petunjuk cara mendokumentasikan dengan benar sebagai berikut :

1. Jangan menghapus, menggunakan tipex atau mencoret tulisan yang salah ketika mencatat karena akan tampak seakan-akan petugas mencoba menyembunyikan informasi atau merusak catatan. Cara yang paling benar adalah dengan membuat suatu garis pada tulisan yang salah, tulis kata "salah" lalu diparaf, kemudian tulis catatan yang benar.

2. Jangan menulis komentar yang bersifat mengkritik klien atau tenaga kesehatan yang lain, karena pernyataan tersebut dapat dipergunakan sebgai bukti perilaku tidak profesional atau askeb yang tidak bermutu.

3. Koreksi semua kesalahan sesegera mungkin karena kesalahan menulis dapat diikuti dengan kesalahan tindakan. Jadi jangan tergesa-gesa melengkapi catatan, pastikan informasi akurat.

4. Catat hanya fakta, catatan harus akurat dan dapat dipercaya. Pastikan apa yang tertulis adalah fakta, jangan berspekulasi atau hanya menulis perkiraan saja.

5. Jangan biarkan bagian kososng pada catatan petugas karena orang lain dapat menambahkan informasi yang tidak benar pada bagian 
kosong tersebut. Baut garis horizontal pada sepanjang bagian kosong dan paraf dibagian bawahnya.

6. Semua catatan harus dapat dibaca dan tulis dengan tinta karena tulisan yang tidak terbaca bisa disalahartikan sehingga menimbulkan kesalahan dan dapat dituntut dipengadilan.

7. Jika anda mempertanyakan suatu instruksi catat bahwa anda sedang mengklarifikasi, karena kita petugas melakukan tindakan yang diketahui tidak benar dapat dituntut karena bertindak sebagai dokter.

8. Tulis untuk diri sendiri karena petugas kesehatan bertanggung jawab atas informasi yang ditulis, jadi jangan menulis untuk orang lain.

9. Hindari penggunaan tulisan yang bersifat umum karena informasi yang spesifik tentang kondisi klien atau kasus bisa secara tidak sengaja terhapus jika informasi bersifat terlalu umum. Oleh karena itu tulis lengkap, singkat dan padat.

10. Mulai dokumentasi dengan waktu dan akhir dengan tanda tangan dan titel. Pastikan urutan kejadian dicatat dengan benar dan tanda tangan menunjukkan orang yang bertanggungjawab atas dokumentasi tersebut. Jangan tunggu sampai akhir giliran dinas untuk mencatat perubahan penting yang terjadi beberapa jam yang lalu. 


\section{BIOGRAFI}

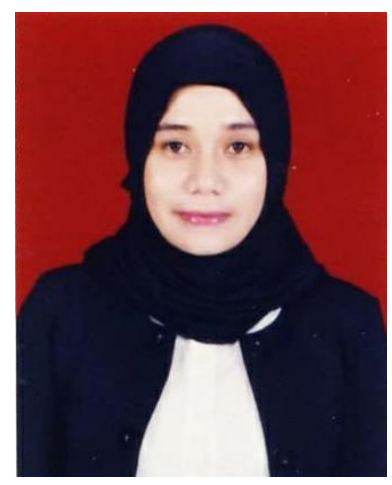

Hatijar S.ST.,M.Kes,lahir di Waulai 15 Juli 1984. Penulis lulus D3 Kebidanan pada tahun 2011 kemudian melanjutkan pendidikan D4 Kebidanan dan pada tahun 2015 lulus S2 Kesehatan Masyarakat Konsentrasi Kesehatan reproduksi . Pada tahun 2012-2016 penulis bekerja sebagai staff dan pengajar di program studi D3 Kebidanan UIT Makassar dan sekarang penulis mengajar di STIKES Husada Mandiri Poso Mulai tahun 2017 sampai dengan sekarang. Penulis selalu terbuka atas saran dan kritikan yang diberikan kepada penulis dan dijadikan sebagai motivasi dalam penulisan buku ajar ini. Penulisan buku ini adalah atas dukungan dari orang tua dan orang terdekat yang dipersembahkan untuk para pembaca khusunya mahasiswa kebidanan. 


\section{BIOGRAFI}

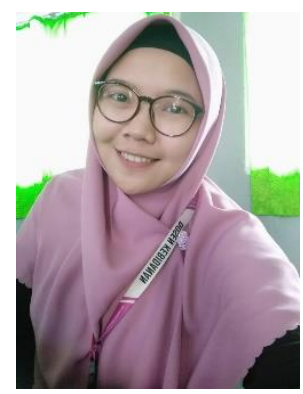

Lilis Candra Yanti S.ST.,M.Keb lahir di Attapange 17 agustus 1989. Penulis menyelesaikan Pendidikan D3 di Universitas Indonesia Timur Makassar kemudian pada tahun 2012 penulis melanjutkan Pendidikan d4 Kebidanan Stikes Mega Rezky Makassar dan pada tahun 2017 lulus S2 Kebidanan di Universitas Hasanuddin Makassar. Pada tahun 2011-2012 penulis bekerja sebagai bidan pelaksanan di salah satu BPS di Makassar dan pada tahun 2013 sampai dengan sekarang aktif mengajar di Program Studi D3 Kebidanan STIKES Husada Mandiri Poso dan pada tahun 2017 sampai sekarang menjabat ketua program studi d3 Kebidanan Stikes Husada Mandiri Poso.

\section{BIOGRAFI}

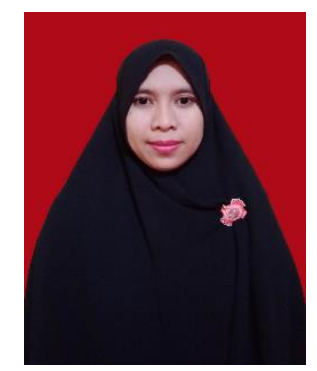

Irma Suryani Saleh S.ST.,M.Kes, lahir di pare-pare • Penulis menyelesaikan pendidikan D3, D4 Kebidanan dan S2 Kesehatan di Universitas Indonesia Timur Makassar. Tahun 2010 -2017 penulis mengajar di prodi D3 Kebidanan UIT Makassar dan pada tahun 2018 ssampai dengan sekarang aktif mengajar di akbid Madani Sinjai. 